\title{
Republican mothers of and above their time: Abigail Adams and Theodosia Burr Alston
}

Joanna Lyn Reynolds

West Virginia University

Follow this and additional works at: https://researchrepository.wvu.edu/etd

\section{Recommended Citation}

Reynolds, Joanna Lyn, "Republican mothers of and above their time: Abigail Adams and Theodosia Burr Alston" (2008). Graduate Theses, Dissertations, and Problem Reports. 787.

https://researchrepository.wvu.edu/etd/787

This Thesis is protected by copyright and/or related rights. It has been brought to you by the The Research Repository @ WVU with permission from the rights-holder(s). You are free to use this Thesis in any way that is permitted by the copyright and related rights legislation that applies to your use. For other uses you must obtain permission from the rights-holder(s) directly, unless additional rights are indicated by a Creative Commons license in the record and/ or on the work itself. This Thesis has been accepted for inclusion in WVU Graduate Theses, Dissertations, and Problem Reports collection by an authorized administrator of The Research Repository @ WVU. For more information, please contact researchrepository@mail.wvu.edu. 


\title{
Republican Mothers of and above Their Time:
} Abigail Adams and Theodosia Burr Alston

\section{Joanna Lyn Reynolds}

\author{
Thesis submitted to the \\ Eberly College of Arts and Sciences \\ at West Virginia University \\ in partial fulfillment of the requirements \\ for the degree of
}

\author{
Master of Arts \\ in \\ History
}

\author{
Mary Lou Lustig, Ph.D., Chair \\ Ken Fones-Wolf, Ph.D. \\ Katherine Aaslestad, Ph.D. \\ Department of History
}

\section{Morgantown, West Virginia 2008}

Keywords: Republican Mother, Abigail Adams, Theodosia Burr Alston Copyright 2008 Joanna Lyn Reynolds 


\section{ABSTRACT \\ Republican Mothers of and above Their Time: Abigail Adams and Theodosia Burr Alston}

\section{Joanna Lyn Reynolds}

Unique in their time, Abigail Adams and Theodosia Burr Alston possessed intellectual accomplishments, social prominence, and economic status. Also, both women enjoyed supportive marriages with influential husbands as well as proximity to leading male figures of the Revolution and the new nation. Yet, similar to other women of their era, Abigail Adams and Theodosia Burr Alston nurtured their children's educational and moral development, supported their husbands' public service, and kept informed about current events. While marked differences in lifestyle, geographic environment, familial dynamics, and the public and political affiliations of their male family members distinguished them from each other, as Republican Mothers, they contributed to the success of the republican experiment.

The American Revolution, with its emphasis on virtue and public service, and Enlightenment philosophy, with its emphasis on reason and the perfectibility of the individual, gave birth to a new female ideal: the Republican Mother. Though this specific term would not be coined for two centuries, during the era of the American Revolution and the new Republic, contemporary writers, philosophers, and political and religious leaders espoused the tenets of the ideal. While this new image of women still implied the domestic role as a woman's most important and proper position in her society, it also underscored the need for better educated women. Specifically, society entrusted women with instilling virtue, disinterested service, and patriotism in their children-especially the male children, who would become the Republic's future leaders.

In addition to gaining education for the sake of becoming effective teachers of future leaders, women needed to become capable of managing business affairs in the absence of men, who might be called at any moment into public service. The conviction of contributing service to the nation found a pronounced emphasis in the Revolutionary era. As legacies of Puritanism, duty and public service resonated just as strong in late eighteenth-century America as in previous generations. Although a generation separated Abigail Adams and Theodosia Burr Alston, they became extraordinary examples of Republican Mothers. 


\section{DEDICATION}

To my mother, Judy Reynolds, and Dr. Mary Lou Lustig, often my second mother away from home - two of the best examples of virtuous, invested, and selfless mothers a woman could hope to be. 


\section{ACKNOWLEDGEMENTS}

From the beginning of my undergraduate studies at WVU, Dr. Mary Lou Lustig encouraged me and spent countless hours advising me and reading drafts of seminar papers. When I pursued graduate work, she patiently guided my thesis through countless proposals, research questions, chapters, and revisions. Dr. Lustig gave me the confidence to persist with my studies and my thesis. Not only is Dr. Lustig a fascinating professor, dedicated historian, and exceptional writer, but she is genuinely concerned and invested in students' development and general well-being. I am eternally grateful that I was lucky enough to be one of her students.

In addition to Dr. Lustig, my committee members, Dr. Ken Fones-Wolf and Dr. Katherine Aaslestad, provided insight, valuable feedback, and encouragement. I enjoyed several of Dr. Fones-Wolf's and Dr. Aaslestad's courses at WVU, and my writing and research skills improved due to their influence. I appreciated their patience throughout this long process in light of their busy teaching, research, and family obligations.

At WVU, Dr. Lustig, Dr. Ken Fones-Wolf, Dr. Aaslestad, and Dr. Elizabeth Fones-Wolf were my primary professors during my undergraduate and graduate studies. I thank them for creating comfortable, professional, and intriguing classroom environments and for always unknowingly offering a positive perspective, grain of advice, and word of encouragement when it was needed most. Furthermore, I am grateful to the staff of the WVU Libraries system, particularly the Wise Library staff, who were so helpful in facilitating countless interlibrary loans and assisting me with my research.

My family has supported me through every test, paper, presentation, project, challenge, and success. Often, they accompanied me on research trips and stayed up late with me as I studied or worked on papers. They always expressed an interest in my work

and never gave up on me in the more difficult times. I owe everything I have achieved to their love and support. 


\section{TABLE OF CONTENTS}

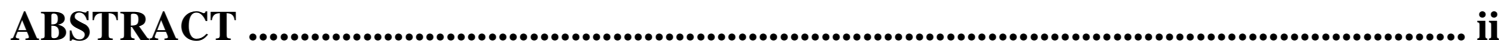

DEDICATION......................................................................................................... iii

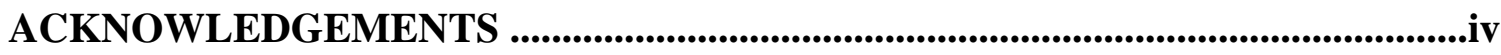

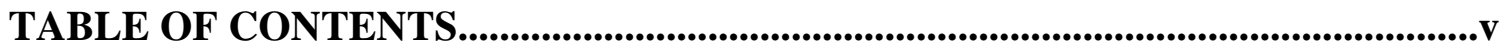

INTRODUCTION

CHAPTER ONE: ABIGAIL ADAMS ...................................................................23

The Emergence of Republican Motherhood

CHAPTER TWO: THEODOSIA BURR ALSTON ...............................................64

Republican Motherhood and Education in the Next Generation

CHAPTER THREE: ABIGAIL ADAMS............................................................107

Legacies and Lessons of Republican Motherhood

CHAPTER FOUR: THEODOSIA BURR ALSTON..............................................135

Legacies and Lessons of Republican Motherhood

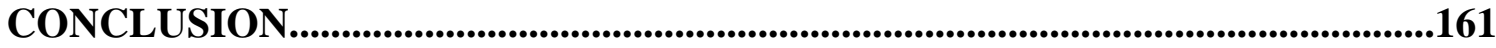

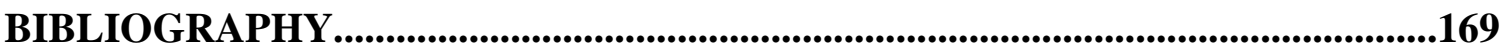




\section{Introduction}

Abigail Adams (1744-1818) experienced firsthand the birth of the new independent nation while Theodosia Burr Alston (1783-1813) witnessed the formation of the new Republic. Unique to other women of their time, Abigail Adams and Theodosia Burr Alston lived much of their lives in urban environments and circulated in the most prominent social and political spheres of their day. Both women flourished intellectually, encouraged by the men closest to them. Accordingly, they gained the respect of society and exercised a considerable personal and professional influence upon their husbands and sons.

While Abigail Adams and Theodosia Burr Alston differed from most other women, they also represented thousands of women in their respective generations who exemplified the values, dispositions, and duties associated with Republican Motherhood. Modern historians, notably Linda K. Kerber and Mary Beth Norton, invented the historical construct of Republican Motherhood to describe the unique station assigned to women in the new nation. Specifically,

"Private virtue became a public good. Political theory merged public virtue (the ability to do what was good for the society as a whole) with private virtue.... By modeling and teaching virtue, women could influence their sons and husbands to be good public citizens." ${ }^{1}$

The theory was that "a successful republic...required virtuous families... [and] women, in their maternal capacity, would ensure the existence of the virtuous families.”2

\footnotetext{
${ }^{1}$ Joan R. Gunderson, To Be Useful to the World: Women in Revolutionary America, 1740-1790 (New York: Twayne Publishers, 1996), 147.

${ }^{2}$ Mary Beth Norton, “The Evolution of White Women’s Experience in Early America,” The American Historical Review, vol. 89, no. 3 (June 1984), 618.
} 
Moreover, women needed to educate their sons about the values of republicanism,

liberty, and honor and encourage their husbands' public service in order to guarantee the permanency of the American Republic. Thus,

"Women had the power to direct the moral development of the male citizens of the Republic. The influence women had on children, especially sons, gave them ultimate responsibility for the future of the nation.”3

\section{Republican Motherhood and Women's Education}

"The solidity and stability of the liberties of your country rest with You.... While you thus keep our country virtuous, you maintain its independence and ensure its prosperity. [Your] honor, delicacy, modesty, elegance of wit,...true politeness,...[and] a sense of religion... [qualify] you to lay a foundation in the mind of a youth and raise the noblest superstructure.... [Instill] habits that will ripen into excellence...[and] inspire him when grown up with magnanimity, and enable him to acquire true renown; that will conduct him invariably in the paths of undisguised [honor], of truth, of virtue, and religion; that will make him the stay and support of his aged parents, the boast of his country, and the glory of humanity."4

Following the American Revolution, many contemporary authors, philosophers, and public leaders charged women with the responsibilities highlighted in this 1795 commencement speech. The success of the American republican experiment depended not only on the courageous heroics of Patriot soldiers and brilliant statesmen, but also on the efforts of educated, virtuous women. Republican Motherhood served an important role in this respect.

The American Revolution, with its emphasis on virtue and public service, and Enlightenment philosophy, with its emphasis on reason and the perfectibility of the

\footnotetext{
${ }^{3}$ Linda K. Kerber, Women of the Republic: Intellect \& Ideology in Revolutionary America (Chapel Hill: The University of North Carolina Press, 1980), 229.

${ }^{4}$ No author known, "Female Influence: Being the Substance of an Oration delivered at the Annual Commencement of Columbia College," New York Magazine, or Literary Repository (May 6, 1795), 304305.
} 
individual, gave birth to Republican Motherhood. While this new ideal image of women still implied the domestic role as a woman's most important and proper position in her society, it also underscored the need for better educated women who would bring forth the Republic’s future leaders. The Republican Mother “was dedicated to the service of civic virtue: she educated her sons for it, she condemned and corrected her husband's lapses from it."5

To justify the creation of new female academies and seminaries, education reformers claimed that "the education of young women had traditionally been an education for marriage....Girls were said to need a new kind of education because their traditional training had been superficial.”6 Although female education received greater attention and support than in previous decades, this subject still provoked controversy. Specifically,

"The difficulty [in promoting female education] was caused when a female tried to go beyond the knowledge appropriate to her sex, for then she risked becoming that universal object of ridicule and reproach, a 'learned lady.,",7

Republican Motherhood helped to alleviate the controversy over women’s education. “The Republican Mother was an educated woman who could be spared the criticism normally addressed to the Learned Lady because she placed her learning at her family’s service.” ${ }^{8}$ In Europe, women faced similar challenges to educational progress.

\footnotetext{
${ }^{5}$ Linda K. Kerber, Women of the Republic, 229.

${ }^{6}$ Ibid, 203.

${ }^{7}$ Mary Beth Norton, Liberty's Daughters: The Revolutionary Experience of American Women, 1750-1800 (Boston: Little, Brown, and Company, 1980), 264.

${ }^{8}$ Linda K. Kerber, Women of the Republic, 228.
} 
“Women’s opportunities changed in the public sphere. A new, compelling cultural emphasis on family and motherhood for the female half of the population meant that they could not be represented as intellectuals."9

Consequently, on both sides of the Atlantic, learning for learning's sake would not

become an acceptable impetus for education until many generations later.

\section{Contemporary Views of the Female Intellect}

“It was generally held that women's minds were inferior to men's minds-or at least different from them. The usual reasons for educating women did not include making great scholars or artists of them, but only making them fit company for men and capable of educating their children in rudimentary literacy."10

As society barred women from public leadership, political participation, and scholastic achievement, domesticity provided the only acceptable occupation for women. Many contemporary men and women scorned those few women who pursued advanced education, particularly classical knowledge and other "masculine” subjects, for abandoning their civic duty and prescribed boundaries. Enlightenment philosopher JeanJacques Rousseau condemned any inclusion of women into the public sector. He wrote that providing a public place for women led to a "civic promiscuity which throughout confounds the two sexes in the same employments and in the same labors and which cannot fail to engender the most intolerable abuses.”"11

\footnotetext{
${ }^{9}$ Ulrike Gleixner and Marion W. Gray, eds, Gender in Transition: Discourse and Practice in GermanSpeaking Europe, 1750-1830 (Ann Arbor: The University of Michigan Press, 2006), 4.

${ }^{10}$ Margaret Hunt, et al., eds., Women and the Enlightenment (New York: The Haworth Press, Inc., 1984), 25.

${ }^{11}$ Jean-Jacques Rousseau in Allan Bloom, ed, Emile, or On Education (New York: Basic Books, Inc., Publishers, 1979), 363. This quote from Rousseau's Emile, published in 1762, alludes to an important notion, which often prevailed in eighteenth-century society. In this excerpt, Rousseau discusses Plato, who "in his Republic...gives women the same exercises as men.” Rousseau comments, "I can well believe it! Having removed private families from his regime and no longer knowing what to do with women, he found himself forced to make them men.” Ibid, 362. What is significant about this passage is Rousseau's scorn for women who participate in the public sector because by doing so, they assume masculine roles and
} 
Numerous contemporary observers aligned with Jean-Jacques Rousseau's

delineation of the proper male and female roles and his belief that when the two roles

became “confounded,” as he wrote, “civic promiscuity” resulted. Rousseau elaborated,

"Woman's empire is an empire of gentleness, skill, and obligingness; her orders are caresses, her threats are tears. She ought to reign in the home as a minister does in a state-by getting herself commanded to do what she wants to do.... But when she fails to recognize the voice of the head of the house, when she wants to usurp his rights and be in command herself, the result of this disorder is never anything but misery, scandal, and dishonor."12

In a popular contemporary advice manual, A Father's Legacy to His Daughters, Dr. John

Gregory echoed Rousseau’s sentiments. Writing about the ideal characteristics a woman

should embody, Gregory explained that

"modesty, which I think so essential in your sex, will naturally dispose you to be rather silent in company, especially in a large one.... One may take a share in conversation without uttering a syllable. The expression in the countenance (shows) it, and this never escapes an observing eye....Wit is the most dangerous talent you can possess. It must be guarded with great discretion and good nature, otherwise it will create you many enemies....Wit is so flattering to vanity, that they who possess it become intoxicated, and lose all self-command."13

qualities. This theme often appeared in contemporary writings by men who disagreed with advancing women's intellect and for the primary goal of attaining knowledge and refinement. Men in line with Rousseau's thinking generally supported the education of women for the sole purpose of making women better wives and mothers. Ironically, many women used the same logic in demanding better education for themselves and their peers. Mary Wollstonecraft, while certainly not in line with Rousseau's thoughts on women, argued in A Vindication of the Rights of Woman (1792), "Make women rational creatures, and free citizens, and they will quickly become good wives, and mothers - that is-if men do not neglect the duties of husbands and fathers." See Carol H. Poston, ed, A Vindication of the Rights of Woman with Strictures on Political and Moral Subjects (New York: W.W. Norton and Co., Inc., 1975; first published in London by J. Johnson, 1792), 178.

12 Jean-Jacques Rousseau in Bloom, ed, Emile, 408.

${ }^{13}$ Dr. John Gregory, A Father's Legacy to His Daughters 2d ed (London: W. Straham, T. Cadell, J. Balfour, W. Creech, 1774), 28, 30. 
In contemporary literature, writers often equated "wit” with advanced education and portrayed this characteristic as an unbecoming trait. James Fordyce further described how unpleasant “wit” or advanced learning could make a man’s home.

"Men who understand the science of domestic happiness know that its very first principle is ease.... We are never safe in the company of a critic; and almost every wit is a critic by profession. In such company we are never at liberty to unbend ourselves. All must be the straining of study, or the anxiety of apprehension: how painful! Where the heart may not expand and open itself with freedom, farewell to real friendship, farewell to convivial delight! But to suffer this restraint at home, what misery!”14

Concentrating on this same theme, Jean-Jacques Rousseau contended that

"a brilliant wife is a plague to her husband, her children, her friends, her [servants], everyone. From the sublime elevation of her fair genius, she disdains all her woman's duties and...[makes] herself into a man.... Outside her home she is always ridiculous and very justly criticized; this is the inevitable result as soon as one leaves one's station and is not fit for the station one wants to adopt. All these women of great talent never impress anyone but fools." 15

Similar in principle to Rousseau, James Fordyce echoed the traditional claim about education unsexing women. He wrote, "I do not wish to see [the female world] abound with metaphysicians, historians, speculative philosophers, or Learned Ladies of any kind. I should be afraid, lest the sex should [lose] its softness."16 Furthermore, Reverend John Bennet explained that 'politics, philosophy, mathematics, or metaphysics....would render [females] unwomanly indeed' and 'damp that vivacity, and

\footnotetext{
${ }^{14}$ Ibid, 87.

${ }^{15}$ Jean-Jacques Rousseau, in Bloom, ed, Emile, 409.

${ }^{16}$ James Fordyce, Sermons to Young Women (Dublin: W. Gilbert, 1796), 91. This work was first published in 1766.
} 
destroy that disengaged ease and softness, which are the very essence of [the female] graces. ${ }^{\prime 17}$

Hannah More, a popular contemporary author and essayist wrote several widelyread treatises conveying guidelines for appropriate manners, pastimes, and goals expected of women. In 1777, More posited that women possessed different capabilities of intellect than men. Specifically, she predicted,

"[Pretensions] to that strength of intellect, which is requisite to penetrate into the [abstruser] walks of literature, it is presumed [women] will readily relinquish.... The lofty epic, the pointed Satire, and the more daring and successful flights of the Tragic Muse, seem reserved for the bold adventurers of the other sex." ${ }^{\text {"18 }}$

In 1813, More returned to the subject of the acceptable sphere for women's education.

She contended that women should pursue

"more sober studies, which, not having display for their object, may make [them] wise without vanity, happy without witnesses, and content without panegyrists; the exercise of which will not bring celebrity, but improve usefulness." ${ }^{\text {19 }}$

Thus, these contemporary authors believed that intellectual rigor, exemplified or pursued by women, contraindicated utility and distracted them from their conventional duties. Such writers also threatened the discouragement of potential husbands as ammunition in their arsenal to convince women to avoid becoming "learned." One

\footnotetext{
${ }^{17}$ As quoted in Norton, Liberty's Daughters, 263.

${ }^{18}$ Hannah More, Essays on Various Subjects, Principally Designed for Young Ladies (London: J. Wilkie and T. Cadell, 1777), 6-7.

${ }^{19}$ Hannah More, Strictures on the Modern System of Female Education, 2 vols (New York: George Long, 1813),I: 3. The idea that too much education precluded women's “usefulness" was not a new argument against female education. Writing in 1673, Bathshua Makin, though an advocate of female learning, displayed the traditional assumption that education only prepared one for public work, which was certainly not an accepted venue for women. Makin included a letter from an acquaintance in his essay, and this acquaintance stated, "Women do not much desire knowledge; they are of low parts, soft feeble natures, they have other things to do [and] they will not mind if they be once bookish. The end of learning is to fit one for public employment, which women are not capable of....They will abuse their education, and be so intolerably proud, there will be no living with them." Bathshua Makin, An Essay to Revive the [Ancient] Education of Gentlewomen (London: J. D., 1673), 6.
} 
significant female author recognized this point nearly 100 years before Republican Motherhood supported female education. John Locke’s close friend and esteemed thinker, Lady Damaris Masham wrote Occasional Thoughts in Reference to a [Virtuous] or Christian Life in 1694 and published it in the early 1700s. Lady Masham conceded that most men of her day did not relish intelligence in a woman. However, she argued,

"I may, I suppose, without any injurious reflection upon ladies, presume, that if men did usually find woman the more amiable for being knowing, they would much more commonly, than now...be so." 20

Several essays in the popular early eighteenth century publications of Richard Steele and Joseph Addison's The Tatler and The Spectator substantiated Lady Masham's argument that women might value education if men accordingly valued it in them.

Spectator essay 534 identifies a young woman who related,

"Our House is frequented by Men of Sense, and I love to ask Questions when I fall into such conversation; but I am cut short with something or other about my bright Eyes. There is...a Language particular for talking to women in; and none but those of the very first good Breeding (who are very few, and seldom come into my Way) can speak to us without regard to our Sex."21

In Tatler essay 141, a father hopes to send his nine-year-old daughter to a boarding school. However, his wife opposed the measure and told him, "She is too much a woman, and understands the formalities of visiting and tea table so very nicely, that none, [though] much older, can exceed her.,"22 Obviously, this woman saw no need for further education since her daughter already mastered the essential and expected attributes of

\footnotetext{
${ }^{20}$ Lady Damaris Masham, Occasional Thoughts in Reference to a [Virtuous] or Christian Life (London: A. and J. Churchill, 1705), 197, 203-204.

${ }^{21}$ Joseph Addison and Richard Steele, Essay \# 534, November 12, 1712, The Spectator in 8 vols (London: H. Baldwin, 1797), VII: 337.

${ }^{22}$ Richard Steele, Essay \#141, March 1, 1709, The Tatler, Lubrications of Isaac Bickerstaff in 2 vols (London: John Morphew, 1711), I: 330.
} 
gentility. Emphatically, Richard Steele discounted the mother's reasoning and responded to the father in Tatler essay 248. Steele wrote, "It is with great indignation that I see such crowds of the female world lost to human society, and condemned to laziness, which makes life pass away with less relish than in the hardest [labor].,23

In line with James Fordyce's belief that men are "never safe in the company of a critic," who would assuredly bring "misery" to the home, contemporary essayist “Alphonzo" unabashedly admitted that this "misery” might stem from insecurities. Writing in the American Magazine in 1788, “Alphonzo" explained,

"I believe observation will confirm my conjecture, that a strong attachment to books in a lady often deters a man from approaching her with the offer of his heart. This is ascribed to the pride of our sex." ${ }^{24}$

Incidentally, neither Abigail Smith’s nor Theodosia Burr's suitors were deterred by their intelligence. By the time she was nineteen, Abigail Smith was engaged to John Adams, and at the same age, Theodosia Burr Alston was a married mother. The men in Abigail and Theodosia's lives felt no hesitation whatsoever in "approaching [them] with the offer of [their] heart[s]."

\section{An Intellectual Foundation for Republican Motherhood}

Aaron Burr stayed up an entire night deeply engrossed in a new book. The United States Senator from New York found in Mary Wollstonecraft's seminal 1792 work, Vindication of the Rights of Woman, a blueprint for his hopeful ambition to counter the prevalent stereotypes of the female intellect. Burr found his impetus in Wollstonecraft's

\footnotetext{
${ }^{23}$ Richard Steele, Essay \#248, November 8, 1710, Ibid, II: 554.

24 “Alphonzo,” “An Address to the Ladies,” American Magazine, vol 1, issue 4 (New York: March 18, 1788), 244.
} 
assertion that because women possess "an immortal soul," then women "must have, as the employment of life, an understanding to improve." ${ }^{25}$ Wollstonecraft argued, "Reason is...the simple power of improvement; or...of discerning truth...but the nature of reason must be the same in all, if it be an emanation of divinity."26

Having defended women's innate rational capabilities, Wollstonecraft laid the foundations for female education reform.

"To render women truly useful members of society, I argue that they should be led, by having their understandings cultivated on a large scale, to acquire a rational affection for their country, founded on knowledge, because it is obvious that we are little interested about what we do not understand.... [Private] duties are never properly fulfilled unless the understanding enlarges the heart; and that public virtue is only an aggregate of private.,27

Expanding on how women were to become "useful members of society," Wollstonecraft cautioned that neglecting the development of women's rational capacities could lead to catastrophe of morals in society. She warned,

"Make [women] free, and they will quickly become wise and virtuous, as men become more so; for the improvement must be mutual, or the injustice which one-half of the human race are obliged to submit to [will destroy] the virtue of men [and it] will be worm-eaten."28

As a result, the corruption of society's virtue would lead to disastrous effects upon the future generation of the Republic's leaders. Wollstonecraft maintained,

"As the rearing of children, that is, the laying a foundation of sound health both of body and mind in the rising generation, has justly been insisted on as the peculiar destination of woman, the ignorance that incapacitates them must be contrary to the order

\footnotetext{
${ }^{25}$ Mary Wollstonecraft in Poston, ed, Vindication, 63.

${ }^{26}$ Ibid, 53.

${ }^{27}$ Ibid,, 191-192.

${ }^{28}$ Ibid, 175.
} 
of things. And I contend that their minds can take in much more, and ought to do so, or they will never become sensible mothers." 29

Wollstonecraft's ideas arrived in America just at the moment when the public paid more attention to women's place in a new Republic. Yet, traditional assumptions of a starkly defined separate sphere and accompanying stereotypes of the inferiority of women’s characteristics and abilities remained deeply ingrained in American society. In her Vindication, Wollstonecraft directed many of her arguments at refuting Jean-Jacques Rousseau's theories on education and the sexes.

While both Aaron Burr and Mary Wollstonecraft admired Jean-Jacques Rousseau's model of education in his Emile, Rousseau never intended his model for a female pupil. He argued,

“The first education of men depends on the care of women. Men's morals, their passions, their tastes, their pleasures, their very happiness also depends on women. Thus, the whole education of woman ought to relate to men. To please men, to be useful to them, to make herself loved and honored by them, to raise them when young, to care for them when grown, to counsel them, to console them, to make their lives agreeable and sweet." 30

Rousseau assigned a preeminent value to feminine charms, and he further questioned,

"Is it our fault that [women] please us when they are pretty, that their mincing ways seduce us, that the art which they learn from [their mothers] attracts us and pleases us, that we like to see them tastefully dressed...?So, decide to raise them like men. The men will gladly consent to it! The more women want to resemble [men], the less women will govern [men], and then men will truly be the masters!”31

Wollstonecraft, however, contended that if women were not educated, they could not fulfill their domestic role.

\footnotetext{
${ }^{29}$ Ibid, 189.

${ }^{30}$ Jean-Jacques Rousseau, in Bloom, ed, Emile, 365.

${ }^{31}$ Ibid, 363.
} 
"If children are to be educated to understand the true principle of patriotism, their mother must be a patriot; and the love of mankind from which an orderly train of virtues spring, can only be produced by considering the moral and civil interest of mankind., 32

Mary Wollstonecraft presented a formidable challenge for opponents of female education in the line of Jean-Jacques Rousseau. Certainly, she won the argument over whether women deserved an education based on rational capabilities. Also, she played successfully upon the fears of those who feared for the permanence of the American Republic by warning of the precarious stability of a society in which women remained uninformed. Most importantly, she invoked the Republican Mother ideal by calling for the education of patriot mothers as necessary for the nurturing of patriot children and virtuous mothers for virtuous children.

\section{Economic and Social Implications of Republican Motherhood}

Republican Motherhood required more than gaining education for the sake of becoming effective teachers of future leaders. Women must become capable of managing business affairs in the absence of men, who might be called at any moment into public service. Abigail Adams could serve as the model of this important aspect of Republican Motherhood. In performing the duties attendant on a proxy of a husbandfather-farmer-manager, “Abigail Adams became...the breadwinner in a single-parent household.... [However,] Abigail considered her unaccustomed work as patriotic service to her nation.”33

\footnotetext{
${ }^{32}$ Mary Wollstonecraft in Poston, ed, Vindication, 4.

${ }^{33}$ Edith B. Gelles, First Thoughts: Life and Letters of Abigail Adams (New York: Twayne Publishers, 1998), 24.
} 
Public service was expected of men during the Revolutionary era and was one of the legacies of Puritanism. In America, as in Europe, women were not encouraged to pursue public avocations but society celebrated women who acted in place of an absent male.

"[As] early as the mid-eighteenth century, women of the German-speaking world met ridicule and exclusion when they gained public attention by publishing their work. They could achieve status, however, by presenting themselves as dutiful assistants or apprentices to their husbands and fathers. ${ }^{34}$

Women's experiences during the American Revolution spanned a wide continuum of intensity. To some women, the Revolution may have been a distant conflict heard about only through comments of husbands or fathers or read about in newspapers. Other women, however, had enemy troops at their front doors for long periods, as was true in Boston. ${ }^{35}$ In addition to the presence of troops, women in all of the former American colonies faced economic problems including inflation, currency depreciation, food and labor shortages, and devastation of property, businesses, and livestock. Although they stepped out of their traditional sphere in times of necessity, Abigail Adams

"and other women of her class accepted the notion that while they were mentally equal to men, their sphere of activity was entirely private in nature, except on those occasions when they substituted for their absent husbands. ${ }^{, 36}$

\footnotetext{
${ }^{34}$ Gleixner and Gray, eds, 3.

${ }^{35}$ Lynne Withey, Dearest Friend: A Life of Abigail Adams (New York: Simon \& Schuster, 1981), 77.

${ }^{36}$ Joan Hoff Wilson, “The Illusion of Change: Women and the American Revolution,” in Alfred F. Young, ed, The American Revolution: Explorations in the History of American Radicalism (Dekalb, IL: Northern Illinois University Press, 1976), 428.
} 
Substituting in the absence of husbands, fathers, and sons embodied the popular pre-Revolutionary era ideal of woman as the "help-meet." Cotton Mather, writing in the late seventeenth century, encouraged women to master

"all the Affairs of Housewifery... as well as...[Arithmetic] and [Accounting], and such other Arts relating to Business, as may enable her to do the Man whom she may hereafter have, Good and not Evil all the Days of her Life."37

Though Mather's advice pre-dated Abigail Adams’ birth by approximately fifty years, his ideal of the "help-meet" resonated throughout later generations. Advice magazines and pamphlets as well as public figures emphasized women’s duty to assist their husbands and/or other male family members in the maintenance and stability of the family home, farm, and possibly, business.

For example, Dr. Benjamin Rush, popular physician, writer, educational reformer, and a contemporary and friend of many of leading politicians (including both John Adams and Aaron Burr), supported the "help-meet" ideal in one of his most noted speeches. At the same time that he advocated the "help-meet," he also encouraged improved female education. In 1787, Rush addressed the administration, faculty, and students of the Young Ladies’ Academy in Philadelphia, and his remarks soon appeared in a popular pamphlet. Rush proposed teaching females "geography...chronology...history, biography, and travels...astronomy, natural philosophy," and a strong foundation in "the

\footnotetext{
${ }^{37}$ Cotton Mather, Ornaments for the Daughters of Zion, or the Character and Happiness of a Virtuous Woman in a Discourse (New York: Scholar's Facsimiles \& Reprints, 1978), 5. Mather's original publication of Ornaments was in 1692. Incidentally, in the introduction to Mather's pamphlet, editor Pattie Cowell argued that Ornaments' "three editions-1692, 1694, 1741 - testify to its popularity." Further, she related, "George Whitefield, for example, noted in his journal entry for October 20, 1740, that he recommended the book 'to all, especially the Boston ladies."” As quoted in Ibid, xii. Whitefield's journal entry is excerpted from George Whitefield, Journals: 1737-41 (Gainesville, FL: Scholars’ Facsimiles \& Reprints, 1969), 479.
} 
English language.” Moreover, he advocated including "figures and bookkeeping” in their curriculum. He explained,

"There are certain occupations in which [women] may assist [their husbands] with this knowledge; and should [a woman] survive [her husband], and agreeably to the custom of the country be the executrix of his will, she cannot fail of receiving immense advantages from it." 38

\section{Historiography and the Emergence of Republican Motherhood}

Cotton Mather’s "help-meet” ideal represented the typical lifestyle for white women in colonial America. Most families lived in rural environments where they worked the land and relied upon both men's and women's contributions to the household. Colonial women's days included

"[making] the fire, coaxing a blaze, setting dough to rise, baking bread, and boiling meat. In between [they] turned to the most pressing tasks that varied by season: dairying..., gathering eggs and feeding chickens, brewing cider or beer, slaughtering, smoking bacon, or managing her vegetable garden. [They] sewed clothes and quilts for the family.... [They] spent hours boiling laundry and later ironing clothes with heavy irons heated on the fire., ${ }^{39}$

In general, “[women's] skills were acquired in the daily rounds of activities in the household, the family business, and the marketplace." ${ }^{40}$

The Great Awakening of the 1740s marked a transition point for many women in the American colonies. The emphasis on individual experience and emotion in spiritual conversion attracted many females to evangelical religion. Religious leaders of the Great Awakening believed that female emotions such as "affection, nurture, and piety

\footnotetext{
${ }^{38}$ Benjamin Rush, Thoughts upon Female Education, accommodated to the Present State of Society, Manners, and Government, in the United States of America, Addressed to the Visitors of the Young Ladies' Academy in Philadelphia, 28 July 1787, at the Close of the Quarterly Examination (Boston: Samuel Hall, 1787), 8-9.

${ }^{39}$ Sara M. Evans, Born for Liberty: A History of Women in America (New York: The Free Press, 1989), 28. ${ }^{40}$ Ibid.
} 
represented the emotions that provided social glue rather than social disruption."41 As more and more women experienced conversion, “[women] became a majority of churchgoers just as churches moved from the center to the margins of colonial political life.”42 Furthermore, religious leaders assigned women with the responsibility for nurturing virtue, charity, and piety in society. Thus, religion impacted perceptions of women’s proper role.

"[Earlier] Protestant understandings of spirituality [emphasized that] Eve was Adam's 'help-meet,' made like him in the 'image of God,' both had sinned, though Eve's was the more grievous. Now...Eve became a ravishing beauty, object of Adam's adoration. The detectable shift 'from a harmony built upon sameness to a harmony built upon difference'...established women's body and soul as a distinct and different creation of God."43

Along with the Great Awakening, the American Revolution affected gender roles. The era of the American Revolution made politics bigger, not only in the United States, but in Europe as well. During the Revolution, Americans became more cognizant than ever of the meanings behind such flashpoint terms as freedom, liberty, and citizenship. Even though removed from the public practice of politics, women on both continents actively discussed, witnessed, and experienced the changes of their generations. Indeed, “Women, although excluded from the discourse of history, experienced historical change."44

\footnotetext{
${ }^{41}$ Ibid, 42.

${ }^{42}$ Ibid, 40.

${ }^{43}$ Ibid, 41.

${ }^{44}$ Gleixner and Gray, eds, 5.
} 
Although American colonists actively supported liberty from tyranny, liberty in practice in the United States applied only to (white) male citizens who could vote and participate in the governance of a new Republic. Republican Motherhood provided a specific responsibility for women in the new Republic.

"The problem of female citizenship...was solved by endowing domesticity itself with a political meaning. The result was the idea and image of the republican mother. Her patriotic duty to educate her sons to be moral and virtuous citizens linked her to the state and gave her some degree of power over its future." Furthermore, "now women had a civic role and identity distinct from men, a role essential to the state's welfare." It was "understood that public virtue... depended entirely on the private virtue of individuals, and it was to women they entrusted the nurturance of these virtues."

Just as the American Revolution widened the divide between gender roles in America, the Enlightenment and French Revolution highlighted the disparities between the sexes in Europe. Significantly,

"During the transitional era 1750-1830, the European gender system underwent a significant series of transformations....Modernity, however, was founded on the idea of equality, discussed as a universal maxim but applied only to white male citizens.... Although women [during the French Revolution] played essential roles in the revolutionary process...they were among the revolution's disenfranchised. They remained excluded from political participation in civil society." ${ }^{46}$

In addition to the Great Awakening and the American Revolution, changing patterns of the household and economics led to a sharper delineation of the values ascribed to and expected of men and women. Furthermore, economic shifts affected notions of the public and private realms of home and business. The emergence of such shifts in the late eighteenth century changed how women would be expected to contribute to the new Republic.

\footnotetext{
${ }^{45}$ Evans, 57.

${ }^{46}$ Gleixner and Gray, eds, 1-2.
} 
"By 1790 middle and upper-class families made the home a place of retreat and nurture....Industry linked work to public spaces in order to separate it from the domestic duties of women. Men developed a public life and world, while women cultivated a network of female friends in the private garden of the home." ${ }^{\text {,47 }}$

In effect, as economic modernization increasingly identified work as outside of the home, the home received a more private and domestic connotation. Notably, this gradual process of economic modernization first affected the middling and upper sorts in urban areas. These individuals gained more access into law, business, finance, medicine, academia, and politics, which comprised most of the professions sought outside of the home and farm. Wholesale economic modernization still loomed several decades in the future for most Americans.

Yet, for middle-to-upper-class women, like Abigail Adams and Theodosia Burr Alston, whose fathers, husbands, and sons entered a more public world of work, a sense of 'separate spheres,' accompanied these changes. These spheres implied inherently different expectations of the sexes.

"Home...was... a bastion of peace, of orderliness, of unwavering devotion to people and principles beyond the self. Here the woman of the family, and the children would pass most of their hours and days - safe from the grinding pressures and dark temptations of the world at large; here, too, the man of the family would retreat periodically for repose, renewal, and inner fortification against the dangers he encountered elsewhere.... [The] husband-father undertook an exclusive responsibility for productive labor.... in one or another setting well removed from the home-hearth, in offices, factories, shops, or wherever.",48

\footnotetext{
${ }^{47}$ Gunderson, 132.

${ }^{48}$ John Demos, Past, Present, and Personal: The Family and the Life Course in American History (Oxford: Oxford University Press, 1986), 31-33.
} 
As American Republican Motherhood encouraged improvements in female education, a changing awareness of women's roles in Europe during this time also led to long-term efforts for reform of female education and status in general. Specifically,

"In the educated middle-class, the new polarized gender roles did not necessarily lead to master-servant relationships; such roles could also establish teacher-student relationships, which, in turn, could become more companionable through shared concerns and mutual attractions of the partners. Middle-class women learned letter-writing and literary interpretations from their husbands and within two generations demanded professional education.... Nineteenth-century women enjoyed little empowerment in their own right; however, when fathers and husbands conferred rights and offered participatory roles, women could take on responsibilities that transcended the domestic realm., 49

Abigail Adams and Theodosia Burr Alston conveyed many of the traits illustrated in this description of European trends in the late eighteenth century. Both women enjoyed companionate marriages, and they also benefited from valuable "teacher-student relationships" not only with their husbands and fathers, but other distinguished persons of their generations.

Due to their familiarity with and access to important public figures, Abigail Adams and Theodosia Burr Alston wrote voluminous letters to a multitude of interesting male and female correspondents. Through the mostly private but occasionally public medium of letters, women such as Abigail Adams and Theodosia Burr Alston expressed their opinions, sought assistance, gained information about their family members’ involvement in important matters, and improved their knowledge about domestic, economic, and foreign affairs. Letter-writing for women compared with the public press for men as a medium for exchange of ideas, opinions, frustrations, and knowledge.

\footnotetext{
${ }^{49}$ Gleixner and Gray, eds, 17-18.
} 


\section{Republican Motherhood Incarnate: Abigail Adams and Theodosia Burr Alston}

Abigail Adams embodied Republican Motherhood by a willingness to sacrifice her personal happiness and comfort in the turbulent and tenuous hours of the early American nation. She served as the sole confidante, adviser, and conscience of her husband as he progressed from delegate to the Continental Congresses, envoy to the Netherlands and France, ambassador to Great Britain, first Vice-President, and second President of the United States. John Adams placed atypical trust in her intellectual and managerial qualities, and she became the manager of the family farm and financial interests during his years of public service.

Although Abigail Adams never experienced the systematic curriculum that Aaron Burr envisioned and Theodosia Burr pursued, John Adams appreciated and encouraged his wife's intensive reading. In turn, Abigail enjoyed sharing her opinions of events and ideas with John, and her literary pursuits included newspapers, political pamphlets, and contemporary poets and philosophers. Furthermore, Abigail accompanied her voracious reading with an equal intensity of writing. She carried on extensive correspondences with a multitude of esteemed political and social contemporaries, male and female.

As she maintained the stability of their home and brilliantly reigned in her domestic sphere, Abigail Adams reared her children, and most notably her eldest son, John Quincy Adams, to value the virtuous principles of republicanism. Her influence upon John Quincy led him to a path of public service, spanning the majority of his life. He achieved the ultimate pinnacle envisioned by any Republican Mother when he became the sixth President of the United States in 1824. 
Theodosia Burr Alston embodied Republican Motherhood by excelling in intellectual areas usually reserved for men but remaining committed to her domestic duties. Her father, inspired by Mary Wollstonecraft's Vindication, provided young Theodosia with a sound, progressive, and ungendered education. Aaron Burr vowed, "I hope yet by her, to convince the world...that women have souls."50 Following her marriage and in spite of suffering recurrent afflictions from an irreparable injury in childbirth, Theodosia avidly pursued intellectual improvement. She recognized her important role in mentoring her only child, Aaron Burr Alston (Gamp), much like her parents mentored her. She actively supervised Gamp’s education, and she fervently supported the ambitions and careers of her father and husband.

Because of her renowned family lineage and especially, her father's public positions, Theodosia Burr Alston corresponded and socialized with respected medical professionals, philosophers, politicians, artists, and foreign dignitaries. At a young age, she exhibited advanced maturity and poise in her role as her father's official hostess in New York. Her reputation and demeanor as a polished, composed, and intelligent woman impressed many spectators at Burr's treason trial in Richmond. Moreover, in view of her many eminent acquaintances, Theodosia felt no qualms in directly seeking their assistance during her father's darkest hours. Though often afflicted with physical pain and external adversity, Theodosia Burr Alston remained committed to her duties as a mother, wife of a prominent Charleston citizen, and daughter of a well-known public figure.

${ }^{50}$ Aaron Burr to Theodosia Prevost Burr, February 8, 1793, Matthew L. Davis, ed, Memoirs of Aaron Burr with Miscellaneous Selections from his Correspondence (Memoirs), 2 vols (New York: Harper \& Brothers, 1836), I: 362. 
While their influence reigned within the domestic circle, Abigail Adams and Theodosia Burr Alston also enjoyed considerable respect in the public sector. Despite the fact that some contemporaries scorned any close contact between women and public affairs, "Republican Motherhood altered the female domain in which most women had always lived out their lives; it justified women's absorption and participation in the civic culture.”51 Both Abigail Adams and Theodosia Burr Alston actively discussed women’s status, enjoyed and advocated companionate marriages, experienced the changing awareness of women's domestic status, and acted within the public and private.

Although a generation separated Abigail Adams and Theodosia Burr Alston, they became extraordinary examples of intellectual accomplishment and social poise in their respective eras. Equipped with impressive intellects, virtuous characters, confidence, and fortitude, Abigail and Theodosia "[educated] [their] [children] and [served] as a model for other women...[contributing] to the growth of knowledge — to the spread of liberty— which was essential in a modern republic., 52

\footnotetext{
${ }^{51}$ Linda K. Kerber, Women of the Republic, 284.

${ }^{52}$ Nancy Isenberg, Fallen Founder: The Life of Aaron Burr (New York: Viking Penguin, 2007), 81.
} 


\section{Chapter One: Abigail Adams The Emergence of Republican Motherhood}

"Improve your understanding for acquiring [useful] knowledge and virtue, such as will render you an ornament to society, an [Honor] to your Country, and a Blessing to your parents. Great Learning and superior abilities, should you ever possess them, will be of little value and small Estimation, unless Virtue, [Honor], Truth and [integrity] are added to them. Adhere to those religious Sentiments and [principles] which were early instilled into your mind and remember that you are accountable to your Maker for all your words and actions.... Dear as you are to me, I had much rather you should have found your Grave in the ocean you have crossed, or any untimely death crop you in your Infant years, rather than see you an Immoral profligate or a Graceless child."53

In June of 1778, Abigail Adams instructed her ten-year-old son, John Quincy

Adams to abide by these principles while he lived abroad. John Quincy accompanied his father, John Adams, a newly-appointed member of the American diplomatic delegation in France, to Europe the previous spring. By June 1778, John and John Quincy had been living in France for four months, and Abigail sat at her Braintree, Massachusetts table lamenting their absence amidst a period of war in America, economic difficulties close to home, and anxiety over the activities, well-being, and future of her family.

The encouragement of a ten-year-old boy to aspire to become 'an ornament to society,' with 'great learning and superior abilities' may seem a bit overbearing or premature. However, in the context of that particular generation and especially, in the context of that particular family, Abigail's advice perfectly accorded with the expectations for the eldest son of one of the leading Patriots of the American Revolution. Abigail's advice to her son perfectly aligned with the expectations for a son of John and Abigail Adams.

\footnotetext{
53 Abigail Adams to John Quincy Adams, June [10], 1778, L. H. Butterfield, ed, Adams Family Correspondence (AFC), 8 vols (Cambridge: The Belknap Press of Harvard University Press, 1963-2007), III: 37.
} 
Abigail Adams, minister's daughter, close relative to prominent members of the Massachusetts' upper-class, and wife of an accomplished attorney-turned-politician, possessed her own unique array of qualities. These talents attached her to her relatives and friends and impressed many notable figures of the founding and later generations. Some historians identify Abigail Adams as a "quintessential Puritan" and "the leading woman of the American Revolution." ${ }^{54}$ Abigail's Puritan virtues defined her as "purposeful, pietistic, passionate, prudish, frugal, diligent, courageous, well-educated, and self-righteous." ${ }^{55}$ These traits appear in various scenes of her rich life, yet merely offer glimpse of the complex, often troubled, but always fascinating Abigail Adams.

\section{Youth, Education, and a 'Companionate’ Marriage}

Born in Weymouth, Massachusetts in 1744, Abigail Smith was the daughter of Harvard graduate Reverend William Smith and Elizabeth Quincy Smith. Abigail had three siblings, older sister, Mary, younger brother, William, and younger sister, Elizabeth (“Betsy”). Abigail’s maternal grandparents, John and Elizabeth Quincy, lived nearby at Mount Wollaston, and her grandfather John Quincy was a wealthy leader of his community. Similarly, her paternal relatives included "prosperous...merchants with branches in South Carolina and the West Indies.”56

Abigail's parents, grandparents, close relatives, and family friends paid much attention to Abigail's education. However, she never attended school, mostly due to her

\footnotetext{
${ }^{54}$ Ralph Ketcham, “The Puritan Ethic in the Revolutionary Era: Abigail Adams and Thomas Jefferson,” in Carol V. R. George, ed, 'Remember the Ladies': New Perspectives on Women in American History (Syracuse, NY: Syracuse University Press, 1975), 49-50.

${ }^{55}$ Ibid, 49.

${ }^{56}$ Charles W. Akers, Abigail Adams: An American Woman, $2^{\text {nd }}$ ed (New York: Longman, 2000), 2-3.
} 
frequent childhood illnesses and her mother's fears for her health. ${ }^{57}$ Nonetheless, Abigail's father provided his three daughters with uninhibited access to his impressive library. During their adolescence, the girls profited from the company and guidance of Richard Cranch, a scholar who eventually married Mary.

Richard Cranch “introduced [Abigail] to the poetry of Milton, Pope, and Thomson, to Shakespeare and to the novels of Samuel Richardson,” as well as a "“small acquaintance’ with the French language.”58 Abigail Smith read voraciously as a young girl, and she continued this practice throughout her life. Thus, her appreciation for Richard Cranch’s willingness to support her progress never waned. In her later years, “Abigail still recalled her debt to this gifted man:

'To our dear and venerable Brother Cranch do I attribute my early taste for letters; and for the nurture and cultivation of those qualities which have since afforded me much pleasure and satisfaction. He it was who put proper [Books] into my hands, who taught me to love the Poets and to distinguish their [Merits].",59

Cultivating her love of books and engaging her in intellectual discussions contributed to her gratitude for Richard Cranch. Yet, it was another, more personal contribution for which she would be infinitely indebted to Cranch for the happiness of her life and for subsequent benefits. On one of Richard Cranch’s many visits to the Smith home, he brought along a young Braintree, Massachusetts attorney, John Adams. Though first impressions are often prescient, history may be thankful that John's first impression of Abigail Smith was anything but accurate. Only fifteen when Abigail Smith

\footnotetext{
${ }^{57}$ Ibid, 4, 8.

${ }^{58}$ Phyllis Lee Levin, Abigail Adams: A Biography (New York: St. Martin’s Press, 1987), 4-5.

${ }^{59}$ As quoted in Akers, 10.
} 
first met the twenty-four year old John Adams, perhaps the awkwardness of immature habits made her seem too young for a Harvard graduate and rather insecure man seeking his place in the world. Adolescence grew into a more solid maturity, and by 1762, John Adams appeared smitten with the eighteen-year-old Abigail Smith. ${ }^{60}$

In letters to her, he called her "Diana, after the Roman goddess of the moon," while he signed himself, "Lysander, the Spartan hero." ${ }^{61}$ Their courtship correspondence conveys the respect and passion that would survive war, separation, children, illnesses, family strife, and the inevitable aging process. Before their marriage, even when love was new and exciting, John's attraction for Abigail extended far beyond the physical. In one diary entry, he wrote of Abigail, "Di was a constant feast. Tender feeling, sensible, friendly. A friend. Not an imprudent, not an indelicate, not a disagreeable Word or Action. Prudent, modest, delicate, soft, sensible, obliging, active.,62

A sense of fate underlines the love story of Abigail and John. Who she became was presaged long before they married. Years before he grew serious about Abigail Smith, a young, single John Adams described his thoughts on the ultimate duties of women in his journal. By raising "[a] Hero or a Legislator, a great Statesman or Divine or some other great Character that may do [Honor] to the World... [would be] the Highest

\footnotetext{
${ }^{60}$ Lynne Withey, Dearest Friend: A Life of Abigail Adams (New York: Simon \& Schuster, 1981), 13-14.

${ }^{61}$ David McCulloch, John Adams (New York: Simon \& Schuster, 2001), 55.

${ }^{62}$ John Adams in L. H. Butterfield, ed, Diary and Autobiography of John Adams (DAJA), 4 vols (Cambridge, MA: The Belknap Press of Harvard University Press, 1961), I: 234.
} 
[Pinnacle] of Glory to which a Woman can in Modesty aspire." ${ }^{, 63}$ Abigail met his expectations.

In the spring before their October 1764 wedding, John went to Boston for smallpox inoculation. Their letters during this precarious experience continued to affirm their mutual affection and commitment. In one unique exchange, which also carried with it themes that would recur throughout their marriage, Abigail asked John to identify her flaws, or 'spots,' so that she could better fashion herself into a good wife and mother. ${ }^{64}$ John responded in a rather jocular tone-perhaps a bit punchy from being confined under close quarters and most probably more so from being separated from her.

"You could never be [prevailed] on to learn to sing.... [You] often hang your Head like a Bulrush. You do not sit, erected, as you ought, by which Means...you appear to short for a Beauty, and company [loses] the sweet smiles of that Countenance and the bright sparkles of those Eyes.-This Fault is the Effect and Consequence of another still more inexcusable in a Lady. I mean [a] Habit of Reading, Writing, and Thinking.... [Sitting cross-legged] ruins the figure and...springs I fear from...too much Thinking. These Things ought not to be!... Walking...Parrot-toed...[conveys] the reverse of a bold and noble Air.... Near three weeks I have....studied for more [faults], but more are not discovered. All the rest is bright and luminous." 65

Abigail responded to John's report with relief, as she exposed herself rather vulnerably to blanket criticism. Yet, she exposed herself to the blanket criticism of a man who unabashedly loved her completely—virtues and vices. Abigail apparently knew

\footnotetext{
${ }^{63}$ Ibid, I: 195. This quote is excerpted from a January 1761 letter that John Adams wrote to his nieces. In this letter, Adams also wrote, "I would not have you Pedants in Greek and Latin nor the Depths of Science, nor yet over fond to talk upon [anything]. When your opinion is asked, give it.” Ibid, 193.

${ }^{64}$ Abigail Smith to John Adams, April 12, 1764, AFC, I: 26. Abigail Smith's reference to her 'spots' is excerpted from a passage in which she expresses that she would prefer that her "many Spots...were erased," and that she "[hopes] those faults which you discover, proceed more, from a wrong Head, than a bad Heart," as she wants to learn from John to "form a more faultless conduct."

${ }^{65}$ John Adams to Abigail Smith, May 7, 1764, AFC, I: 45-46.
} 
John's propensity for teasing her, and she did not mistake any of his observations for actual criticisms. Her mood lightened and flattered, she responded,

"I...[read] over most of my Faults with as much pleasure, as [another] person would have read their perfections. And Lysander must excuse me if I still persist in some of them, at least till I am convinced that an alteration would contribute to his happiness. ${ }^{, 66}$

Adopting his teasing tone, Abigail then informed John that "a gentleman has no business to concern himself about the [legs] of a lady.” Though, at the same time, she conceded that her singing voice was "harsh as the screech of a peacock." 67

Employing a more introspective and serious tone, John wrote to Abigail less than a month before their wedding detailing what benefits he expected to reap by her presence in his life. Similar to the accuracy of his thoughts on the ultimate goal for women, outlined before his relationship with Abigail ever blossomed, this letter expressed portentous sentiments that proved uncannily accurate during their long marriage.

"[You] who have always softened and warmed my Heart, shall restore my Benevolence as well as my Health and Tranquility of mind. You shall polish and refine my sentiments of Life and Manners, banish all the unsocial and [ill-natured] Particles in my Composition, and form me to that happy Temper, that can reconcile a quick Discernment with a perfect [Candor].,"68

John expected much more than just a stereotypically submissive and silent housewife. He looked to Abigail as a refuge and a model of the values and temperament he hoped to emulate in his public life. Moreover, as she would "polish and refine” him, John would

\footnotetext{
${ }^{66}$ Abigail Smith to John Adams, May 9, 1764, Margaret A. Hogan and C. James Taylor, eds, My Dearest Friend: Letters of Abigail and John (Cambridge: The Belknap Press of Harvard University Press, 2007), 21.

${ }^{67}$ Ibid.

${ }^{68}$ John Adams to Abigail Smith, September 30, 1764, AFC, I: 49.
} 
support her intellect, which he implicitly and explicitly admired and approved of-hence the teasing remarks about her 'spots,' and the fact that in imitating Richard Cranch, he too had taken an interest in her reading by "bringing books for her" during their courtship. $^{69}$

On October 25, 1764, Abigail and John exchanged marriage vows in her father's Weymouth, Massachusetts church, and Reverend Smith presided over their ceremony. By solidifying their commitment to each other under God and in the presence of family and friends, Abigail and John's marriage came to represent the model of a marriage fashionable in England and the colonies in the mid to late eighteenth century. While their marriage even pushed the bounds of this new ideal, the bulwarks of their partnershipadmiration, respect, loyalty, and affection—-typified the qualities attributed to a “companionate” marriage. Diminished "parental control over children” in the decision over potential marriage partners fostered this “new understanding of marriage.” As a result, the traditional view of marriage as "primarily [an] economic partnership" subsided, as couples assigned more value to “emotion and companionship.”70

Abigail and John courted for several years before their marriage, and both came from upper-class families. John, a Harvard graduate, worked in one of the few elite professions of his time, and he owned his own home and land. ${ }^{71}$ Moreover, John and Abigail were both adults (Abigail was almost twenty and John was almost twenty-nine)

\footnotetext{
${ }^{69}$ Withey, 14.

${ }^{70}$ Sara M. Evans, Born for Liberty: A History of Women in America (New York: The Free Press, 1989), 6263.

${ }^{71}$ John's father, Deacon John Adams, died in 1761, and left John a house located on his property along with "forty acres... and slightly less than a third of his father's personal estate." See McCulloch, 52-53.
} 
and took a substantial window of time to get to know one another before their wedding. Abigail and John's relationship carried more meaningful grounds than the legal contract of marriage because their bond was "also a friendship.” They "required intellectual parity in a mate, and they came to depend upon each other for dialogue."72 Certainly, their early letters and courtship practices support this contention.

Writing several years following Abigail and John’s wedding, Dr. John Gregory also stressed happiness and companionship in marriage. He counseled his daughters that marriage, "if entered into from proper motives of esteem and affection, will be the happiest state for yourselves, make you most respectable in the eyes of the world, and the most useful members of society.” Yet, in a remarkable addition to this seemingly typical support of marriage as the expected goal for females, he qualified, "But I confess I am not enough of a patriot to wish you to marry for the good of the public. I wish you to marry for no other reason but to make yourselves happy."73 A biographer of Mary Wollstonecraft, the celebrated, though oft-condemned, women's rights advocate of the eighteenth-century, noted Wollstonecraft's impression of the ideal marriage. Her close friends, the Barlows—from America—exhibited a unique "bond.” Ruth Barlow was her husband Joel’s “companion; she went out with him, she knew his friends, she shared his business and political concerns, and she was informed about public affairs.” Therefore,

\footnotetext{
${ }^{72}$ Edith B. Gelles, First Thoughts: Life and Letters of Abigail Adams (New York: Twayne Publishers, 1998), 22.

${ }^{73}$ Dr. John Gregory, A Father's Legacy to His Daughters, $2^{\text {nd }}$ ed (London: W. Straham, T. Cadell, J. Balfour, W. Creech, 1774), 108-109.
} 
this relationship portrayed to the public that Ruth Barlow “was [also] a person of dignity."74

Rather in the mode of Dr. Gregory’s advice, Abigail and John entered into marriage in the hopes of "making [themselves] happy," and they shared a bond as ardent Patriots. Correspondingly, throughout their long marriage, Abigail assumed a position to John very similar to the one that Mary Wollstonecraft observed in the marriage of the Barlows. Judith Sargent Murray seemed to have Abigail and John in mind when she published The Gleaner some three decades following their marriage. Murray cautioned that "eagle-eyed discretion ought to set at [the] helm” when considering marriage. “Mutual esteem, mutual friendship, mutual confidence, begirt about by mutual forbearance - these are the necessary requisites in [a] matrimonial career.” Further, she advised that couples should “consult each other's [humors], dispositions, sentiments, and pursuits” and ascertain that they "possess... at least a similarity of views," as she identified this condition as "absolutely indispensable, if you mean to secure the social enjoyment of your lives.”75

If Murray’s counsel could be taken as a preceptor of sorts for engaged couples entering into marriage, then John and Abigail Adams would serve as the ultimate textbook case. They successfully overcame a multitude of tribulations, all the while relying on a “mutual forbearance.” Their commitment to each other sustained their stability and enhanced the upbringing of their children. Yet, Abigail shouldered this

\footnotetext{
${ }^{74}$ Eleanor Flexner, Mary Wollstonecraft: A Biography (Baltimore: Penguin Books, Inc., 1973), 140-142.

${ }^{75}$ Judith Sargent Murray, The Gleaner: A Miscellaneous Production, in Three Volumes, by Constantia (Boston: I. Thomas \& E. T. Andrews, 1798), 133.
} 
particular responsibility almost single-handedly for nearly a decade. The many successes and achievements of her children, nieces, nephews, grandchildren, and even distant generations may be attributed to her care, foresight, dedication, and steadfast principles.

\section{'To Take a Part...in the Struggle'}

For the first ten years of their marriage, Abigail and John Adams lived a rather modest existence. Abigail gave birth about once every two years, and four of her five pregnancies brought forth children who would survive into adulthood. During these years, John's legal career grew, and he spent much of his time riding the court circuit, though he was never away from home for more than a few weeks at a time. In 1768, John moved the family to Boston to shorten his travels. The year 1768 also witnessed the arrival of the British troops in Boston amidst a period of heightening tension with Great Britain over taxes and legislative authority. During next six years, John became embroiled in the controversy, as his political views crystallized into avid support for liberty from the Crown. ${ }^{76}$

The year 1770 marked a significant turning point in their marriage. Their oneyear-old daughter, Susanna Adams, died early in the year, followed by the birth of their second son, Charles Adams, in the late spring. In March 1770, the Boston Massacre occurred, and John acted as defense counsel for the British troops and captain charged in the affair. Ever since the Stamp Act of 1765, John contributed political writings to local newspaper outlets, and his reputation as a thorough, well-established political scholar grew. Instead of bringing a quick end to his rising star, as many predicted, defending the

\footnotetext{
${ }^{76}$ Withey, 32-35.
} 
British in the Boston Massacre trial identified him as one of the foremost leaders of the Patriot cause. Specifically, John agreed to this seemingly-distasteful and possiblyruinous task out of his conviction for the necessity of justice. He wrote of this conviction in his Autobiography, as he explained, "[Counsel] ought to be the very last thing that an accused Person should want in a free Country... [and] the Bar ought...to be independent and impartial at all Times [and] in every Circumstance.,"77

As he prepared his briefs for the trial, John was elected "as a representative of the Massachusetts legislature," which served as "his first real commitment to politics," and "would mean more time away from his practice, and ... reduction in income."78 In expressing his anxieties about the expectations and requirements of this new legislative position as well as the ramifications of taking on a political role instead of further pursuing his legal career, John sensed that life as he and Abigail and the children knew it was about to change drastically and irreversibly. He recounted,

"That Excellent Lady, who has always encouraged me, burst into a flood of Tears, but said she was very sensible of all the Danger to her and to our children, as well as to me, but she thought I had done as I ought, [and] she was very willing to share in all that was to come and place her trust in Providence., ${ }^{, 79}$

Over the next three and one-half years, the family moved back to Braintree and then back to Boston again. While living in Braintree, Abigail gave birth to her third son, Thomas Boylston Adams. By late 1773, matters with Great Britain tottered on a tenuous tightrope, and Abigail Adams pondered the possibility of war with her new

\footnotetext{
${ }^{77}$ Excerpted from the Autobiography section of 1770 in DAJA, III: 293.

${ }^{78}$ McCulloch, 68-69.

${ }^{79}$ Excerpted from the Autobiography section of 1770 in DAJA,, III: 294-295.
} 
correspondent, Mercy Otis Warren. Warren, wife of one of John’s colleagues, James Warren, stood as one of the rare examples of an erudite woman in eighteenth-century America who received acclaim for her historical and political writings. John introduced Abigail to Mercy, and the two women initiated a correspondence that extended through their lives.

Shortly before the Boston Tea Party in December 1773, Abigail wrote to Mercy,

"[A] civil War is of all Wars, the most [dreadful]. [Such] is the present Spirit that prevails, that if once they are made desperate, Many, very many of our Heroes will spend their lives in the cause, [with] the [Speech] of Cato in their Mouths, 'What a [pity] it is, that we can [die] but once to save our Country., ,"80

Though the actual outbreak of war laid more than a year in the distance, Abigail already displayed a sharp aptitude for taking the political pulse of the day. She widened her correspondent circle even more impressively in 1774 following Parliament's imposition of the Coercive Acts.

John encouraged noted English historian and American supporter, Catherine Macaulay, to write to Mercy Otis Warren due to Macaulay’s “[interest] in American women” and affinity for “Warren’s political ideas.” When Abigail learned of Macaulay’s interest and support of the American cause, she wrote directly to Macaulay. ${ }^{81}$ In 1774 , Abigail related the effects of the Coercive Acts in the colonies to Macaulay.

"[We] are invaded with fleets and Armies, our commerce not only obstructed, but totally ruined, the courts of Justice shut, many driven out from the Metropolis, thousands reduced to want, or dependant upon the charity of their [neighbors] for a daily supply of food, all the [Horrors] of a civil war [threatening] us on one hand, and the chains of Slavery ready forged for us on the other....[Yet, the greater part [of our population] support [our cause] with that firmness, that fortitude, that undaunted resolution which

\footnotetext{
${ }^{80}$ Abigail Adams to Mercy Otis Warren, December 5, 1773, AFC, I: 88.

${ }^{81}$ Withey, 49.
} 
ever attends those who are conscious that they are the injured not the injurer, and that they are engaged in a righteous cause."82

In the summer of 1774, John learned of his election to the First Continental Congress, and thus, the Adams' family life course dramatically changed. John was now committed to public service. He wrote to Abigail and expressed his apprehensions and need for her support in this dramatic new venture in their lives.

"I must [entreat] you, my dear Partner in all the Joys and Sorrows, Prosperity and Adversity of my Life, to take a Part with me in the Struggle. I pray God for your Health-[entreat] you to rouse your whole attention to the Family, the stock, the Farm, the Dairy. Let every Article of Expense which can possibly be spared be [retrenched]. Keep the Hands attentive to their Business, and [let] the most prudent Measures of every kind be adopted and pursued with Alacrity and Spirit.” 83

Abigail most likely sensed that John would be called to provide further service to the country if a break with the Mother Country occurred. Such further service would require greater sacrifices of his time from his personal business, and, more importantly, his family. When John embarked for Philadelphia in August 1774, Abigail had no way of knowing, however, how long he would serve his country. In turn, she had no idea how many responsibilities she would assume during his absences, and how this would have an impact on her family’s future.

\section{Resolute Revolutionary to Revered Republican Mother}

John Adams’ election to the First Continental Congress in 1774 led to four consecutive terms and summoned him away from home for nine-to-ten months at a time, especially during the debates over Independence and the initial prosecution of the war. ${ }^{84}$

\footnotetext{
${ }^{82}$ Abigail Adams to Catherine Macaulay, 1774, AFC, I: 177-178.

${ }^{83}$ John Adams to Abigail Adams, July 1, 1774, Ibid, 119.

${ }^{84}$ Withey, 85-86.
} 
During his Congressional service, John wrote frequently to Abigail. In addition to advising her on matters of the farm, household, and the children's education, he kept her apprised of the events in Philadelphia and in the nation at large.

John's encouragement and counsel of the children's education is significant. He relegated complete confidence in her abilities to oversee their progress and to challenge them to expand their knowledge. Specifically, “[John’s] affectionate respect for her intelligence and adequacy to the task, considering his elaborate curriculum and nagging regard for learning, and Abigail’s totally homemade education, was exceedingly complimentary.” ${ }^{, 85}$ His "elaborate curriculum” included profound instructions for Abigail.

"[Cultivate] their Minds, inspire their little Hearts, raise their Wishes. Fix their Attention upon great and glorious Objects, root out every little Thing, weed out every Meanness, make them great and manly. Teach them to scorn Injustice, Ingratitude, Cowardice, and [Falsehood]. Let them revere nothing but Religion, Morality, and Liberty." 86

The decisive year of 1775 brought the opening shots of the American Revolution, as well as the death of close family friend, Dr. Joseph Warren. Warren died at the Battle of Bunker Hill in June, his death strengthening Abigail’s commitment to America's struggle. In an effort to understand current affairs, she had John Quincy read Charles Rollin's Ancient History to her. This practice provided an opportunity to discuss with John Quincy "the methods by which empires were founded, by what steps they rose to... glory, and the cause for their decline and fall.." ${ }^{87}$ Upon learning this, John wrote to Abigail, “Tell [John Quincy] I am glad to hear he is so good a boy as to read to his

\footnotetext{
${ }^{85}$ Levin, 41.

${ }^{86}$ John Adams to Abigail Adams, April 15, 1776, AFC, I: 384.

${ }^{87}$ Levin, 39.
} 
Mamma, for her Entertainment, and to keep himself out of the Company of rude Children." 88

Besides stressing historical analysis, Abigail impressed on John Quincy the magnitude of the events surrounding them. For example, she took him with her to observe the Battle of Bunker Hill from the vantage point of Penn's Hill, near their home. Soon after this experience, eight-year-old John Quincy found himself “marching up and down in [the] midst” of a company of American soldiers. This company stayed at the Adams’ farm one evening while on their journey to the American army camp at Cambridge in the summer of $1775 .^{89}$ With John firmly entrenched in Congress and war now a reality in her backyard, Abigail remained in their home with ten-year-old Abigail “Nabby,” eight-year-old John Quincy, five-year-old Charles, and three-year-old Thomas.

From her vantage point, enveloped with constant rumors, the presence of troops, and proximity to the scenes of action, Abigail succinctly portrayed the chaotic and dense atmosphere of her home environment. She wrote to John that she and the children, as well as most of the neighbors, lived in such a "Scene of Confusion" that he could "hardly imagine how we live."90 Unfortunately for Abigail, war and John’s absence would not be the only trials she faced that year. In the fall, dysentery claimed the lives of not only John's younger brother — at the Cambridge army camp—-but also that of her mother and young female servant. Further, the disease threatened to claim Abigail and John’s

\footnotetext{
${ }^{88}$ John Adams to Abigail Adams, August 28, 1774, AFC, I: 145.

${ }^{89}$ Withey, 65.

${ }^{90}$ Abigail Adams to John Adams, May 24, 1775, AFC, I: 205.
} 
youngest son, Thomas, who thankfully recovered amidst Abigail's grief for her mother and servant. ${ }^{91}$

Perhaps the frequent absences of her husband, the tense climate of her surroundings, and the deaths and sicknesses of family and friends, contributed to Abigail's increasingly uncompromising position on the war and toward the British. She, in effect, became a staunch revolutionary. To Abigail, independence was a matter of principle. She often wrote to John of her impatience with Congress in making the official break with Great Britain. One such letter predated the Declaration of Independence by almost eight months and more than matched Jefferson's intensity of sentiments against the Crown.

"I could not join [today] in the petitions of our worthy parson, for a reconciliation between our, no longer parent State, but tyrant State, and these colonies. - Let us separate. [They] are unworthy to be our [Brethren.] Let us renounce them and instead of [supplications] as [formerly] for their prosperity and happiness, [let] us [beseech] the almighty to blast their counsels and bring to Nought all their devices." ${ }^{.92}$

In the summer of 1776 as Congress prepared to (finally—in Abigail's mind) declare independence from Great Britain, Abigail decided to take the children with her to Boston to undergo the inoculation process that John had endured some twelve years earlier. Nabby and Charles experienced a bad reaction to the procedure, but everyone in the Adams’ party bravely survived the ordeal. ${ }^{93}$ When John returned home in late fall 1776, Abigail knew it was temporary, and John was back in Congress again in early 1777. This time, however, he left behind a pregnant Abigail. As she had done before,

\footnotetext{
${ }^{91}$ Withey, 70-71.

${ }^{92}$ Abigail Adams to John Adams, November 12, 1775, AFC, I: 324.

${ }^{93}$ Withey, 83-84.
} 
Abigail realized that her country needed John more than she did. She related this belief to Mercy Otis Warren upon his departure.

"I had it in my Heart to [dissuade] him from going and I know I could have [prevailed], but our [public] affairs at that time [were] so gloomy an aspect that I thought if ever his assistance was wanted, it must be at such a time. I therefore [resigned] [myself] to suffer much anxiety and many Melancholy hours for this year to come."”4

Abigail's words to Mercy Otis Warren proved tragically prophetic. Just as she had endured separation for the previous three years, Abigail bravely faced another more painful trial in John's absence. In July 1777, she delivered a stillborn baby girl. Abigail displayed characteristic fortitude in her letter to John informing him of the death of his baby daughter.

"My heart was much set upon a daughter. I had a strong [persuasion] that my desire would be granted me. It was - but to [show] me the uncertainty of all sublunary enjoyments cut [off] [before] I could call it mine.,95

Some contemporary and modern commentators and historians have speculated about how and/or why John and Abigail consented to such long and frequent absences from each other. Still relatively young after ten years of marriage, (John was thirty-nine and Abigail was thirty when he first left for Congress), their four children required guidance, education, discipline, and direction for at least another decade (the youngest, Thomas, was only five in 1777). Nevertheless, Abigail and John believed in their sacrifices as essential to the future stability of the nation.

Abigail may have “basked in John’s glory to a considerable extent and enjoyed the attention she received as the wife of a public figure." She could have "persuaded him

\footnotetext{
${ }^{94}$ Abigail Adams to Mercy Otis Warren, January 1777, AFC, II: 150.

${ }^{95}$ Abigail Adams to John Adams, July 16, 1777, Ibid, 282.
} 
not to go to Congress" or abroad. Yet, had she done so, Abigail knew "how unhappy he would be,” as he would then be faced with "a life of thwarted ambition.” Clearly, “[either] way she lost," and by sacrificing for the present-in spite of the many years the present eventually consumed — “at least she had hope for the future.”96

The most probable justification for why John and Abigail sacrificed so much precious time in their marriage to public service rests with their upbringing in a Puritaninfluenced community and faith in the loyalty they pledged to each other at the commencement of their life together. Furthermore, Abigail's particular willingness to sacrifice personal comfort for the good of her community represents her embodiment of the Republican Mother. Abigail Adams displayed virtuous sacrifice in relinquishing her husband to the state and assuming all of the domestic duties, freeing John Adams to concentrate wholly on public service. In the new Republic, “[women] became the keepers of the nation's conscience, the only citizens specifically charged with maintaining the traditional republican commitment to the good of the entire community."97

John and Abigail's sacrifices of personal happiness for the good of the community placed awesome responsibilities upon Abigail. She cared for the children, provided much of their early education, and managed the home, farm, and finances. The impact of such trust in her abilities to perform these vital duties engendered a confidence in Abigail that influenced her children. Corresponding to her loving, protective, and supportive

\footnotetext{
${ }^{96}$ Withey, 117.

${ }^{97}$ Mary Beth Norton, “The Evolution of White Women’s Experience in Early America,” The American Historical Review, vol. 89, no. 3 (June 1984), 617.
} 
upbringing, John's esteem and blind faith in Abigail Adams contributed directly to her success as a mother.

Judith Sargent Murray emphasized the importance and long-term benefits arising from a sense of dignity and independence in women. In essay seventeen of The Gleaner, Murray asserted,

"If [women] were thus qualified to administer by their own efforts, to their own wants, the probability is, that impressions of this nature, would frequently prevent precipitation, and call into exercise that deliberation which ought, upon all occasions to be the concomitant of every important step." ${ }^{98}$

Early in their courtship, John displayed appreciation for Abigail's intellect.

Consequently, he affirmed his trust in her facility for "[exercising] that deliberation which... [became] the concomitant of every important step," not only for their future financial stability, but most crucially for the rearing of a daughter and three expected future public citizens of the new Republic.

Abigail Adams was always first and foremost a wife to John Adams and mother to Nabby, John Quincy, Charles, and Thomas Boylston Adams. Secondary to this role, Abigail also assumed the responsibilities of a farmer, employer, landlord, investor, merchant, manufacturer, contractor, nurse, hostess, teacher, political commentator, Patriot, and, always, an independent—-though permeable—observer and thinker. On many occasions, these many diverse roles coincided with each other, blurring her public and private roles. While performing her private domestic duties, Abigail also received complimentary acknowledgement by others for her more public capabilities. . For example, during one of John's terms in Congress, a family friend praised Abigail’s

\footnotetext{
${ }^{98}$ Murray, 168.
} 
supervision of the farm. James Warren, husband of Mercy Otis Warren, wrote to John that "Mrs. Adams’ Native Genius will Excel us all in Husbandry."99

Though she adroitly maneuvered in such public and male pursuits, Abigail remained the consummate dutiful wife and mother. Strikingly, John relished Abigail's manifold talents outside of the realm of the nursery and the hearth. In fact, he often depended upon Abigail's letters to provide information on the movements of the British troops in Boston, which he would pass on to his colleagues in Congress. Of Abigail as an informer, John once wrote,

"In Times as turbulent as these, commend me to the Ladies for Historiographers. The Gentlemen are too much engaged in Action. The Ladies are cooler Spectators.... There is a Lady at the Foot of [Penn's] Hill, who obliges me... with a clearer and fuller Intelligence, than I can get from a whole Committee of Gentlemen.”"100

Abigail and John's voluminous correspondence, which spanned fifty-odd years, vividly displays an incredible depth of sentiment. Almost as impressive as their passionate loyalty to and appreciation of each other, the intellectual depth and wide scope of the subjects they explored is remarkable in the context of their generation, in which an emphasis on and support for advanced female education was more the exception than the rule. John respected her perception, and he further praised Abigail, who never received formal education, for her writing. "If I could write as well as you, my sorrows would be as eloquent as yours, but upon my Word I cannot.”101

\footnotetext{
99 James Warren to John Adams, April 27, 1777, AFC, II: 239.

100 John Adams to Mary Palmer, July 5, 1776, Ibid, 34.

101 John Adams to Abigail Adams, October 23, 1775, Ibid, I: 312.
} 
For a man often scorned by contemporaries for “egotism,” John’s characterization of Abigail’s letters as “delicious,” and “worth a dozen of mine,” displayed his unwavering appreciation for her writing and intellect. ${ }^{102}$ Yet, John was not merely a rare exception of an erudite, progressive man who admired his wife's fine writing and keen observation skills. Abigail impressed many notable male contemporaries, including Sam Adams, Elbridge Gerry, Benjamin Franklin, Thomas Jefferson, George Washington, and American and French military officers. One of John’s colleagues, Stephen Collins, conveyed his impressions of Abigail after a visit to Massachusetts. John teasingly, but proudly, recounted Collins’ assessment of that visit to Abigail.

"He says when he [called] at my House, an English Gentleman was with him, a Man of Penetration, [though] of few Words. And this silent, penetrating Gentleman was pleased with Mrs. Adams, and thought her, the most accomplished Lady he had seen since he came out of England. -Down Vanity, for you don't know who this Englishman is." 103

In the absences of men who soldiered or served in the Congresses, many women adopted survival instincts and made sacrifices of former comforts to sustain themselves

\footnotetext{
102 John Adams to Abigail Adams, May 17, 1794, Charles Francis Adams, ed, Letters of John Adams Addressed to his Wife, 2 vols (Boston: Freeman and Bolles, 1841), II: 160. In this letter to Abigail, John wrote, "I have not, for several months...failed to receive a delicious letter, worth a dozen of mine, once a week. Some three months before this letter, John complimented Abigail's writing in a letter to her in which he informed her that her letters "give me more entertainment than all the speeches I hear. There [are] more good Thoughts, fine strokes and Mother wit in them than I hear in the whole Week." John Adams to Abigail Adams, February 4, 1794, Hogan and Taylor, eds, My Dearest Friend: Letters of Abigail and John Adams, 355. In the midst of the volatile, partisan climate surrounding the election of 1800, Alexander Hamilton wrote an inflammatory pamphlet, Letter from Alexander Hamilton Concerning the Public Conduct and Character of John Adams. Hamilton condemned John Adams' character and hoped to doom Adams' re-election to the Presidency. Though Hamilton only intended his pamphlet to be read by "a carefully picked few among the [Federalist] party elders," Aaron Burr secured a copy, and soon the pamphlet was very public. One of Hamilton's characterizations of President Adams claimed that he possessed 'disgusting egotism' and was 'liable to paroxysms of anger, which deprive him of self command and produce very outrageous behavior.' See Milton Lomask, Aaron Burr: The Years from Princeton to Vice-President, 1756-1805 (New York: Farrar, Straus, Giroux, 1979), 258.

${ }^{103}$ John Adams to Abigail Adams, September 24, 1775, DAJA, II: 182.
} 
and their families. When John Adams first went to Congress in 1774, he advised Abigail to maintain the home and farm “prudently and industriously,” and he emphasized, “Frugality must be our support.”104 Furthermore, John recognized the precarious nature of their family's situation and even adopted the popular rhetoric urging sacrifice for the public welfare. In the same letter, he admitted, "We toil, spend our Time, and tempt Dangers for the public Good-Happy indeed, if we do any good.”105 For many women, “[domestic] self-sufficiency...[became] a matter of patriotism. Every step taken to reduce dependence on foreign imports was hailed as a contribution to American successes in the war."106

Compounding economic difficulties, some women endured the division of families and ending of friendships over support for or opposition to the Revolution. Inevitably, many women suffered the deaths of family members at the hands of the enemy or the diseases caused from battle injuries or primitive camp life. Abigail Adams faced each of the preceding experiences during the American Revolution, except of course, viewing the Revolution as a distant conflict. She successfully overcame the hardships of shortages, high prices, squabbles with tenants, and precarious crop results. ${ }^{107}$ Moreover, apart from the strong Patriot figures in her own circle of family and friends, Abigail lamented over a cousin, Isaac Smith, who sided with the Loyalists and characterized the leaders of the Revolution as guilty of "capricious, unlimited

\footnotetext{
${ }^{104}$ John Adams to Abigail Adams, August 28, 1774, AFC, I: 145.

${ }^{105}$ Ibid.

${ }^{106}$ Withey, 89.

${ }^{107}$ Ibid, 67, 69, 88-89.
} 
despotism." ${ }^{108}$ Though her husband faced danger of arrest and possible death as he served in Congress and abroad, her sons were too young for battle. However, death frequently touched her domestic spectrum.

Regardless of the individual circumstances, “[for] many women, the Revolution had been a strongly politicizing experience, but the newly created republic made little room for them as political beings. "109 However active she seemed in managing her home and farm, raising her children, corresponding with John and other Patriot contemporaries, Abigail never sought public recognition for her efforts. To do so would have not only strayed from the accepted notion of women's place, but it would have conflicted with her sense of appropriate place and duty. Nevertheless, the mutual esteem that she and John assigned to each other's opinions allowed her to expound often upon prominent issues and debates of the day such as slavery, women's status, and education.

While John attended the First Continental Congress in 1774, Abigail wrote,

"I wish most sincerely there was not a Slave in the province. It [always] [appeared] a most iniquitous Scheme to me-fight [ourselves] for what we are daily robbing and plundering from those who have as good a right to freedom as we have."110

Correspondingly, pro-abolition advocates echoed Abigail’s precise argument, as they found somber irony in Jefferson's Declaration of Independence as well as the popular rhetoric decrying Britain’s bondage of the colonies as contrary to human liberty, progress, and justice. Though she and John both grew up in the presence of household

\footnotetext{
${ }^{108}$ Isaac Smith, Jr., to Mary Cranch, October 20, 1774, AFC, I: 176.

${ }^{109}$ Linda K. Kerber, Women of the Republic: Intellect \& Ideology in Revolutionary America. (Chapel Hill: The University of North Carolina Press, 1980), 11.

${ }^{110}$ Abigail Adams to John Adams, September 22, 1774, AFC, I: 162.
} 
slaves, neither of them agreed with the institution of slavery, and they never kept a human slave in their service during their marriage. ${ }^{111}$

Similar to her belief in the inequity of slavery in a country espousing freedom and liberty, Abigail Adams decried the subjection of women in America. Perhaps her most famous statement to John regarding the status of women was her March 1776 letter in which she urged that Congress should 'Remember the Ladies.' Abigail wrote,

"I desire you would Remember the Ladies, and be more generous and [favorable] to them than your ancestors. Do not put such unlimited power into the hands of the Husbands. Remember all Men would be tyrants if they could. If [particular] care and attention is not paid to the [Ladies] we are determined to foment a [Rebellion] and will not hold ourselves bound by any Laws in which we have no voice, or Representation.”112

Rather than a call for feminist agitation amidst the Revolution from Britain, Abigail Adams highlighted the lack of attention to or revision of the customary 'femme covert' role. 'Femme covert' meant that "marriage made one person of two, and that person was the husband.” Furthermore, English legal scholar William Blackstone characterized the 'femme covert' as a woman, who, when married, "had no legal rights over her children. She could not sue in court or be sued, meaning, she had difficulty taking legal action against her husband no matter how badly he treated her.”"113

\footnotetext{
${ }^{111}$ Though Adams developed a close friendship with Thomas Jefferson, a prominent slave-holder, and many of Adams' neighbors and New England colleagues owned slaves, he never wavered from his belief that "slavery [was] a 'foul contagion in the human character."' Further, despite the fact that he "had appeared in several slave cases for the owner,... he had no use for slavery. He never owned a slave as a matter of principle.” McCulloch, 132-134.

${ }^{112}$ Abigail Adams to John Adams, March 31, 1776, AFC, I: 370.

${ }^{113}$ Linda Grant De Pauw and Conover Hunt, 'Remember the Ladies:' Women in America, 1750-1815 (New York: The Viking Press, 1976), 11. 'Femme covert' is a French phrase meaning, literally, covered woman. In the legal sense, then, this 'covering' is accomplished by the man in marriage. By 'covering' his wife, the man subsumes the prerogatives of her property and her person under the English common law.
} 
In response to Abigail’s 'Remember the Ladies’ letter, John responded with his customary humor at her candid "threats," but he also seemed to assuage the underlying fear implied in her letter. John wrote,

"As to your extraordinary Code or Laws, I cannot but laugh. We have been told that our Struggle has loosened the bands of Government [everywhere]. That Children and Apprentices were disobedient - that schools and [Colleges] were grown turbulentthat Indians slighted their Guardians and Negroes grew insolent to their Masters. But your Letter was the first Intimation that another Tribe more numerous and [powerful] than all the rest were grown discontented....Depend upon it, We know better than to repeal our Masculine systems. [Although] they are in full Force, you know they are little more than Theory. We dare not exert our Power in its full Latitude. We are obliged to go fair, and softly, and in Practice you know We are the subjects."

Abigail related her exchange with John to Mercy Otis Warren and explained,

"I ventured to speak a word in behalf of our Sex, who are rather hardly dealt with by the Laws of England which gives such [unlimited] power to the Husband to use his wife Ill.... So I have [helped] the Sex abundantly."115

Abigail appeared light-hearted in her synopsis to Warren, as "[she] was not disturbed by the legal superiority of husbands, only by the lack of limitation on their power." ${ }^{116}$ Incidentally, Abigail Adams' foray into the status of women in the "Remember the Ladies" letter was not the main theme of this particular letter. Most of her letter relayed the effects of the British occupation of Boston. Abigail's suggestion for improvements of women's status in the new Republic appeared almost as an afterthought. Specifically, she wrote, "I long to hear that you have declared an [independency]—and

\footnotetext{
${ }^{114}$ John Adams to Abigail Adams, April 14, 1776, AFC, I: 382.

${ }^{115}$ Abigail Adams to Mercy Otis Warren, April 27, 1776, Ibid, 397.

${ }^{116}$ Linda Grant De Pauw, "The American Revolution and the Rights of Women: The Feminist Theory of Abigail Adams," Legacies of the American Revolution (1978), 210.
} 
by the way, in the new Code of Laws which I suppose it will be necessary for you to make, I desire you would Remember the Ladies....,117

Abigail Adams' concern over the hypocrisy of slavery and legal domination of husbands over wives convey her impressive insight and humanitarianism. Assuredly, she found comfort in the knowledge that she would never suffer injustice under a 'tyrant' husband. Yet, her preoccupation with a topic so far removed from her personal experience displays her innate sense of "right" and ability to commiserate with humanity. Her hopes for legal reforms and an end to the institution of slavery influenced her writings and her attention to contemporary debates. In this respect, what mattered to her could not have failed to make an impression upon the children directly under her care. Significantly, Abigail's sentiments against the institution had a significant impact on their eldest son John Quincy, who became an ardent abolitionist during the antebellum era.

During the Revolution, Abigail Adams confronted numerous mentally, physically, and spiritually trying circumstances. Certainly her children often knew of the stress Abigail faced, yet, she managed to foster not only their physical health, but she oversaw their educations from the moment of John's departure for Philadelphia in 1774. She arranged for John Quincy's first tutor-John Thaxter, one of her cousins and a law clerk in John's office-and while she encouraged the study of classical examples in relation to the times they faced, she also exposed them to more modern authorities. John promoted the children's education by passing along Thomas Paine's Common Sense as well as his tract, Thoughts on Government in $1776{ }^{118}$

\footnotetext{
${ }^{117}$ Abigail Adams to John Adams, March 31, 1776, AFC, I: 370.

${ }^{118}$ Withey, 61, 83-84 and Levin, 76-78.
} 
While Abigail attended carefully to the education of her three sons, who prepared for college, she also exposed Nabby to a rigorous and progressive education. Unlike most girls, Nabby studied Latin, which most contemporary essayists discouraged. Prominent in this regard, Dr. John Gregory wrote, “[If] you happen to have any learning, keep it a profound secret, especially from the men, who generally look with a jealous and malignant eye on a woman of great parts, and a cultivated understanding." "119 Though he commended his daughter for her intellectual pursuits, John Adams also understood the context of such study to the world in which they lived. Writing to Nabby he cautioned, "[You] must not tell many people of it, for it is scarcely reputable for young ladies to understand Latin and Greek.”120

Though Abigail most likely concurred with John’s caution toward Nabby, she also recognized the differences between the educations of male and female children. This divergence seemed incongruent in consideration of the increasingly prevalent emphasis in Abigail's generation of women's influence upon the public futures, contributions, and successes of [male] children. She argued,

"If we mean to have Heroes, Statesmen, and Philosophers, we should have [learned] women. The world perhaps would laugh at me, and accuse me of vanity, But you I know have a mind too enlarged and liberal to disregard the sentiment. If much depends as is allowed on the early Education of youth...great [benefit] must arise from literary accomplishments in women."121

\footnotetext{
${ }^{119}$ Gregory, 31.

${ }^{120}$ John Adams to Nabby Adams, April 18, 1776, AFC, I: 388. This caution to Nabby is reminiscent of the January 1761 letter to his nieces in which he warned them not to become "Pedants in Greek and Latin." See DAJA, I: 193.

${ }^{121}$ Abigail Adams to John Adams, August 14, 1776, AFC, II: 94.
} 
In Abigail’s generation, a "learned woman” was an anathema to most contemporary

writers. Often termed 'bluestockings,' such women reaped scorn for pursuing education

for education's sake. One “American poet put it this way: if women felt advanced

learning’s 'strict embrace,'

Farewell to [every] winning grace;

Farewell to [every] pleasing art,

That binds in chains the yielding heart;...

at her approach the roses fade,

Each charm forsakes [the astonished] maid;

And [over] her face, of sickly pale,

Thought slowly draws its loathsome veil.,”122

Abigail's views on women's education rested on her belief in the necessity of

enhanced opportunities for female intellectual improvement. In a telling example of this

conviction, Abigail once wrote to her niece Lucy Cranch of the good that would

inevitably result from providing girls with a more liberal and thorough curriculum.

"The Study of Household Good...is no doubt the peculiar province of the Female Character. Yet, surely as Rational beings, our reason might with propriety receive the highest possible cultivation. [Knowledge] will teach our sex [candor], and those who aim at the attainment of it, in order to render themselves more amiable [and] [useful] in the world, would derive a double advantage...for in proportion as the mind is informed...the face [is] [ennobled] as the Heart is elevated.... [These advantages are in no way inconsistent] with looking well to the ways of [our] household."123

\footnotetext{
${ }^{122}$ As quoted in Mary Beth Norton, Liberty's Daughters: the Revolutionary Experience of American Women, 1750-1800 (Boston: Little, Brown, and Company, 1980), 264. The term 'bluestocking' originated in the eighteenth century and referred to women who "owed their position in society to their reputation for learning.” By mid-eighteenth century, a 'bluestocking' engendered a derisive connotation, and it became synonymous with 'learned lady' or 'learned woman.' See Ada Wallas, Before the Bluestockings (London: George Allan and Unwin Ltd., 1929), foreword.

${ }^{123}$ Abigail Adams to Lucy Cranch, April 26, 1787, AFC, VIII: 25-26.
} 
Abigail emphasized education as responsible for the improvement of a woman's physical and mental health. In addition, she believed that education enhanced woman's happiness in marriage and her efficiency in domestic duties.

Several female contemporary authors expressed similar beliefs regarding marriage. Mary Wollstonecraft argued,

"When a woman's mind has gained some strength, she will in all probability pay more attention to her actions than a girl can be expected to do; and if she thinks seriously, she will [choose] for a companion a man of principle; and this perhaps young people do not sufficiently attend to, or see the necessity of doing....In a comfortable situation, a cultivated mind is necessary to render a woman contented; and in a miserable [situation], it is her only consolation. A sensible, delicate woman, who by some strange accident, or mistake, is joined to a fool or a brute, must be wretched beyond all names of wretchedness if her views are confined to the present scene.”124

Thus, the companionate marriage should also include partners who have some educational background and enough presence of mind to use discretion in any involvements with a potential spouse. Undoubtedly, Abigail Adams approved of this advice since she and John both had intelligence and developed a friendship before marrying.

Supporting Wollstonecraft’s contentions, Hannah Mather Crocker also discussed the benefits of education in enabling women to make wise choices in pursuing marriage.

"Let women, then, who lead in our first circles, condescend to cultivate their minds, and encourage useful reading; their merit will cause a swarm of thoughtless beaux to disappear from their presence, and men of more merit will form a circle about them, more worthy the name of good company.",125

\footnotetext{
${ }^{124}$ Mary Wollstonecraft, Thoughts on the Education of Daughters with Reflections on Female Conduct, in the More Important Duties of Life (London: J. Johnson, 1787), 95, 101.

${ }^{125}$ Hannah Mather Crocker, Observations on the Real Rights of Women with their Appropriate Duties (Boston: 1818), 49.
} 
Crocker contended that not only would women benefit from their education, but so would the men associated with them. Again, this advice rings true in the case of Abigail and John Adams. Both partners admired each other, drew inspiration from each other, and remained committed to their marriage, children, and country.

Though convinced that education encouraged good marriages, Abigail made no mention of education qualifying women to seek public employments or enabling them to forgo domesticity. In this respect, Abigail accepted the parameters of Republican Motherhood. The Republican Mother "was to be the [nurturing], patriotic mother who raised her children, and especially her sons, to be good Christians, active citizens, and successful competitors in the wider arena of life.”126 Placing a premium on the domestic venue of the home and the rearing of future leaders, Republican Motherhood kept women in their separate sphere while legitimizing their right to educational advancement. Moreover, “[separate] spheres allowed women to wield a power of a sort. They could feel that their efforts showed some positive result and that public motherhood contributed to the common good." ${ }^{, 27}$ Consequently, women needed education to inspire their children with "civic virtue and a concern for the public good."128

Abigail Adams' education qualified her to teach her children about republican principles. Furthermore, her marriage to a prominent Patriot and proximity to various scenes of action of the Revolution gave her a first-hand perspective to enhance her

\footnotetext{
${ }^{126}$ Norton, “Evolution,” 617.

${ }^{127}$ Paula Baker, “The Domestication of Politics: Women and American Political Society, 1780-1920,” American Historical Review, vol. 89, no. 3 (June 1984), 635.

${ }^{128}$ Ibid, 625.
} 
lessons. Republican Motherhood, however, required more than just rearing future leaders. The Republican Mother also had to sacrifice personal interest for "the family, freeing her husband and sons to express their individualism to the fullest” upon their entrance on to the public stage. ${ }^{129}$ Throughout the years of the Revolution, Abigail efficaciously executed her duties as mother, teacher, farmer, manager, and Patriot wife. In 1778, however, she faced the most difficult prospect of her marriage.

Not long after John returned from a ten month stint in Congress in November 1777, he received word that Congress had elected him to the American delegation in France. ${ }^{130}$ She endured John's recurring and lengthening absences with frequent letters and the presence of all of her children to keep her busy. Now, she faced a separation that would most likely extend beyond a year and would be compounded by the additional loss of John Quincy, who journeyed to France with his father.

When John and John Quincy left in early 1778, Abigail also prepared for the absences of the remaining children. She sent Nabby to a school in Boston for several months throughout the year, while Charles and Thomas began more formal studies. Abigail sent them to her younger sister, Elizabeth’s (Betsy’s) home, as her husband, John Shaw, was a tutor who had successfully prepared his pupils for college entrance exams. ${ }^{131}$ To compensate for absent family members, Abigail welcomed to her home her

\footnotetext{
${ }^{129}$ Norton, “Evolution,” 617.

${ }^{130}$ Levin, 100.

${ }^{131}$ Abigail Adams to John Adams, April 28, 1783, Hogan and Taylor, eds, My Dearest Friend: Letters of Abigail and John, 281. Abigail wrote of John Shaw, "I doubt not he will contribute [everything in his power towards their instruction and improvement. I last evening received letters from [Charles and Thomas], and they appear to be very contented and happy.”
} 
two-year-old niece, Louisa Smith, who came to live with her indefinitely. Louisa Smith was one of the daughters of her brother, William Smith, who constantly fell into debt. ${ }^{132}$

Early in John and John Quincy’s absence in the spring and summer of 1778, Abigail appeared to regain her spirits. One of John's colleagues in Congress, James Lovell, corresponded consistently with her and passed along information from Congress as well as anything he heard regarding John’s mission. However, Lovell was also a consummate flirt, and his pointedly amorous remarks to her caused Abigail to tell him that he was "a very dangerous man.”" 133 In the summer, the French admiral in Boston, Comte d'Estaing, invited Abigail to a dinner aboard his ship. Furthermore, Abigail enjoyed John's letters describing his impressions of France, and particularly his impressions of the uniqueness of French women. John said French women possessed a more advanced education than American women and told Abigail, "I admire the Ladies here. [Don't] be jealous.” In her response to him she explained that she was not jealous, but rather curious.

"I can hear of the Brilliant accomplishments of any of my Sex with pleasure and rejoice in that Liberality of Sentiment which acknowledges them. At the same time I regret the trifling narrow contracted Education of the Females of my own country."

As summer faded into fall, and fall faded into New England winter, Abigail grew increasingly anxious and despondent over the absence of John, John Quincy, Nabby (in school in Boston), and the endless sacrifices that she seemed destined to make. She

\footnotetext{
132 Ibid, 104.

${ }^{133}$ Withey, 104-106, and Abigail Adams to James Lovell, June 24, 1778, AFC, III: 48.

${ }^{134}$ Withey, 102; John Adams to Abigail Adams, April 25, 1778, AFC, III: 17; Abigail Adams to John Adams, June 30, 1778, AFC, III: 52.
} 
wrote several letters criticizing John for not writing enough. Even eleven-year-old John Quincy intervened on John's behalf and informed Abigail in early 1779,

"I last night had the [honor] of reading a letter from you to my [Papa]...in which you complain much of my [Papa's] not writing. He cannot write but very little because he has so many other things to think of, but he can not let slip one opportunity without writing a few lines and when you receive them you complain as bad or worse than if he had not wrote at all and it really hurts him to receive such letters." 135

The young model republican thus became counselor to the Republican Mother.

Unfortunately for John Adams, his mission to France failed, as he could never match co-minister Benjamin Franklin’s popularity, and so, when Congress appointed Franklin sole minister to France in early 1779, John and John Quincy sailed for Massachusetts. ${ }^{136}$ They arrived home in the summer of 1779, but Abigail soon faced yet another wrenching test of her willingness to sacrifice for the good of the new nation. In the fall of 1779, Congress appointed John as a "Minister Plenipotentiary to 'confer, treat, agree and conclude’ with representatives of His Most Christian Majesty, George III, in the negotiations of a peace."137 Merely several months had passed, and now once again Abigail was preparing herself for John's absence and that of John Quincy and Charles.

In accepting the loss of her eldest sons and husband, Abigail represented the model Republican Mother. Republican Motherhood identified “women’s true place in the polis” as "on its edges.”138 However, Republican Mothers did not merely remain on

\footnotetext{
135 John Quincy Adams to Abigail Adams, February 20, 1779, AFC, III: 175-176.

${ }^{136}$ Levin, 114-115.

${ }^{137}$ As quoted in Ibid, 117.

${ }^{138}$ Kerber, Women of the Republic, 12.
} 
the outskirts since they needed to "encourage in [their] sons civic interest and participation” while "[guiding] them in the paths of morality and virtue."139 Hence, Abigail always expressed an inherent interest in the events of her generation, especially as they related to John’s various responsibilities.

During John's second mission to Europe, Abigail's interest in John’s activities prompted her to step out of the outskirts “of the polis” to intercede on his behalf. When Abigail learned that Franklin and the French foreign minister, the Comte de Vergennes, worked underhandedly to seek John’s removal, Abigail ordered James Lovell to “send me by the first opportunity the whole of this dark process.” In the same letter, her apprehension and empathy for John prompted her to offer a sort of apology for her haste. She told Lovell that she also suffered in John's tribulations, and that "when he is wounded, I [bleed].”140

In spite of John’s struggles with the French, he succeeded brilliantly in his negotiations with the Dutch, which he took on almost by his own initiative. In the summer of 1780, he moved John Quincy and Charles with him to the Netherlands, where they remained for approximately one year. When Abigail learned of their move, she wrote advice to John Quincy, similar to her admonitions in the 1778 letter quoted at the beginning of this chapter. Abigail cautioned John Quincy,

"You are now become resident in a Country famous for its [industry] and frugality, and which has given Birth to many Learned and great Men.... You must not be a superficial observer, but study Men and Manners that you may be [Skillful] in both.... Youth is the proper season for observation and attention-a mind unencumbered with

\footnotetext{
139 Ibid, 283.

${ }^{140}$ Abigail Adams to James Lovell, June 30, 1781, AFC, IV: 165-166.
} 
cares may seek instruction and draw improvement from all the objects which surround it."141

Little could Abigail have imagined that soon after thirteen-year-old John Quincy received this letter, he embarked without his parents on the chance of a lifetime to apply Abigail's advice of becoming "skillful” in gauging “men and manners.”

In the summer of 1781, John Quincy left the Netherlands and accompanied Francis Dana, the first United States Minister to Russia, to St. Petersburg. Obviously, John Adams believed that his eldest son possessed the maturity, presence of mind, stability of character, and intellectual impressionability to benefit from such an important assignment. By 1782, Abigail could claim marital relation to one legal scholar-cumlegislator-cum-diplomat and parental affiliation to one diplomat-in-training. As a Republican Mother, she could not have boasted a more impressive resume.

Writing to Abigail in a rather ebullient mood in the spring of 1782, John informed her that the Dutch extended formal recognition of American independence during his tenure as the first United States diplomat to the Hague. ${ }^{142}$ Abigail responded,

"I will take praise to myself. I feel that it is my due, for having sacrificed so large a portion of my peace and happiness to promote the welfare of my country which I hope

\footnotetext{
${ }^{141}$ Abigail Adams to John Quincy Adams, January 21, 1781, Ibid, 68.

${ }^{142}$ John went to the Netherlands in the summer of 1780 amidst tensions with Franklin and Vergennes, and for nearly two years, he worked to secure Dutch recognition of the United States as well as loans. In midApril 1782, "the States General of the United Netherlands resolved 'that Mr. Adams shall be admitted and acknowledged in Quality of Envoy of the United States of North America to their High Mightinesses....On June 11 John signed five bonds in the amount of one million guilders... at 5-percent interest-allowing for a $4 \frac{1 / 2}{2}$ percent commission to the [Dutch] bankers, repayment to begin in ten years and to be completed in fifteen. Congress ratified the contract on September 14. 1782....It was the sole effective support, some would say, to languishing American credit, a crucial sum that enabled the government of the Confederation to survive until recognition of Washington's new national government under the Constitution of 1787.” Levin, 136.
} 
for many years to come will reap the [benefit], [though] it is more than probable [unmindful] of the hand that blessed them.",143

With John’s prospects in an improved and even impressive light, her eldest son experiencing first-hand the protocol and business of a foreign court, and the war over (as of the Battle of Yorktown in October 1781), Abigail seemed more at ease and focused on domestic matters, especially toward the end of 1782 and beginning of 1783 . Charles returned from Europe in the winter of 1782, which cheered her tremendously. Although he and younger brother Thomas boarded with Abigail's sister and brother-in-law for several months out of the year during their schooling, Abigail at least had three out of her four children nearby with the permanent addition of her young niece, the now six-yearold Louisa Smith. ${ }^{144}$

In late 1782, seventeen-year-old Nabby Adams grew closer to a young attorney, who, upon his first arrival in Braintree, set local gossips’ tongues wagging. Royall Tyler graduated from Harvard and seemed well on his way to establishing a reputable legal career though his youth was somewhat tinged with controversial rumors of amorous dalliances and inebriated excesses. Following in the tradition of her candor with John and willingness to expose not only herself to criticism, but others as well, Abigail subjected Tyler to John’s skeptical eye by letter. She wrote,

"[Losing] his Father young and having a very pretty patrimony left him, possessing a sprightly fancy, a warm imagination and an [agreeable] person. [He] was rather negligent in [pursuing] his business in the way of his profession; and dissipated two or [three] years of his Life and too much of his fortune for to reflect upon with pleasure....I feel too powerful a pleader within my own heart and too well recollect the

\footnotetext{
${ }^{143}$ Abigail Adams to John Adams, June 17, 1782, AFC, IV: 328.

${ }^{144}$ Withey, 143.
} 
Love I bore to the object of my early affections to forbid him to hope.... I fancy I see in him Sentiment, opinions and actions which endeared to me the best of Friends." "145

Perhaps Abigail allowed herself to become caught up in her daughter's romance with Tyler out of reminiscences for her days of courtship. By late 1782, John and Abigail had been separated for four and one-half years with only a few months interval in late 1779. Additionally, with her sons either in Europe or away at school, she enjoyed the presence of a young, intelligent, and charming man in her home. John, however, did not enjoy the portrait that Abigail had painted of Tyler. He chastened Abigail in his first response on Tyler.

“I [don’t] like your Word 'Dissipation' at all. I [don't] know what it means-it may mean [everything]. There is no Modesty and Diffidence enough in the [traits] you send me. My Child is a model as you represent her and as I know her and is not to be the Prize, I hope of any, even reformed, Rake."146

Regarding Abigail’s intimation that Nabby’s serious personality might benefit from the excitement of a romance, John took exception to this criticism of his only daughter. He praised Nabby’s composed demeanor, and he directed Abigail,

"In the Name of all that is tender [don't] [criticize] yours for the qualities which are her greatest Glory, her Reserve, and her Prudence which I am amazed to hear you call Want of Sensibility. The more Silent She is in Company, the better for me in exact Proportion, and I would have this observed as a Rule by the Mother as well as the Daughter."147

Abigail took John's criticisms seriously, and she indicated to Tyler that she could not give a complete blessing to the burgeoning relationship without John’s presence.

\footnotetext{
${ }^{145}$ Abigail Adams to John Adams, December 23, 1782, L. H. Butterfield, ed, The Book of Abigail and John: Selected Letters of the Adams Family, 1762-1784 (Boston: Northeastern University Press, 2002), 334-335.

${ }^{146}$ John Adams to Abigail Adams, January 22, 1783, Ibid, 338.

${ }^{147}$ John Adams to Abigail Adams, January 22, 1783, Ibid; Withey, 143-144
} 
Furthermore, to “get [Nabby's] mind off Tyler, Abigail sent her to Boston for an extended visit” in the winter of $1783 .{ }^{148}$ Throughout the next year, however, John collected his own intelligence about his prospective son-in-law, and he tempered and eventually abandoned his previous peremptory rejection of Tyler.

In late 1783, John received word that Congress renewed his original commission to "negotiate a treaty of commerce with Great Britain" along with Benjamin Franklin and John Jay, and he prepared for at least another year stint abroad. ${ }^{149}$ This time, however, he determined that Abigail and Nabby must join him in Europe. Abigail’s father died in the fall of that year, and by the spring of 1784, she fervently arranged for the ocean voyage and reunion with John and John Quincy. ${ }^{150}$ Learning from her mother, the moral, intellectual, and spiritual preceptress, with whom she had lived for nearly all of her nineteen years, Nabby's sense of duty and personal sacrifice overcame the pangs of her heart, and she consented to accompany her mother to Europe with the intention of marrying Tyler upon her return.

For Abigail, the endless tasks of delineating which family members, friends, and tenants would oversee which aspects of her household, farm, and financial investments overwhelmed her. Compounding these daunting issues, she had to secure definite arrangements for Charles and Thomas, who would stay permanently with her sister and brother-in-law while they prepared for college. Not only did Abigail contend with

\footnotetext{
${ }^{148}$ Levin, 146.

${ }^{149}$ Withey, 148. The original commission was revoked in the summer of 1781 when Congress expanded the peace commission. Franklin and Vergennes had informed Congress that they could not work with John, who was already in the Netherlands at the time. See Withey, 129.

${ }^{150}$ Ibid, 150-151.
} 
assuring Nabby of the usefulness of her impending separation from Tyler, arranging for her sons' education and lodging, finalizing the oversight of the family home and farm, but she painstakingly sought to convince her nervous eight-year-old niece/surrogate daughter of the temporary nature of their imminent separation. Louisa Smith "would be reassured only when Abigail promised that she could come back...when they returned from Europe." ${ }^{151}$

When Abigail and Nabby sailed for Europe in June 1784, they left behind a multitude of well-wishers and the comforts and familiarity of family, friends, and a familiar environment. They sailed to a country that they had only read about and recently sided against in the Revolution. Furthermore, they risked their lives and health to the primitive conditions of eighteenth-century oceanic travel. Nevertheless, the Adams women exemplified bravery and fortitude on the ship and concentrated more on the impending joys of reuniting with John and John Quincy. Abigail wrote to John more than a year before her voyage about how she believed her presence with him at this point in his career and after such a protracted separation was not only necessary, but required.

"I Hardly think of Enemies of terrors and storms. But I resolve with myself- to do as you wish. [If] I can add to your Happiness, is it not my duty? If I can soften your Cares, is it not my duty? If I can by a tender attention and assiduity prolong your most valuable Life, is it not my duty? And shall I from Female apprehensions of storms of winds, forego all these Calls? Sacrifice them to my personal ease? [Alas], I have not even that, for [waking] or sleeping, I am ever with you.”152

For nearly a decade, Abigail watched John leave their Braintree cottage and journey to attend the Continental Congresses or to travel to European courts. By 1784,

\footnotetext{
${ }^{151}$ Ibid, 152.

${ }^{152}$ Abigail Adams to John Adams, October 8, 1782, Butterfield, ed, The Book of Abigail and John, 328.
} 
their youngest child, twelve-year-old son Thomas, progressed under the tutelage of his uncle in preparation for college, while their eldest child, nineteen-year-old daughter Nabby, journeyed across the Atlantic with her mother while preparing for marriage. Between Nabby and Thomas, eldest son, seventeen-year-old John Quincy, traveled across the Atlantic three times, apprenticed with American diplomats in three countries, studied at world renowned universities, and trekked through thousands of miles without a parent's presence. Fourteen-year-old Charles successfully braved the Atlantic twice, once without the benefit of a parent, studied in international universities, and anticipated his entrance to Harvard.

Philosophical in the waning years of the Revolution and amidst a long period of separation, Abigail recognized the extent of how much she had sacrificed in the service of her country. While she continually yielded her personal comfort and conceded the value of such sacrifices to the future of the Republic, she also understood the distinct irony of her position. In the same letter to John in which she claimed she would "take praise to myself” for his successes in the Netherlands, Abigail divulged her poignant views on patriotism.

"Patriotism in the female Sex is the most disinterested of all virtues. Excluded from [honors] and from offices, we cannot attach ourselves to the State or Government from having held a place of Eminence. Even in the freest [countries] our property is subject to the [control] and disposal of our partners, to whom the Laws have given a [sovereign] Authority. Deprived of a voice in Legislation, obliged to submit to those Laws which are imposed upon us, is it not sufficient to make us indifferent to the [public] Welfare? Yet all History and every age exhibit Instances of [patriotic] virtue in the female Sex; which considering our situation equals the most [Heroic] of yours.”153

${ }^{153}$ Abigail Adams to John Adams, June 17, 1782, AFC, IV: 328. 
In ten years of almost single-handed authority over her children and home, Abigail Adams displayed stoicism, foresight, loyalty, empathy, and a fierce patriotism to her country. Certainly, when John left for the first Continental Congress in 1774, she hardly envisioned that a decade would pass before they would be permanently reunited. Meeting in London in the summer of 1784, Abigail and John closed a remarkable and trying period in both of their lives. As their children entered adulthood, the American Republic was born, and John's public career continued its rise. They could count on the inevitability of new challenges, opportunities, accomplishments, and adversities. Yet, their individual dynamic qualities as well as their shared core principles remained firmly in tact upon their twentieth anniversary. 


\section{Chapter Two: Theodosia Burr Alston Republican Motherhood and Education in the Next Generation}

'And why should girls be [learned] or wise, Books only serve to spoil their eyes.

The studious eye but faintly twinkles And reading paves the way for wrinkles. ${ }^{, 154}$

Eighteenth-century America offered little hope toward advancing women’s

educational opportunities, as illustrated in the contemporary poem by John Trumbull.

Though this century witnessed a philosophical Enlightenment and two pivotal political revolutions, women's place remained cemented in the private confines of the household. Despite what most contemporaries thought about highly educated females, some women possessed distinguished intellects while simultaneously serving as efficient housewives. Such a woman, admired in her own time and by succeeding generations, was Theodosia Burr Alston.

Throughout her life, Theodosia Burr Alston exemplified intelligence, loyalty, affection, strength, and perseverance. Her intellectual achievements were exceptional for her time for either sex, and her gentle, warm demeanor impressed all who interacted with her. She was highly admired not only by female contemporaries, but many important male figures of the day such as Dr. Jeremy Bentham, Dr. Benjamin Rush, Mohawk Chief Joseph Brant, painters John Vanderlyn (also her father’s protégé) and Karl Frederick von Breda, and Napoleon’s brother, Joseph Bonaparte. Contemporaries revered Theodosia for her outstanding brilliance, captivating charm and charisma, and graceful elegancy. She proved that brains and beauty were not mutually exclusive characteristics.

\footnotetext{
${ }^{154}$ John Trumbull, as quoted in Linda K. Kerber, Women of the Republic: Intellect \& Ideology in Revolutionary America (Chapel Hill: The University of North Carolina Press, 1980), 185.
} 
Theodosia Burr Alston’s intellect exceeded all constraints and measures of her time, but she exuded femininity in appearance and conduct. Clearly, her erudition only served to embellish her natural traits and gained her esteem of male and female contemporaries. It is important to indicate, however, that Theodosia Alston was not educated for the sole purpose of becoming a Republican Mother. Her father and mother were so impressed by Mary Wollstonecraft's arguments in her seminal 1792 work, Vindication of the Rights of Woman, that Aaron Burr immediately set out to refine his conceptual framework for how his young daughter (then 9 years old) was being educated. Specifically, Burr was determined to make his daughter

“his 'fair experiment,' his personal project for correcting the causes of the apparent 'rare display of genius in women.' She would possess ease and grace, showing none of the pomposity of the pedant or the insipid chatter of an untrained mind."155

\section{The Burr Tradition}

Aaron Burr's lineage and education qualified him for the role of educator, as his father, grandfather, and great-grandfather were well-known, respected intellectual divines. His great-grandfather, Timothy Edwards was a minister and educator in Connecticut. Reverend Timothy Edwards educated his ten daughters in the same manner as his one son and those pupils who prepared under his direction for entrance into Harvard and Yale. The result was that

"[his] girls were so skilled in classical languages that 'when called away from home, as he often was in his capacity of eminent divine, he left the instructions to his daughters in Latin and Greek, and particularly directed that they shall not fail to hear the recitations of the young men.,”156

\footnotetext{
${ }^{155}$ Nancy Isenberg, Fallen Founder: The Life of Aaron Burr (New York: Viking Penguin, 2007), 81.

${ }^{156}$ As quoted in Richard N. Cote, Theodosia Burr Alston: Portrait of a Prodigy (Mount Pleasant, SC: Corinthian Books, 2002), 5.
} 
Reverend Timothy Edwards' only son, Jonathan, became one of the most noted theologians and scholars not only in his time but in American history, and he would help provide the impetus for the First Great Awakening in America. One of Jonathan Edwards’ daughters, Esther, married Aaron Burr, Sr., in 1752. Aaron Burr, Sr. was also an acclaimed minister- educator in Newark, New Jersey at the time of his marriage to Esther Edwards. Upon his graduation from Yale in 1736, Aaron Burr Sr. embarked on "his preaching apprenticeship," and at only twenty-two-years-old, he "was genuinely surprised when after a year of probation, the [First Church of] Newark parishioners asked that he be ordained as their settled minister.,157

In 1746, Aaron Burr Sr. became the second President of the College of New Jersey (after 1756 Princeton University). When he married Esther Edwards in 1752, he was thirty-six, and she was twenty. Esther Edwards has been described as

“'formed to please,' exceeding 'most of her sex in the beauty of her person, and in a decent and easy gesture, [behavior] and conversation; not stiff and starch on the one hand, nor mean and indecent on the other.",158

However, "the sixteen-year spread between bride and groom was fodder for gossip" in the Newark community until the new Mrs. Burr became more acquainted with the townspeople. ${ }^{159}$

Undaunted by skeptical and watchful eyes, Esther Burr displayed a sense of pride witnessed in her colorful letters to close friend and constant correspondent Sarah Prince

\footnotetext{
${ }^{157}$ Milton Lomask, Aaron Burr: The Years from Princeton to Vice-President, 1756-1805 (New York: Farrar, Straus, Giroux, 1979), 8.

${ }^{158}$ Ibid, 13.

${ }^{159}$ Ibid.
} 
of Boston, whose father had suggested to the Senior Burr that he make Esther Edwards' acquaintance. Writing to Ms. Prince early in her marriage to Aaron Burr Sr., Esther Burr indicated her husband's support of her education and interest in current events.

'The men say ([though] not Mr. Burr, he is not of that sort) that women have not business to concern themselves about [public affairs] but trust to those that know better and be content to be destroyed because they did all for the best. Indeed, if I was convinced that our great men did act as they really thought was for the glory of God and the good of the country, it would go a great ways to make me easy. ${ }^{160}$

Aaron Burr Sr. actively encouraged Esther Burr's educational advancement— much like her grandfather and father had done. For example, she noted in a letter to Sarah Prince, 'My husband...has persuaded me to take up Latin with him....I had learned it a little in our home at Northampton [Massachusetts], where there was much teaching of the classics. ${ }^{161}$ Perhaps one of the most telling examples of the strain of pride, wit, and education that Burr displayed throughout his life, admired in females, and passed down to his daughter, is found in his mother's account of how she defended the unique abilities of women as well as their capacity for learning and understanding.

Esther Burr confronted a College of New Jersey tutor, Mr. John Ewing, who said that women should only discuss 'things that they understand.' In recounting her reaction to Sarah Prince, Esther noted that she

'retorted several things upon him before he had time to speak again. He blushed and seemed confused.... I talked him quite silent....One of the things he said was that he never in all his life knew or heard of a woman that had a little learning but it made her proud to such a degree that she was disgustful to all her acquaintances.....162

\footnotetext{
${ }^{160}$ As quoted in Suzanne Geissler, Jonathan Edwards to Aaron Burr, Junior: From the Great Awakening to Democratic Politics (New York: The Edwin Mellen Press, 1981), 90.

${ }^{161}$ As quoted in Cote, 8.

162 Ibid.
} 
Apparently, Esther made her point quite clear as Mr. Ewing 'got up and said Your

Servant \& went off.' In hindsight, Esther admitted to Ms. Prince that her 'tongue....hangs [pretty] loose. ${ }^{, 163}$

Esther Edwards Burr experienced the many sacrifices and struggles attendant on the wife of a public figure. Regularly, she played hostess and opened her home to her husband's numerous colleagues, students, business partners, and visitors. Furthermore, she often remained at their Newark home alone with their first child, Sally Burr, who was born in 1754. Aaron Burr, Sr., as a prominent minister and President of the College of New Jersey, was often away on business, and it was during one of these trips that Aaron Burr, Jr., was born on February 6, 1756.

Though their life together seemed promising, by September of 1757, this vision rapidly deteriorated. That month, Aaron Burr, Sr. returned from an exhausting trip during which his health had suffered. Upon his return, he was informed that "the royal governor of New Jersey, Jonathan Belcher, had died.” Because of Belcher’s close relationship with the College of New Jersey, "[it] was only fitting that its president prepare the funeral sermon.” Unfortunately, this task would be "the prelude to his own [funeral]."164

Aaron Burr, Sr. died in late September 1757. Over the course of the next thirteen months, his wife, Esther Edwards Burr, his father-in-law, Jonathan Edwards, and his mother-in-law, Sarah Edwards, would follow him in death. Thus, Aaron Burr, Jr., age

\footnotetext{
${ }^{163}$ As quoted in Lomask, Aaron Burr: The Years from Princeton to Vice-President, 15.

${ }^{164}$ Ibid, 18. The Reverend Burr, already exhausted, suffered more physical and mental strain due to the task of preparing for the funeral. Further, the arduous journey to and from the funeral compounded his weakened health. He fell gravely ill soon after his return from the funeral, and he never recovered.
} 
two and one-half years and his older sister, age four and one-half years, lost the nucleus of their family in rapid succession. Fortunately, due to the social standing of their parents and grandparents, close family friends immediately stepped in to care for the children.

By 1760, Jonathan and Esther Edwards' eldest son, Timothy, then a twenty-oneyear-old merchant in Elizabethtown, New Jersey, assumed the role of primary caregiver and sole parental guardian of the orphaned Burr children. Along with Aaron Burr, Jr. and Sally Burr, Timothy Edwards took custody of his younger siblings (Jonathan and Sarah Edwards' youngest children). At the time he stepped into the parental role, Timothy Edwards was engaged to be married to Rhoda Ogden. Their household continued to grow almost exponentially, as they "eventually added fifteen children of their own.”165

Following in his father's tradition, Timothy Edwards made sure to provide a solid education for both of his orphaned charges. "Sally attended a girls' school in Boston," while “Aaron learned 'bravely,' as a classmate observed, at the Presbyterian Academy in Elizabethtown., ${ }^{166}$ Sally Burr eventually married one of the tutors of the Edwards and Burr children, and Aaron Burr attended Princeton University. Aaron Burr appreciated his education from an early age, and his precocious intellect and demeanor led him to assume that he would be admitted on an advanced standing. Perhaps he overreached just a bit, however, as he applied to Princeton when he was just eleven years old. Princeton’s administration turned him down, and Burr headed back to Uncle Timothy Edwards'

\footnotetext{
${ }^{165}$ Ibid, 20-21.

${ }^{166}$ Ibid, 23.
} 
home in Elizabethtown where he vowed to impress the "black-robed dignitaries" in due time. ${ }^{167}$

After two years of a rigorous, self-imposed period of intense study of the Princeton curriculum, thirteen-year-old Aaron Burr felt satisfied that not only would he be admitted to Princeton, but he should qualify for entrance as a junior. Once again, however, the administration checked his ambition, though they did admit the young scholar on the level of a sophomore. Never one to be defeated, Burr once again took what he internalized as a personal challenge on his abilities to display his intellectual prowess to those who had yet to be impressed by his efforts. The thirteen-year-old derived a seemingly excessive and rather shocking plan for mastering his studies.

"Mortified by the blow at his self-esteem, Aaron set out to show the Princeton authorities that they had underrated his abilities. During his first year as a collegian (when he was between the ages of 13 and 14!) he studied sixteen hours a day. When he discovered that his powers of concentration waned in the early afternoon, he began omitting the midday meal or eating next to nothing at that hour."168

Motivated by a challenge. Determined to refute his critics. Hopeful for recognition. Regardless of the impetus, Aaron Burr's efforts succeeded. At the end of his first year, "he received such high grades that he concluded that little or no further study was necessary." ${ }^{169}$ For his remaining two years at Princeton, he relaxed his study habits considerably, and immersed himself in the University's philosophical societies. This involvement endowed his peers and professors with respect for his skills in logic and

\footnotetext{
${ }^{167}$ Ibid, 24.

${ }^{168}$ Ibid, 25.

${ }^{169}$ Ibid, 26.
} 
rhetoric, and when he graduated in 1772 with honors, they selected him to deliver a graduation speech. $^{170}$

Upon his graduation, Aaron Burr remained at Princeton for a period and sought direction for his future professional career. During the three years separating his graduation in 1772 and his enlistment with the Continental Army in 1775, he attempted and decided against a career in divinity, and he initiated legal studies, which would later provide his life's work. When the American Revolution began in the spring of 1775, Aaron Burr, a nineteen-year-old Princeton graduate, claimed as impressive a family reputation and tradition as any young gentleman of his time. However, he did not rest upon his family for his laurels. He soon became a distinguished officer in the Revolution, and his military bravery and exploits would be remembered throughout his life by both his friends and enemies alike.

\section{War, Love, and a 'Modern' Marriage}

During the American Revolution, Aaron Burr met the love of his life, though the circumstances surrounding his courtship of his future wife provided yet another looming obstacle for the brave and eager young officer always primed for a challenge. Refined, educated, affable, and respected, Theodosia Bartow Prevost was the wife of a British military officer, Lieutenant-Colonel James Mark Prevost. She and her husband and their children (three daughters and two sons) lived at The Hermitage, a beautiful country home in Paramus, New Jersey. ${ }^{171}$ Theodosia Prevost was the daughter of Ann Stilwell and

\footnotetext{
${ }^{170}$ Ibid, 29-30.

${ }^{171}$ The Prevost’s home was “named after Jean-Jacques Rousseau’s famous cottage.” Isenberg, 64. Theodosia Prevost's husband and his brother, General Augustine Frederic Prevost, were Swiss émigrés, who "[joined] the English army when Parliament authorized His Majesty to grant commissions to foreign
} 
Theodosius Bartow of Shrewsbury, New Jersey. Her father was a lawyer, and her mother was known as "one of the six daughters of Richard and Mercy Sands Stilwell, of Shrewsbury, all noted for their beauty.”"172 While pregnant, Ann Bartow suffered the loss of her husband. Several years later, Ann Bartow married “Captain Philip De Visme of the British army, a union that, by the time of the captain's death in 1762, gave Theodosia three half brothers and two half sisters."

During the Revolution, Theodosia Prevost, her children, her mother, and several half-sisters lived at the Hermitage. By all appearances, a Loyalist family, however, the Hermitage women possessed adept social graces, and they welcomed both American and British officers into their home. In fact, the Hermitage served as General George Washington's headquarters for a short period following the brutal 1778 Battle of Monmouth Court House. ${ }^{174}$ Unlike many of their contemporaries, the Prevost and De Visme women never lost their property, most likely due to the influence and intercession of prominent American figures who had been their guests during the Revolution. Theodosia Prevost's husband died in late 1781 while serving in Jamaica. By the time of her husband's death, Mrs. Prevost and Aaron Burr had been acquainted for

Protestants.” The Prevosts spoke fluent French at home, and Theodosia was well read in Enlightenment philosophy, which would delight her future husband, Aaron Burr. They both admired Rousseau's works and would later incorporate his educational philosophies in rearing their daughter. See Lomask, Aaron Burr: The Years from Princeton to Vice-President, 66, 68.

${ }^{172}$ Lomask, Aaron Burr: The Years from Princeton to Vice-President, 65.

${ }^{173}$ Ibid, 66.

${ }^{174}$ Isenberg, 64. 
several years, and had developed a close friendship. ${ }^{175}$ In fact, within a year of their supposed first meeting, Burr proudly conveyed a remarkably affectionate relationship with Mrs. Prevost to his sister, Sally. Relaxing at the Hermitage during a temporary break from military action, Burr wrote Sally,

"Like the wandering Dove returns your wearied Brother- - he returns to find in the arms of an Affectionate Sister that rest which the world will not afford him.... I write from the house of our lovely sister-believe me Sally she has an honest and Affectionate heart.-We talk of you very often - her highest Happiness would be to see and love you.",176

Furthermore, several months following this letter, Burr boldly sought to secure the release of Theodosia's brother from a military prison. He explained to Sally, "I am on my Way to Boston-the Brother of our Sister [Prevost] is there a Prisoner-how happy if I am his Deliverer!”"177 Burr’s exclamation hardly portrays a tense, nervous young officer on a seemingly uncomfortable and delicate mission. On the contrary, Burr's closing line suggests a man rather excited for the prospect of playing the hero for the woman whom he hopes to impress.

As evidenced in his complimentary picture of her attributes as well as his willingness to intercede on her behalf, Aaron Burr developed a quick and endearing admiration for Theodosia Prevost. Although ten years his senior and the wife of an officer of the enemy, Mrs. Prevost garnered the esteem of Burr and many of his fellow

\footnotetext{
${ }^{175}$ Richard N. Cote, Nancy Isenberg, and Milton Lomask all trace the earliest meeting of Aaron Burr and Theodosia Prevost to late 1777 while Burr was stationed close to the Hermitage. See Lomask, Aaron Burr: The Years from Princeton to Vice-President, 67, Isenberg, 64, and Cote, 31.

${ }^{176}$ Aaron Burr to Sally Burr Reeve, November 5, 1778, Mary Jo Kline, ed, The Papers of Aaron Burr, Series I: Correspondence (Glen Rock, NJ: Microfilming Corporation of America, 1977), Reel I: Frame 267.

${ }^{177}$ Aaron Burr to Sally Burr Reeve, April 25, 1779, Ibid, Frame 404.
} 
officers for her intelligence, cultivated taste, sympathetic affections, and social abilities.

As his friend, Robert Troup, wrote to Burr regarding her,

"Watkins was kind enough to deliver me yours of the $8^{\text {th }}$ of December, written, I presume at Paramus. I almost envy you the happiness you have enjoyed. From the first moment of my acquaintance with Mrs. Prevost and her sister, I conceived an admiration for them both, which is much increased by the opinion you entertain of them."

In addition to Burr's fellow officers and friends, Theodosia. Prevost impressed General George Washington. During the ordeal to secure her brother’s release from imprisonment, Theodosia sought Washington’s assistance. Though he explained that he could not guarantee her brother’s release, Washington assured Mrs. Prevost of his esteem for her.

"I should be happy could I consider myself at liberty to comply with your request in the case of your brother.... But, as I have heretofore taken no direction in the disposal of marine prisoners, I cannot with propriety, interfere on the present occasion, however great the satisfaction I should feel in obliging where you are interested. Your good sense will perceive this, and find a sufficient excuse in the delicacy of my situation."

Mrs. Prevost may have even swayed General Washington's appointment of Burr as a “military escort for three prominent Loyalists.”

In “August 1778....Theodosia and her (half) sister Catherine De Visme accompanied [the escort] party on a five-day journey from New Jersey...down the Hudson River to British-held New York City....Burr received the assignment only a month after General Washington had visited the Hermitage (in 1778), [and so], it appears likely that Theodosia's good word probably swayed the commander to choose Burr for the job." 180

\footnotetext{
${ }^{178}$ Robert Troup to Aaron Burr, January 16, 1780, Matthew L. Davis, ed, Memoirs of Aaron Burr with Miscellaneous Selections from his Correspondence (Memoirs), 2 vols (New York: Harper \& Brothers, 1836), I: 88-89.

${ }^{179}$ George Washington to Theodosia Prevost, May 19, 1779, Ibid, 186.

${ }^{180}$ Isenberg, 67.
} 
Indeed, Theodosia Prevost claimed an impressive reputation as an intellectually advanced woman, a graceful, tactful hostess, and an admired influence upon the pivotal political and military officials of the day.

After the battle of Monmouth Court House in 1778, Aaron Burr's health suffered. He never regained enough of his former vitality to feel confident in continuing his military service. In 1779, Burr’s military career ended, and he soon returned to his legal studies. All the while, Burr and Theodosia Prevost continued to develop their relationship, and their letters display the deep, emotional and intellectual connection that they shared. Burr admired Mrs. Prevost's candid thoughts on their future plans, and he solicited her opinions on major philosophical and literary works.

Occasionally, Theodosia Prevost’s opinions differed from those of Burr. For example, many gentlemen of Burr's day followed the advice of Lord Chesterfield's Letters to His Son. Chesterfield's advice on social comportment urged “intrepidity,....self-possession,...consideration for others,... [and] pursuit of knowledge,” though his views on females were in line with conventional stereotypes of women as the weaker and subordinate sex. ${ }^{181}$ To Burr, Mrs. Prevost countered,

'The indulgence you applaud in Chesterfield is the only part of his writings I think reprehensible. Such lessons from so able a pen are dangerous to a young mind, and ought never to be read till the judgment and the heart are established in virtue....You have, undoubtedly, a mind superior to the contagion. ${ }^{182}$

In a method that he follow later in life and encouraged in those closest to him, Burr detailed his days and thoughts for Theodosia Prevost in a private journal. His

\footnotetext{
${ }^{181}$ James Parton, as quoted in Lomask, Aaron Burr: The Years from Princeton to Vice-President, 68.

${ }^{182}$ Theodosia Prevost to Aaron Burr, February 12, 1781, Memoirs, I: 224-225.
} 
willingness to express his emotions to her is striking even today, but even more so

considering the context of his time. In one entry written during the time he was preparing for the New York bar exam, Burr complained that he suffered from

"[a] sick headache this whole day.... I took the true Indian cure...Made a light breakfast of tea, stretched myself on a blanket before the fire, fasted till evening, and then tea again. I thought through the whole day, that if you could sit by me, and stroke my head with your little hand, it would be well; and that, when we are formally united, far from deeming a return to this disorder..., I should esteem it a fortunate apology for a day of luxurious indulgence, which I should not otherwise allow myself or you."183

Though he stemmed from a proud, erudite, and dignified lineage, Burr never felt insecure about exposing the truths of his heart to those he loved. Significantly,

"Eighteenth-century marriages pretended to be built on friendship and affection, but few actually were. The union of Aaron Burr and the previously married Theodosia, however, would be.... Their letters brimmed with need. They were earnest and resolute, as much as they were affectionate. To his future wife, and to her alone, perhaps, his life was an open book." 184

Although Aaron Burr found his true soul mate in Theodosia Prevost, and now that she was widowed he was free to marry her, her poor health cast a shadow on their happiness from the outset of their relationship. Almost a year and a half before their wedding, Mrs. Prevost's health appeared precarious, and she acknowledged that it hindered her ability to communicate with Burr. In the same letter in which she criticized Lord Chesterfield, she instructed Burr, "I am happy that there is a post established for the winter. I shall expect to hear from you every week. My ill health will not permit me to return your punctuality. You must be contented with hearing once a fortnight." 185

\footnotetext{
${ }^{183}$ Aaron Burr to Theodosia Prevost, December 5, 1781, Ibid, 233.

${ }^{184}$ Isenberg, 72.

${ }^{185}$ Theodosia Prevost to Aaron Burr, February 12, 1781, Memoirs, I: 224.
} 
Aaron Burr's concern for his future wife’s health pervaded many of his letters.

Early on in their relationship, he cautioned her,

"It is of the first importance that you suffer as little as possible the present winter. It may, in a great measure, determine your health ever after. I confess I have still some transient distrusts that you set too little value on your own life and comfort. Remember, it is not yours alone."186

Similarly, before their marriage, Burr urged her to adopt his practice of journaling her daily activities. Yet, he tempered this request with a cautionary mind to her health. He promised to

'devote one quarter of an hour a day to you. In return, I demand one half of an hour every day from you; more, I forbid; less on special occasions. This half hour is to be mine, to be invariably at the same time, and, for that purpose, fixed at an hour least liable to interruption, and as you shall find most convenient. ${ }^{, 187}$

After their marriage, Burr's anxieties over her health prompted her to address the issue at the outset of some of her letters to enable her to move on to other subjects. For example, in a 1787 letter, she wrote, "My health is better. I fondly believe this [is] the most interesting intelligence I can give Thee. I make it my preamble.”188

Often, Burr grew impatient with Theodosia Prevost Burr’s ability to protect her health, and he constantly apprised her of how he believed she should conduct her daily activities. In the spring of 1785, Burr directed her to “[go] to bed early, and do not fatigue yourself with running about house. And upon no account any long walks, of which you are so fond, and for which you are so unfit. Simple diet will suit you best.”"189

\footnotetext{
${ }^{186}$ Aaron Burr to Theodosia Prevost, December 6, 1781, Ibid, 235.

${ }^{187}$ Aaron Burr to Theodosia Prevost, December 6, 1781, Ibid.

188 Theodosia Prevost Burr to Aaron Burr, November 1787, Ibid, 279.

189 Aaron Burr to Theodosia Prevost Burr, May 12, 1785, Ibid, 262.
} 
As her health weakened throughout the course of their marriage, Burr sought cures for her by contacting prominent physicians and providing explicit details of her troubles. Yet again, Aaron Burr unabashedly broke down conventions of his day by making no secret of his wife’s delicate physical conditions. He later urged his young daughter to keep him constantly informed of his wife's health.

Most likely, Theodosia Prevost Burr suffered from "an 'incurable disorder of the uterus,' which possibly developed into cancer."190 The lack of advanced knowledge in the medical community regarding women's health, especially any understanding of cancer, meant that she would never be able to assess her condition accurately or find effective treatments. In addition to terrible physical pain, she also suffered mentally, as her disposition did not naturally indicate a sickly or troubled being. On the contrary, her composed, agreeable, and graceful demeanor belied the deterioration of her body. It troubled her immensely to display any hint of depression. In a letter to Burr she indicated how helpless she had become regarding her health.

"You speak of my spirits as if they were at my command, or depressed only from perverseness of temper.... Believe me, you cannot wish their return more ardently than I do. I would this moment consent to become a public mendicant, could I be restored to the same tranquility of mind I enjoyed this time twelvemonth."191

Regardless of her ailing health, their age difference, the fact that she had five children (three of these children, however, died young), was a widow of a British military officer, and that Burr had yet to be admitted to the bar, the relationship between Theodosia Prevost and Aaron Burr flourished. Burr “distinctly pursued a marriage based

\footnotetext{
${ }^{190}$ Isenberg, 46.

191 Theodosia Prevost Burr to Aaron Burr, May 1781, Memoirs, I: 226-227.
} 
on a very modern idea of friendship between the sexes."192 Certainly his admiration and encouragement of her intellectual pursuits, his interest in her children's well-being, and his avid concern and research into her sensitive health matters offer substantial proof to this assertion.

Though she was a widowed mother and lived in an impressive home, Aaron Burr only recently started his legal career. Thus, Burr did not possess an immediate wealth of funds to support his new wife and attendant family. Further, Theodosia Prevost clearly emphasized that she was not in a hurry to marry. Specifically, she informed Burr, "When I am sensible I can make you and myself happy, I will readily join you to suppress [local gossips’] malice.” Further, she counseled, “I wish you to study [law] for your own sake; to ensure yourself respect and independence; to ensure us the comforts of life, when Providence deigns to fit our hearts for the enjoyment."193

In the spring of 1782, Aaron Burr was admitted to the New York bar, and in July 1782 at the Hermitage, Aaron Burr and Theodosia Prevost married in a ceremony along with her half-sister, Catherine De Visme and Dr. Joseph Browne. As proof of their humble finances as newlyweds, Mrs. Burr wrote to her new sister-in-law, Sally Burr Reeve, that the details of her wedding could be

"related in a few words. It was attended with two singular circumstances. The first is that it cost us nothing. [Browne] and [Catherine] provided abundantly and we improved the opportunity. The fates led Burr on in his old coat. It was proper my gown

\footnotetext{
${ }^{192}$ Isenberg, 72. This "very modern idea of friendship" in marriage was the "companionate marriage," which Abigail and John Adams displayed from the start of their marriage in 1764, almost twenty years before Aaron Burr married Theodosia Prevost in 1782. See Sara M. Evans, Born for Liberty: A History of Women in America (New York: The Free Press, 1989), 62-63.

193 Theodosia Prevost to Aaron Burr, May 1781, Memoirs, I: 226-227.
} 
should be of suitable gauze. Ribbons, gloves, etc., were favors from [Catherine]. The second circumstance was that the parson's fee took the only half...Burr was master of. We partook of the good things as long as they lasted and then set out for Albany where the want of money is our only grievance."194

Even though Burr soon developed a respectable name for himself as a legal mind and able counselor at court, their meager finances posed a minor and temporary frustration to the smitten couple.

Much like his mother related decades before, Burr mirrored his father's appreciation and active support for his wife's studies. On one occasion, he praised Mrs. Burr's comments on Voltaire as conveying “more good sense than all the strictures I have seen upon his works put together."195 Burr’s encouragement of an intellectual dialogue with his wife was "unusual...[because] this model of intellectual friendship was designed for two men—not husband and wife.” ${ }^{196}$ Burr even coached her on how to pursue her studies. Specifically, he advised her to read with attention to detail.

"To render anything amusing or in any degree instructive, you should never pass a word you do not understand, or the name of a person or place of which you have not some knowledge.... [Note] them down on paper, and devote an hour particularly to them when you have finished a chapter or come to a proper pause."

However unusual their relationship appeared in the context of eighteenth-century America, generations of Burr’s family members displayed a preeminent concern for

\footnotetext{
194 Theodosia Prevost Burr to Sally Burr Reeve, July 1782, The Papers of Aaron Burr, Reel I: Frame 626. (This letter, manuscript number 303, is included in the Burr Family Collection at Yale University Library, New Haven, CT).

195 Aaron Burr to Theodosia Prevost Burr, December 15, 1791, Memoirs, I: 311-312.

${ }^{196}$ Isenberg, 75.

197 Aaron Burr to Theodosia Prevost Burr, December 4, 1791, Memoirs, I: 308-309.
} 
candor between spouses, attention to intellectual enhancement, and pride in their heritage and future pursuits.

Aaron Burr's concern for his wife's health and interest in her studies resounded in his letters during the course of their marriage. In one noteworthy example of these recurring themes, Burr urged her to read a book for the purpose of summarizing its premises to him.

"Have you done running up and down the stairs?...How do you live, sleep, and amuse yourself? I wish, if you had leisure for (or, if you have not, make it), you would read the Abbe Mably's little book on the [government of the] United States. St. John has it in French, which is much better than a translation. This, you see, will save me the trouble of reading it, and I shall receive it with much more emphasis par la bouche d'amour [by the mouth of my love]." ${ }^{, 198}$

Soon into their marriage, a new theme emerged and very quickly rose to prominence in their correspondence. In June of 1783 in Albany, Theodosia Prevost Burr gave birth to Theodosia Bartow Burr. Writing to her brother-in-law, Tapping Reeve, soon after her daughter's birth, Mrs. Burr asked, 'Will you believe me, Reeve, when I tell you the dear little girl has the eyes of your Sally?’ Apparently, she wanted to name her daughter after Sally Burr Reeve, but "[Burr] would not hear of it. His heart was set on perpetuating his wife’s name." ${ }^{199}$

\section{A 'Fair Experiment'}

Not long after the birth of their daughter, Aaron Burr and Theodosia Prevost Burr moved to New York City. In this city, Burr began the political career that eventually

\footnotetext{
${ }^{198}$ Aaron Burr to Theodosia Prevost Burr, May 22, 1785, Ibid, 266-267.

${ }^{199}$ As quoted in Lomask, Aaron Burr: The Years from Princeton to Vice-President, 99.
} 
carried him to the Vice-Presidency of the United States. New York City offered enticing opportunities for new lawyers. In particular,

"it was known that the British would be evacuating New York City as soon as the definitive treaty of peace was signed," and so, "it was plain that the resumption of American control there would be attended by a plethora of legal problems, making the busy seaport on the Hudson a good place for a beginning lawyer to be.”200

Burr correctly assessed the viability of career prospects in New York City. Not only did he build a thriving law career, but soon after his family's move to the city, he won election to the state Assembly. Although New York City served as the first nation’s capital, Burr's responsibilities often kept him away from home, as the state legislature met in Albany, the state capital.

As a result, Theodosia Prevost Burr assumed the primary responsibility for overseeing the household and the education and discipline of the children. Though another daughter, Sally Burr, was born in 1785, Theodosia Bartow Burr was the only child of Aaron Burr and Theodosia Prevost Burr to survive to adulthood. After suffering the death of young Sally in 1788 as well as two miscarriages, Mrs. Burr's already precarious health continued its downward spiral. As Aaron Burr’s political and legal reputation grew, his absences from home multiplied at a time when his wife’s health declined.

Mrs. Burr's despondency over her husband's absences is palpable in many of her letters. In May 1785, she related to Burr, "When my health is ill, I find your absence insupportable; every evil haunts me.... When you write again, speak of your return. The uncertainty makes it [more] irksome.” Despite her illness and responsibilities, however,

\footnotetext{
${ }^{200}$ Ibid, 81-82.
} 
she demonstrated her loyalty and duty toward her husband. She ended this particular letter by maintaining, "But whatever present inconveniences arise, I submit to them with perfect resignation.,201

From an early age, the Burr parents urged perseverance and activity on their children. Theodosia Prevost Burr's sons by her first husband worked as clerks for their stepfather, and Burr eagerly supervised their educational progress just as he did for his biological daughter. “All family members remained under strict injunction to write to [Burr] punctually every day he was gone.”202 Aaron Burr instructed his wife that “[the] girls must give me a history of their time, from rising to night," and "[the] boys anything which interests them, and which, of course, will interest me."203 Burr further reiterated,

"To hear that [the children] are employed, that no time is absolutely wasted, is the most flattering of anything that can be told me of them. It ensures their affection, or is the best evidence of it. It ensures, in its consequences, [everything] I am ambitious of in them. Endeavor to preserve regularity of hours; it conduces exceedingly to industry."204

Mrs. Burr followed this specific request ever since their courtship, and now that business often kept him away, she continued to indulge Burr in his seemingly unquenchable desire to know how those closest to him spent their time and improved upon their knowledge and character. He jokingly indicated to her that in addition to legal briefs and proposed legislation in the state legislature, he gave the same or maybe more attention to her letters. Burr wrote, "I read your memorandum ten times a day, and

\footnotetext{
${ }^{201}$ Theodosia Prevost Burr to Aaron Burr, May 1785, Memoirs, I: 258-259.

${ }^{202}$ Cote, 53.

${ }^{203}$ Aaron Burr to Theodosia Prevost Burr, May 1785, Memoirs, I: 259.

${ }^{204}$ Aaron Burr to Theodosia Prevost Burr, May 19, 1785, Ibid, 264.
} 
[observe] it as religiously as ever monk did his devotion. Yesterday, I burnt it. To me it seemed like sacrilege.,205

Burr did not confine his attentions only to his wife's and children's scholastic endeavors. On the contrary, he trusted her opinion about current affairs and trusted her direction of business matters in his absence. Once again, Aaron Burr stepped out of prescribed boundaries of what was acceptable as “men's” and "women's” separate spheres. Not that he invited his wife into the halls of the New York Assembly or nominated her for office, but he respected her assessments so much that he passed them along to his colleagues. For example, he informed her in late 1791, "I was charmed with your reflections on the books of two of our eminent characters. You have, in a few words, given a lively portrait of the men and their works. I could not repress the vanity of showing it to a friend of one of the authors." ${ }^{206}$ In another instance, he wrote to her, "I wish you would often step into the office, and see as many as you can of the people who come on business. ${ }^{207}$

In addition to praising Mrs. Burr's analytical critiques of contemporary authors and issues and urging her to oversee the children, home, and his business, Aaron Burr shared his opinions on the status of women with her. As he expressed admiration for Mary Wollstonecraft's ideas, she equally detailed for him her respect for notable contemporary females. Prominent in this regard was her feelings about Catherine the Great. She exclaimed to Burr,

\footnotetext{
${ }^{205}$ Aaron Burr to Theodosia Prevost Burr, October 29, 1784, Ibid, 248.

${ }^{206}$ Aaron Burr to Theodosia Prevost Burr, December 13, 1791, Ibid, 310.

${ }^{207}$ Aaron Burr to Theodosia Prevost Burr, June 27, 1791, Ibid, 291.
} 
“The ladies should deify her, and consecrate a temple to her praise. It is a diverting though that the mighty Emperor of the Turks should be subdued by a woman. How enviable that she alone should be the avenger of her sex's wrongs for as many ages past. She seems to have awakened Justice, who appears to be a sleepy dame in the cause of injured innocence.”208

That she felt free to express this sentiment during a time when women who voiced political opinions were subject to scorn and criticism testifies to the level of openness and respect offered by her husband.

In his Emile, Jean-Jacques Rousseau emphasized contemporary stereotypes scorning erudite women. He warned that "a brilliant wife is a plague to her husband, her children, her friends, her [servants], everyone.”"209 A “plague to her husband” might be the perfect example of everything that Theodosia Prevost Burr was NOT to Aaron Burr. Their marriage was much more aligned with contemporary female philosopher Judith Sargent Murray, whose ideal of marriage rested on "[mutual] esteem, mutual friendship, mutual confidence, begirt about by mutual forbearance."210 The respect, admiration, candor, and accomplishment exemplified by Aaron Burr and Theodosia Prevost Burr provided a solid foundation and fertile training ground for their children to rise above societal constraints and develop uniquely individual personalities free of external obstacles.

\footnotetext{
208 Theodosia Prevost Burr to Aaron Burr, July 27, 1791, Ibid, 300.

209 Jean-Jacques Rousseau in Allan Bloom, ed. Emile, or On Education, by Jean-Jacques Rousseau (1762) (New York: Basic Books, Inc., Publishers, 1979), 409.

210 Judith Sargent Murray, The Gleaner: A Miscellaneous Production, in Three Volumes, by Constantia (Boston: I. Thomas \& E.T. Andrews, 1798), 133.
} 
Perhaps more importantly, this parental backdrop inspired the Prevost and Burr children with a profound and sincere attachment to their parents. "[Burr] cared, and they knew he cared." ${ }^{, 11}$ As proof of this sentiment, Mrs. Burr indicated in 1785,

"The family as you left it. Bartow (her youngest son by her marriage to Mr. Prevost) never quits the office, and is perfectly obliging. Your dear little daughter seeks you twenty times a day; calls you to your meals, and will not suffer your chair to be filled by any of the family.",212

While some contemporary observers and modern historians have criticized Burr's intense demands upon his children's upbringing as too severe and even harmful, the children's affection for him never wavered. In fact, Mrs. Burr once informed her husband that their young daughter’s “attachment [to him] [was] not of a common nature.”213

As Bartow and Frederick (Theodosia's only two surviving children by her first husband) matured in age, they assumed more professional responsibilities outside of the home. Mr. and Mrs. Burr provided Bartow and Frederick with support and opportunities while they lived at home, which enabled the young men to successfully enter the public sphere. Bartow pursued the law, and Frederick became a gentleman farmer. Meanwhile, Theodosia Bartow Burr began an impressive array of studies under the direct guidance of her mother, who supervised her private tutors. Though he was often away on business, Aaron Burr poured advice and persistent encouragement into his letters concerning young Theodosia's pursuits. He collaborated with his wife in guiding their daughter's progress "as [Mrs. Burr] showed she could handle the standard eighteenth-century college

\footnotetext{
${ }^{211}$ Lomask, Aaron Burr: The Years from Princeton to Vice-President, 102.

${ }^{212}$ Theodosia Prevost Burr to Aaron Burr, Memoirs, I: 256.

${ }^{213}$ Theodosia Prevost Burr to Aaron Burr, August 29, 1785, Ibid, 270.
} 
curriculum.” With attention and affection, "she applied this knowledge...to the rigorous training of [young Theodosia].,214

Accordingly, by educating her daughter, Theodosia Prevost Burr passed on the educational tradition from both sides of their families and prepared young Theodosia with a solid foundation and capabilities to instruct her future children. In her role as primary proctor of her daughter's education, Theodosia Prevost Burr demonstrated Republican Motherhood. Distinctively,

"the republican mother had an awesome responsibility for children who, in the Enlightenment view, were no longer seen as stamped with willfulness and sin but rather as possessing reason and the possibility of perfection. They should be taught rationally and carefully, preferably by example, and it was the mother's role to do so successfully."215

Successfully, even though a bit of an understatement, defined how Mrs. Burr guided her daughter's progress at home. "[Young Theodosia] could read and write by the age of three. She studied mathematics, geography, Latin, Greek, French, and excelled at a pace that was well beyond her years. ${ }^{216}$ In 1791 when Theodosia was eight, the New York state legislature elected Aaron Burr as a United States Senator. This position kept him in Philadelphia, the nation's capital as of 1790 , for months at a time throughout the year. Nevertheless, his incessant attention to his daughter's education bridged any physical distance. Soon after his arrival to Philadelphia, Burr wrote to his wife, "It is surprising that you tell me nothing of Theo. I would by no means have her writing and

\footnotetext{
${ }^{214}$ Isenberg, 79.

${ }^{215}$ Evans, 65.

${ }^{216}$ Isenberg, 80.
} 
arithmetic neglected. It is part of her education which is of the most present importance."217

Several weeks later, Mrs. Burr detailed their daughter’s impressive progress. “Theo...writes and ciphers from five in the morning to eight, and also the same hours in the evening....[She] makes amazing progress at figures....You will really be surprised at her improvement."218 Though she conveyed her pride in their daughter's achievements, Mrs. Burr also made no qualms about relating the strain of supervising such a rigorous education plan in addition to running the house, supervising his business affairs, and maintaining her health during his absences. In early July 1791, she wrote,

“My time shall not be an unwilling sacrifice to others; it shall be [Theodosia's]. She shall have it, but I will not use severity; and without it, at present, I can obtain nothing; 'tis a bad habit, which she never deserves when I have her to myself.... I have so many trifling interruptions, that my head feels as if I had been a twelvemonth at sea."

Though Theodosia Prevost Burr assumed many roles in her husband’s absences, she prioritized her responsibility for nurturing the habits of study, reflection, and social poise that Theodosia Bartow Burr successfully employed all of her life. Despite his many absences during her youth, Aaron Burr remained steadfast in his commitment to the progressive education of his daughter. A nine-year-old Theodosia troubled Burr because he could not find enough suitable material for her to study, as she so quickly devoured most of her literature. Burr wrote teasingly to her,

"I rose up suddenly from the sofa, and rubbing my head- 'What book shall I buy her?' I said to myself. 'She reads so much and so rapidly that it is not easy to find proper

\footnotetext{
${ }^{217}$ Aaron Burr to Theodosia Prevost Burr, June 27, 1791, Memoirs, I: 291.

${ }^{218}$ Theodosia Prevost Burr to Aaron Burr, July 23, 1791, Ibid, 298-300.

${ }^{219}$ Theodosia Prevost Burr to Aaron Burr, July 2, 1791, Ibid, 293-294.
} 
and amusing French books for her; and yet I am so flattered with her progress in that language, that I am resolved that she shall, at all events, be gratified. Indeed, I owe it to her....I went into one bookseller's shop after another. I found plenty of fairy tales and such nonsense, fit for the generality of children nine or ten years old. 'These,' said I, 'will never do. Her understanding begins to be above such things:' but I could see nothing that I would offer with pleasure to an intelligent, well-informed girl of nine years old....I persevered. At last I found it....It is contained in two volumes octavo, handsomely bound, and with prints and registers. It is a work of fancy, but replete with instructions and amusement. I must present it with my own hand."220

Another remarkable letter countenanced Burr’s genuine devotion to his daughter

and his respect of her developing intellect as he praised her progress in composition and further reiterated his commitment to her achievements.

"In looking over a list made yesterday... of letters of consequence to be answered immediately, I find the name of T. B. Burr. At the time I made the memorandum I did not advert to the compliment I paid you by putting your name in a list with some of the most eminent persons in the United States. So true is it that your letters are really of consequence to me. I now allude to that of the $19^{\text {th }}$ instant, covering a fable and a riddle. If the whole performance was your own, which I am inclined to hope and believe, it indicates an improvement in style, in knowledge of the French, and in your handwriting. I have therefore not only read it several times, but shown it to several persons with pride and pleasure."221

Aaron Burr implicitly believed in the female intellect, and this is evidenced in an endearing letter he wrote to his wife one year before her death.

"It was a knowledge of your mind which first inspired me with a respect for that of your sex, and with some regret, I confess, that the ideas which you have often heard me express in [favor] of female intellectual powers are founded on what I have imagined more than what I have seen, except in you. I have [endeavored] to trace the causes of this rare display of genius in women, and find them in the errors of education, of prejudice, and of habit....Boys and girls are generally educated much in same way [until] they are eight or nine years of age, and it is admitted that girls make at least equal progress with the boys; generally, indeed, they make better. Why, then, has it never been thought worth the attempt to discover, by fair experiment, the particular age at which the male superiority becomes so evident?"222

${ }^{220}$ Aaron Burr to Theodosia Bartow Burr, October 8, 1792, Ibid, 317-318.

${ }^{221}$ Aaron Burr to Theodosia Bartow Burr, February 24, 1793, Ibid, 365.

${ }^{222}$ Aaron Burr to Theodosia Prevost Burr, February 15, 1793, Ibid, 362. 
What is so striking in this letter is Burr's willingness to concede that before he met his wife, he too, shared many of society’s preconceived stereotypical assumptions about the ability or lack thereof of women to develop the same level of intellectual capacity as men. Ever the pragmatist, when presented with a problem, Burr sought a solution through researching the roots of the predicament.

\section{A 'Vindication' and a Mission}

Aaron Burr's observation of the parallel progress of young boys and girls up to a certain age makes sense when one considers the typical age at which a young boy began to prepare for collegiate studies. Burr, himself, earned admittance to Princeton at thirteen and only after two years of studying on his own. Thus, the divergence of boys and girls' education at "eight or nine years of age" closely coincided with the years that a boy, depending on his social status, prepared for collegiate admittance or become apprenticed to a trade or farm. Accordingly, a young girl, depending upon her social status, took up domestic duties and, if upper-class, she practiced fashionable talents such as music, dancing, and sewing.

Soon after Burr asked his wife about the possible merits of a 'fair experiment' in comparing female and male intellectual capacities, he found his answer in Mary Wollstonecraft's Vindication of the Rights of Woman. Burr excitedly wrote to his wife about his impressions of this work.

"You have heard me speak of a Miss [Wollstonecraft], who has written something on the French Revolution; she has also written a book entitled Vindication of the Rights of Woman. I had heard it spoken of with a coldness little calculated to excite attention; but as I read with avidity and prepossession everything written by a lady, I made haste to procure it, and spent the last night, almost the whole of it, in reading it. Be assured that 
your sex has in her an able advocate. It is, in my opinion, a work of genius. She has successfully adapted the style of Rousseau's [Emile]; and her comment on that work, especially what relates to female education, contains more good sense than all the other criticisms upon him which I have seen put together. I promise myself much pleasure in reading it to you."223

In the Vindication, Burr found the impetus for his mission to provide young Theodosia with an ungendered education, and he vowed, "I hope yet by her, to convince the world what neither sex appear to believe—-that women have souls!"224

While Aaron Burr excitedly contemplated the possibilities and implications of his daughter's education, he acknowledged his enthusiasm for Wollstonecraft as an unparalleled sentiment, as many of his contemporaries denounced her. In the same letter to his wife in which he enthusiastically expressed his newfound ambition for young Theodosia’s curriculum, Burr questioned, "Is it owing to ignorance or prejudice that I have not yet met a single person who had discovered or would allow the merit of this work?”225 Because Mary Wollstonecraft bore two illegitimate children and admitted to several lovers, many men and women in America scorned her writings. In 1801, “Alice DeLancy Izard informed her daughter Margaret Manigault that she was reading the book aloud to her husband, Ralph, or rather, she said

\footnotetext{
${ }^{223}$ Aaron Burr to Theodosia Prevost Burr, February 16, 1793, Ibid, 363.

${ }^{224}$ Aaron Burr to Theodosia Prevost Burr, February 8, 1793, Ibid, 362. This quote is excerpted from a letter in which Burr relates to his wife his encounter with a local family while he was living in Philadelphia. "I am more and more struck with the native good sense of one of that family, and more and more disgusted with the manner in which it is obscured and perverted: cursed effects of fashionable education! Of which both sexes are advocates and yours eminently the victims. If I could foresee that Theo. would become a mere fashionable woman, with all the attendant frivolity and vacuity of mind, adorned with whatever grace and allurement, I would earnestly pray God to take her forthwith hence. But I...hope yet by her, to convince the world....” Ibid, 361-362.

${ }^{225}$ Aaron Burr to Theodosia Prevost Burr, February 16, 1793, Ibid, 363.
} 
'as much of it as I could read, for I was often obliged to stop, and pass over, and frequently to sigh and stammer, etc. He is as much disgusted with the book as I am...and calls the Author a vulgar, impudent Hussy.,"226

In spite of the prevalence of criticisms of Wollstonecraft's Vindication, Aaron Burr and his wife believed that their daughter blossomed under their system. By the age of ten, “Theodosia was reading Terence and Horace in the original Latin, studying Greek, perusing Gibbon, playing harp and the piano, taking lessons in ballet, and learning to skate. ${ }^{227}$ Far from suffering from the strain of tackling so many subjects and activities before adolescence, young Theodosia enjoyed displaying her talents. This is evidenced in one of Mrs. Burr's letters to Aaron Burr in which she relates, “The moment we are alone she tries to amuse me with her improvement, which the little jade knows will always command my attention.”228

That Burr and his wife felt confident in exposing their young daughter to instruction in Latin and Greek is significant when contrasted with a contemporary perspective. The contemporary journal, Lady's Magazine, published the story of Amelia to convince the public of the uselessness of cultivating the female intellect.

"Amelia is a clergyman's only daughter; she is taught Latin and Greek, with the result that she becomes 'negligent of her dress,' and 'pride and pedantry grew up with learning in her breast.' Eventually, she is avoided by both sexes, and becomes emblematic of the fabled 'white-washed jack dawl who, aiming at a station from which nature had placed him at a distance, found himself deserted by his own species, and driven out of society...." In conclusion, the editors caution that 'because a few have

\footnotetext{
${ }^{226}$ As quoted in Mary Beth Norton, Liberty's Daughters: the Revolutionary Experience of American Women, 1750-1800 (Boston: Little, Brown, and Company, 1980), 251.

${ }^{227}$ Lomask, Aaron Burr: The Years from Princeton to Vice-President, 195.

${ }^{228}$ Theodosia Prevost Burr to Aaron Burr, July 2, 1791, Memoirs, I: 294.
} 
gained applause by studying the dead languages, all womankind should [not] assume their Dictionaries and Lexicons. ${ }^{229}$

Theodosia Bartow Burr, however, presented a sharp defiance to the "morals" in this article. Not only had she mastered Latin and Greek before adolescence, but by the age of eleven, she presided as the sole mistress of her father's household, a role which she executed with precision, poise, and efficiency.

Although eleven-year-old Theodosia Bartow Burr possessed an array of intellectual talents and a delightful disposition, she soon faced personal tragedy of a magnitude not yet experienced in her young life. Three years into Burr's Senate term, Theodosia Prevost Burr succumbed to cancer in 1794. For the last few years, young Theodosia related the various afflictions plaguing her mother to Burr. In desperation, Aaron Burr sought relentlessly for a cure for his wife, even suggesting hemlock and mercury upon the advice of the renowned Dr. Benjamin Rush. ${ }^{230}$ Along with reporting on her mother's health, Theodosia detailed her daily studies and family and community news. Her journal reflects many instances of her startling maturity and aptitude, as well as Burr's constant guidance. After reading that Mrs. Burr used bark as a medicine, Burr wrote to his daughter, "Be able, upon my arrival, to tell me the difference between an

\footnotetext{
${ }^{229}$ Lady's Magazine, Jan. 1793, as quoted in Linda Kerber, “Daughters of Columbia: Educating Women for the Republic, 1787-1815,” in Jean E. Friedman and William G. Shade, eds, Our American Sisters: Women in American Life and Thought (Lexington, MA: D.C. Heath and Co., 1982), 145.

${ }^{230}$ Aaron Burr to Theodosia Prevost Burr, December 24, 1793, The Papers of Aaron Burr, Reel III: Frame 446. (This letter, manuscript number 3111, is located in the Duke University Medical Center Library, Durham, NC). In this letter, Burr informs his wife that the hemlock "has the narcotic powers of Opium superadded to other qualities. When the dose is too great it may be discovered by a Vertigo or giddinessand that he [Dr. Rush] has known it to work wonderful Cures.”
} 
infusion and decoction; and the history, the virtues, and the botanical or medical name of the bark."231

After his wife’s death in May of 1794, Burr indicated, “My little daughter though much afflicted [and] distressed, bears the stroke with more reason [and] firmness than could have been expected from her years." ${ }^{232}$ Though she must have suffered a tremendous blow in the loss of her mother, Theodosia had been a caregiver, and she faced her mother's death with the fortitude that ran deep in the Burr family. She was not without female company for long, as her father welcomed a young French émigré and her governess into his household. Nathalie d'Lage and her governess, Madame de Senat, arrived in the United States during the last few months of Mrs. Burr’s life.

Introducing them to the city and his family, Aaron Burr provided Mme. de Senat and Nathalie access to his city townhouse, and Mme. de Senat soon opened a preparatory school for young girls in this building. Burr "held Madame de Senat in the highest possible esteem, [since] he chose her to be his daughter’s teacher." ${ }^{233}$ In Nathalie and Mme. De Senat, Theodosia received “a sophisticated French education,” sustained a close relationship with a friend "only nine months older" than she, and gained a "substitute mother who would care for her during Burr’s long absences from home.”234

Under the guidance of Mme. De Senat and several private tutors, Theodosia continued to pursue her studies with vigor. Her determination and motivation to succeed

\footnotetext{
${ }^{231}$ Aaron Burr to Theodosia Bartow Burr, January 23, 1794, Memoirs, I: 375.

${ }^{232}$ Aaron Burr to Timothy Edwards, May 24, 1794, The Papers of Aaron Burr, Reel III: Frame 547.

${ }^{233}$ Cote, 93.

${ }^{234}$ Ibid.
} 
and improve is witnessed in a particular instance when she sought her father's appreciation of one remarkable day recorded in her journal. Burr, though obviously proud of Theodosia’s record, also remained the constant teacher urging her forward.

"I obeyed faithfully the command in your letter which bade me read the journal first, and I read it with great eagerness, hoping to find what I did find in the last sentence. That $16^{\text {th }}$ [of December] was really a surprising day. Three hundred and ninety-five lines, all your exercises, and all your music. Go on, my dear girl, and you will become all that I wish. I keep carefully your letters and journals, and when we meet, you shall read them again, which I am sure you will do with pleasure. It is always delightful to see and correct our own errors."235

Not only did Burr guide her academic training, but most likely arising from his experience with his wife, he advised Theodosia on her health. In one letter, Burr warned,

"Your habit of stooping and bringing your shoulders forward onto your breast not only disfigures you, but is alarming on account of the injury to your health. The continuance in this vile habit will certainly produce a consumption: then farewell papa; farewell pleasure; farewell life....! I am astonished that you have no more pride in your appearance. You will certainly stint your growth and disfigure your person. ${ }^{\text {,236 }}$

Furthermore, Aaron Burr directed her improvement with her social skills and poise. In the same letter in which he cautioned against "stooping," Burr counseled Theodosia to take criticism respectfully. He wrote,

"Receive with calmness every reproof, whether made kindly or unkindly; whether just or unjust. Consider within yourself whether there has been no cause for it. If it has been groundless and unjust, nevertheless bear it with composure, and even with complacency."237

His daughter’s education, health, and demeanor figured prominently in Aaron Burr's letters. Regarding the latter subject, Burr reprimanded a twelve-year old

\footnotetext{
${ }^{235}$ Aaron Burr to Theodosia Bartow Burr, December 21, 1794, Memoirs, I: 384-385.

${ }^{236}$ Aaron Burr to Theodosia Bartow Burr, September 1795, Ibid, 388-389.

${ }^{237}$ Ibid, 388.
} 
Theodosia for an episode in which she displayed a seeming nonchalance to Mme. de Senat.

"I have often seen Madame...pay you the utmost attention; offer you twenty civilities, while you appeared scarcely sensible that she was speaking to you...A moment's reflection will convince you that this conduct will be naturally construed into arrogance; as if you thought all attention was due to you, and as if you felt above showing the least to anybody.... Observe how Nathalie replies to the smallest civility which is offered her."238

The prevalence of contemporary criticism and even scorn of educated women may have prompted Burr's preoccupation with emphasizing grace, social poise, and humility to Theodosia. Assuredly, in exposing his daughter to a vastly liberal and progressive education usually reserved only for young men, Burr wanted to prove the stereotypical assumption that such education would 'unsex' women categorically false.

While mistress of her father's household, Theodosia Burr entertained a variety of interesting and prominent guests. Her father's home, Richmond Hill, was a country estate outside of New York City that had once served as George Washington’s headquarters during the Revolution and housed Vice-President John Adams and Abigail Adams while the capital was located in New York City. At one time or another, American and foreign dignitaries including Thomas Jefferson, James Madison, Alexander Hamilton, members of the Livingston family, Talleyrand, Count de Volney, Louis Philippe (“Citizen King”), Jerome Bonaparte, and perhaps most notable, Mohawk Chief Joseph Brant, visited Richmond Hill. ${ }^{239}$ At fourteen, Theodosia hosted a formal

\footnotetext{
${ }^{238}$ Ibid.

${ }^{239}$ Lomask, Aaron Burr: The Years from Princeton to Vice-President, 99-101.
} 
dinner party for Brant during one of her father's absences. Relating this event in a biography of Brant,

"Col. William Leete Stone, wrote, 'Miss Theodosia received the forest chief with all the courtesy and hospitality suggested, and performed the honors of her father's house in a manner that must have been as gratifying to her absent parent as it was credible to herself.",240

As she matured into a young adult who brilliantly pursued her studies and gracefully hosted famous guests, Theodosia’s father reminded her to value her accomplishments. He wrote,

"And do you regret that you are not also a woman? That you are not numbered in that galaxy of beauty which adorns an assembly-room? Coquetting for admiration and attracting flattery? No. I answer with confidence. You feel that you are maturing for solid friendship. The friends you gain you will never lose; and no one, I think, will dare to insult your understanding by such compliments as are most graciously received by too many of your sex."241

Even as Burr saw possibilities extending beyond the parameters of the conventional domestic sphere, he did not intend his daughter to abandon her femininity. Specifically, Burr's

“ideal vision for Theodosia was that she could transcend the supposed defects of her sex....[She] was meant to exercise her reason as naturally as any man, and yet no one would doubt that she had the dignity and grace of a woman....[She] could educate her own children and serve as a model for other women. She could, in that sense, follow in her mother's footsteps and become the perfect companion, 'maturing for solid friendship.",242

In fact, most contemporary observers admired her 'dignity and grace.' In one humorous instance, New York City mayor, Edward Livingston, “escorted Theodosia

\footnotetext{
${ }^{240}$ As quoted in Ibid, 103.

${ }^{241}$ Aaron Burr to Theodosia Bartow Burr, January 23, 1797, Memoirs, I: 395.

${ }^{242}$ Isenberg, 82-83.
} 
aboard a French warship visiting the city.” Livingston "warned her, 'You must bring none of your sparks on board....We have a [gunpowder] magazine here, and we shall all be blown up."’243 Perhaps the most eloquent contemporary tribute of Theodosia Burr's charms came from an Englishman visiting the U.S. in 1798.

'Mr. Burr has introduced me to his daughter, whom he has educated with uncommon care; for she is elegant without ostentation, and learned without pedantry. At the same time she dances with more grace than any young lady of New York, Miss Theodosia Burr speaks French and Italian with facility, is perfectly conversant with the writers of the Augustan age, and not unacquainted with the language of the father of poetry [i.e., Greek]. ${ }^{244}$

\section{'Solid' Friendship}

By the time she was seventeen, Theodosia Bartow Burr possessed an education far beyond any expectation, and at the same time, contemporaries revered her for social poise, a natural, genuine exuberance, and good temper. Her father indicated his sincere admiration for the woman she had become in a touching letter.

"Many are surprised that I could repose in you so great a trust as that of yourself; but I knew that you were equal to it, and I am not deceived....[At] your age, to prefer duty to pleasure when they are in collision, is a degree of firmness rarely exhibited, and, therefore, the more calculated to inspire respect.",245

When Theodosia met her future husband, Joseph Alston, a rice planter from a prominent South Carolina family in the summer of 1800, she undoubtedly remembered her father's words of the benefit of 'maturing for solid friendship.' Her correspondence with Alston in the months preceding their marriage displays her remarkable independence of mind. She questioned the merits of marrying young, and even quoted Aristotle in her defense,

\footnotetext{
${ }^{243}$ As quoted in Ibid, 104.

${ }^{244}$ As quoted in Ibid, 82.

${ }^{245}$ Aaron Burr to Theodosia Bartow Burr, January 30, 1800, Memoirs, I: 401-402.
} 
claiming that the wise philosopher had cautioned that "a man should not marry before he is six-and-thirty."${ }^{246}$

Theodosia Burr's suitor possessed a remarkable resume. Joseph Alston attended Princeton University, studied law and was admitted to the South Carolina bar, traveled the country extensively, and belonged to a wealthy, prominent family. Though most likely impressed by the qualities of this accomplished gentleman, Theodosia Burr was not any ordinary young woman. Alston, however outstanding his external achievements, unabashedly exuded another crucial trait: he was genuinely smitten with Theodosia Burr. He would not be deterred by her independent spirit and cheeky hesitations toward marriage. On the contrary, he thoughtfully considered her reflections piecemeal and set forth a pseudo-treatise on the validity of his arguments supporting marriage at their young ages (at this time, Theodosia was seventeen and Joseph was twenty).

Boldly refuting Aristotle, Joseph Alston claimed that he would "never...adopt the opinion of anyone, however respectable his authority, unless thoroughly convinced by his arguments. ${ }^{247}$ Further, he invoked Benjamin Franklin in support of his cause.

"Dr. Franklin, a very strong advocate for my system, and, I think, at least as good authority as Aristotle, very aptly compares those who marry early to two young trees joined together by the hand of the gardener; 'Trunk knit with trunk, and branch with branch intertwined, Advancing still, more closely they are [joined]; At length, full grown, no difference we see, But [instead] of two, behold a single tree!' Those on the other hand, who do not marry till late, say 'thirty,' for example, he likens to two ancient oaks; 'Use all our force, they yield not to your hand, But firmly in their usual stances stand; While each, regardless of the other's virtues, stubborn and [fixed], its natural bent pursues!'....[It] is in youth that we are best fitted to enjoy the exquisite happiness which

\footnotetext{
${ }^{246}$ Joseph Alston to Theodosia Bartow Burr, December 28, 1800, Ibid, 424. In this remarkable letter, Joseph Alston begins by referring to a previous letter from Theodosia. He quotes her reference to Aristotle and then proceeds to write an impressive and endearing dissertation defending his case for marriage.

${ }^{247}$ Ibid.
} 
the marriage state is capable of affording....Depend upon it, the man who does not love till 'thirty' will never, never love; long before that period, he will become too much [enamored] of his own dear self to think of transferring his affections to any other object."248

Alston then defended the reputation of the South by arguing that Southern women “are well informed, all of them accomplished,” and he further expressed the benefits of living in Charleston, his home city. Referring to it as "the Montpelier of the South,” Alston qualified Charleston as "the most delightfully situated city in America, which, entirely open to the ocean, twice in every twenty-four hours is cooled by the refreshing [sea breeze].” If Theodosia remained skeptical of these assertions (and she certainly had cause to be), she could not deny her amusement and perhaps, her delight in his final argument.

"You wish me to acquire French. I already understand something of it...and, with a little practice, would soon speak it. I promise you, therefore, if you become my instructress, in less than two months after our marriage to converse with you entirely in that language. I fix the period after our marriage, for I cannot think of being corrected in the mistakes I may make by any other person than my wife. Suppose, till then, you return to your Latin, and prepare to use that tongue with me, since you are adverse to one understood by all the canaille [rabble]."249

Obviously, Joseph Alston did not share the sentiment that a refined education in typically-assigned “male” subjects would unsex women. Nor did he believe that such an upbringing would, as the contemporary writer James Fordyce commented, make women into “unamiable [creatures].”250 On the contrary, Joseph Alston fell quickly and

\footnotetext{
${ }^{248}$ Ibid, 426-427.

${ }^{249}$ Ibid, 428-433.

${ }^{250}$ James Fordyce, Sermons to Young Women (Dublin: W. Gilbert, 1796), 47. This quote is excerpted from a passage in which Fordyce discusses his displeasure with women who step too far out of their prescribed sphere by pursuing too much education and thus acquiring "freedom of ...manners." Fordyce declares, "I confess myself shocked...[at] young women of...rank, [who] [throw] off all the lovely softness of [their]
} 
definitively in love with the whole of Theodosia Burr, the accomplished, talented, spirited, willful, and graceful woman. In marrying Joseph Alston, Theodosia perpetuated the tradition of cementing a “companionate marriage,” much like her parents had done nearly twenty years before and as Abigail and John Adams had done nearly four decades before.

One month before her father was inaugurated as Vice-President of the United States, Theodosia Bartow Burr married Joseph Alston in a small ceremony in Albany, where her father completed another term in the state legislature. After proudly attending the inauguration in March of 1801 in the new capital of Washington, D.C., the newlyweds embarked on their southern journey to their South Carolina home. Despite the distance from her father, Theodosia Burr Alston kept him close to her thoughts by their long-entrenched habit of letter-writing. As she continued this habit of her youth, she also continued her studies. Furthermore, Aaron Burr continued his role as educator and suggested new reading material to her.

"In your reading, I wish you would learn to read newspapers; not to become a partisan in politics, God forbid; but they contain the occurrences of the day, and furnish the standing topics of conversation. The reading of newspapers is a knack which you will acquire in six weeks, by reading, during that time, everything. With the aid of a gazetteer and atlas, you must find every place spoken of."251

Charleston society and the Alston family welcomed Theodosia Burr Alston, though she never really became comfortable or content with the South. Renovations of Joseph Alston’s Oaks plantation were underway and would take nearly four years.

nature and [emulate] the daring intrepid temper of [men]—how terrible! The transformation...must ever be monstrous.”

${ }^{251}$ Aaron Burr to Theodosia Burr Alston, December 8, 1801, Memoirs, II: 162. 
Hence, Theodosia had no choice but to become well-acquainted with her new family since the couple lived at Hagley plantation with Joseph’s brother, John Ashe Alston, and John’s wife Sally for several years. ${ }^{252}$ Nevertheless, Theodosia reported to her sister-inlaw Frances Ann Prevost (Bartow's wife) in New York

"We arrived on the $21^{\text {st }}$ [and] the family [is] so kind [and] amiable that I am already quite at ease: the idea we have at the northward of the reserve [and] coldness of the Carolina women is ridiculous: it has at least refuted in those I have seen.,253

In addition to meeting and moving in with some of her in-laws, Theodosia Burr Alston also faced the adjustment of becoming a plantation mistress. Her "new role as mistress of a large plantation was a significant change from that of socialite mistress of Richmond Hill, for she was now responsible for the medical welfare and provisioning of over 200 slaves. ${ }^{254}$ For a cosmopolitan New Yorker accustomed to constant visitors of diverse backgrounds, polite conversation, intellectual discussions, and four specifically delineated seasons of weather, South Carolina presented a stark change of pace. Furthermore, life on southern plantations "frequently meant drudgery, isolation, and boredom." 255 Perhaps the severity of these changes explains why Theodosia Alston was so willing to leave for five or six months out of every year to return north to her father's company. However, her health also provided another impetus for her to escape the humid plantation summers.

\footnotetext{
${ }^{252}$ Cote, 130.

${ }^{253}$ Theodosia Burr Alston to Frances Ann Prevost, May 26, 1801, Dorothy Valentine Smith, “'An Intercourse of the Heart': Some Little-Known Letters of Theodosia Burr,” New York Historical Society Quarterly, vol. 37, no. 1 (January 1953), 49.

${ }^{254}$ Cote, 142.

${ }^{255}$ Ibid.
} 
Only two months after they arrived in South Carolina following their wedding, Theodosia and Joseph Alston headed north again. On this trip, they fulfilled Chief Joseph Brant's 1797 invitation to Theodosia to visit his home outside of Niagara Falls. Recounting this visit, Theodosia wrote to Frances Prevost,

"If you wish to have an idea of real sublimity, visit the Falls of Niagara-they are magnificent; words when applied to express their grandeur appear to lose half their significance- to describe them is impossible; they must be seen.,256

Aaron Burr informed his daughter that she "made two, perhaps more conquests on [her] Northern tour-King [Brant] and the stage-driver; both of whom have been profuse in their eulogies.” Burr jokingly added, “[Brant] has written me two letters on the subject. It would have been quite in style if he had scalped your husband and made you Queen of the Mohawks."257

In the spring of 1802, Theodosia and Joseph Alston awaited the birth of their first child. Burr shared in their anticipation, and he told Alston that "[the] successful ‘execution of your energies’ is highly grateful to me.” Burr jovially played on words based on President Jefferson's annual message, which had expressed that the "energies of men ought to be principally employed in the multiplication of the human race.”258 Although he was about to be a grandfather, Burr still relished his role as Theodosia's father. Almost as soon as she arrived in South Carolina, Burr sent her clothing items and

\footnotetext{
${ }^{256}$ Theodosia Burr Alston to Frances Ann Prevost, July 31, 1801, The Papers of Aaron Burr, Reel IV: Frame 1063. (This letter, manuscript number 2216, is included in the Burr Collection at the New York Historical Society, New York, NY.)

${ }^{257}$ Aaron Burr to Theodosia Burr Alston, November 3, 1801, Memoirs, II: 155.

${ }^{258}$ Aaron Burr to Joseph Alston, December 13, 1801 and February 2, 1802, Ibid, 162-163; 170.
} 
requested, "I wish you would often give me orders, that I may have the pleasure of doing something for you or your amiable family.”259

Now that she was pregnant, Aaron Burr's preoccupation with Theodosia's health inspired him to send a cook and a maid to her despite the fact that Joseph and his family had many household slaves already present in each of their plantation and city homes. In one letter Burr told her that she "must walk a great deal,” even if it meant having "ten negroes at [her] heel” (in the event that Joseph could not attend to her) ${ }^{260}$ Soon after this letter, Burr wrote to caution Theodosia against dental work: "Do not suffer a tooth to be drawn, or any operation to be performed on your teeth.”261 In addition, he took his advice on Theodosia's health to her husband. Writing to Joseph several months before her due date, Burr wanted to persuade him to take Theodosia to the South Carolina mountains for her labor.

"The situation of Theodosia, so far from being an objection, ought, in my mind, to be an additional strong motive. With her Northern constitution she will bring you some puny brat that will never last the summer out; but, in your mountains, one might expect to see it climb a precipice at three weeks old.",262

Similar to his injunctions of her childhood, Aaron Burr loved to remind her that she never wrote as often as she should. He often played upon her guilty conscious, as in the same letter as the dental work caution he exclaimed,

\footnotetext{
${ }^{259}$ Aaron Burr to Theodosia Burr Alston, April 29, 1801, Ibid, 151.

${ }^{260}$ Aaron Burr to Theodosia Burr Alston, January 16, 1802, Ibid, 168. In this letter he also specified what type of shoe she should wear on her walks. He advised her to get "a very stout pair of over shoes, or short boots, to draw on over [her] shoes.”

${ }^{261}$ Aaron Burr to Theodosia Burr Alston, January 22, 1802, Ibid, 170.

${ }^{262}$ Aaron Burr to Joseph Alston, March 8, 1802, Ibid, 185.
} 
"Five weeks without hearing from you! Intolerable. Now I think to repose myself in sullen silence for five weeks from this date. I know that apples and nuts will bring you out again. Thus children are moved."263

Another instance of scolding her for not writing displayed the different attitudes

regarding slaves that she no doubt faced in her new home. Theodosia Burr Alston grew

up in a home in which her father supported his slaves’ educations, a sentiment not often

shared in the plantations of the Deep South. ${ }^{264}$ Burr wrote,

"I wish you would teach half a dozen of your negroes to write; then you might lay on the sofa, and, if you would submit to the [labor] of thinking and dictating, the thing would go on.... I am now going to smoke a [cigar] and pray for you.”265

The birth of Aaron Burr Alston on May 22, 1802 changed Theodosia Burr

Alston's life forever, and not only in the typical changes attendant with becoming a firsttime mother. Nineteen-year-old Theodosia suffered an injury in childbirth, and she never regained her full health following the birth of her beloved son. Much like her mother's fate, the lack of understanding in the medical community on the particular issues facing women's health and how to diagnose and treat distinctive female maladies led to many fruitless and often painful attempts to find a cure for Theodosia Alston.

\footnotetext{
${ }^{263}$ Aaron Burr to Theodosia Burr Alston, January 22, 1801, Ibid, 170.

${ }^{264}$ Writing to nine-year-old Theodosia during his term in the Senate in Philadelphia, Burr ended his letter by mentioning that "Alexis (one of the Burr slaves then living with him in Philadelphia) often bids me to send you some polite and respectful message on his part, which I have heretofore omitted. He is a faithful, good boy. Upon our return home he hopes you will teach him to read.” Aaron Burr to Theodosia Bartow Burr, February 20, 1793, Memoirs, I: 365. Moreover, in 1804, Burr wrote to another slave, Peggy Gallatin, while he was Vice-President and living in Washington, D.C. Peggy was a slave in his New York home, as was Alexis. Burr told Peggy, "Let nothing hinder you from going to school punctually. Make the master teach you arithmetic so that you may be able to keep the accounts of the family. I am very much obliged to you for teaching Nancy (another slave). She will learn more from you than by going to school." Aaron Burr to Peggy Gallatin, January 4, 1804, Memoirs, II: 268.
}

${ }^{265}$ Aaron Burr to Theodosia Burr Alston, February 2, 1802 (her first wedding anniversary), Memoirs, II: $172-173$. 
Theodosia Burr Alston continued to refine her remarkable education during her marriage, yet, during the next decade of her life, her primary concerns were rearing her son, encouraging her husband's rising political career, and supporting her father throughout his various tribulations. The next decade brought much turmoil to both Theodosia Burr Alston and her father. Aaron Burr's period of political and personal success receded permanently. However, Theodosia's emotional and intellectual training sustained her in her darkest moments, and her unwavering fortitude and loyalty to those she loved provided yet another testament to the inestimable depth of her character and value of her example. 


\section{Chapter Three: Abigail Adams Legacies and Lessons of Republican Motherhood}

In accordance with Aaron Burr, Abigail Adams agreed with much of Mary Wollstonecraft's Vindication of the Rights of Woman. Her admiration for Wollstonecraft's defense of the female intellect inspired John to tease her for being a “disciple of [Wollstonecraft.]”266 In response to this comment, Abigail urged him to

"confess the truth, and own that when you are sick of the Ambition, the intrigues, the duplicity and the Treachery of the aspiring part of your own sex, it is a comfort and a consolation to retire to the Simplicity, the Gentleness and tenderness of the Female Character."267

Acknowledging her sex's crucial duty in rearing well-informed, conscientious, sound future citizens, Abigail maintained,

"[Every] American wife should herself know how to order and regulate her family; how to govern her domestics, and train up her children....[She] who fails in these duties does not answer the end of her creation." 268

Wollstonecraft's emphasis on educating women beyond the artificial attributes of dancing, sewing, and entertaining impressed Abigail Adams, especially in light of her lifelong association with intellectual men who supported her educational pursuits. Abigail believed, as Wollstonecraft argued, that a more serious education would better qualify women as mothers who would rear future leaders (the goal of Republican Motherhood). Abigail wrote,

\footnotetext{
${ }^{266}$ John Adams to Abigail Adams, January 22, 1794, Margaret A. Hogan and C. James Taylor, eds, My Dearest Friend: Letters of Abigail and John (Cambridge, MA: The Belknap Press of Harvard University Press, 2007), 351.

${ }^{267}$ Abigail Adams, as quoted in Charles W. Akers, Abigail Adams: An American Woman. $2^{\text {nd }}$ ed (New York: Longman, 2000), 132.

${ }^{268}$ Abigail Adams, as quoted in Ibid, 215-216.
} 
"It is very certain that a well-informed woman, conscious of her nature and dignity, is more capable of performing the relative duties of life and of engaging and retaining the affections of a man of understanding, than one whose intellectual endowments rise not above the common level.”269

Superintending the education of her children, Abigail urged them to learn from every challenge and opportunity. On one occasion, she chastened a rather presumptuous John Quincy Adams. When John Quincy complained that his teachers and classmates at Harvard disappointed his expectations, she reprimanded his hubris. Abigail advised,

"If you are conscious to yourself that you possess more knowledge upon some subjects than others of your standing, reflect that you have had greater opportunities of seeing the world...that you have never wanted a Book, but that it has been supplied to you, that your whole time has been spent in the company of Men of Literature and Science. How unpardonable would it have been in you to have been a Blockhead."270

Abigail Adams impressed upon her children the importance of lifelong learning. Because her three sons would occupy a public role in some profession following graduation from college, she wanted to ensure that each of them possessed a grounded, virtuous character and an eye towards duty, service, and honor. Thus, she maintained a close watch on their demeanors and appearances and encouraged them to take advantage of every opportunity to learn from their surroundings. She often modeled this advice during her four-year residence in Europe.

\section{Abigail in Europe}

In France, Abigail and John lived at Auteuil, a suburb of Paris for approximately ten months between the summer of 1784 and spring of 1785. During their residence at

\footnotetext{
269 Abigail Adams to F. A. Vanderkemp, February 3, 1814, Charles Francis Adams, ed, Letters of Mrs. Adams, the Wife of John Adams, vol 2, $2^{\text {nd }}$ ed (Boston: Charles C. Little \& James Brown, 1840), 274-275.

${ }^{270}$ Abigail Adams to John Quincy Adams, July 21, 1786, L. H. Butterfield, ed, Adams Family Correspondence (AFC), 8 vols (Cambridge, MA: The Belknap Press of Harvard University Press, 19632007), VII: 276.
} 
Auteuil, they enjoyed the company of Nabby and John Quincy, as well as the frequent visits of Thomas Jefferson. Abigail’s Puritan heritage caused her to criticize European mores, especially on Sundays in Paris when crowds flocked to the streets and parks for various amusements. Though she often displayed a tourist's bias, she occasionally changed her opinions after the initial shock subsided. For example, after attending the ballet in Paris, she reported,

"I felt my delicacy wounded, and I was ashamed to [be] seen to look at...[girls] dressed in the [thinnest] silk [and] Gauze,...springing two feet from the floor, poising themselves in the air, with their feet flying, and as perfectly [showing] their Garters and drawers, as [though] no [petticoat] had been worn."271

After a few performances, Abigail relaxed her concerns. She confessed, "Shall I speak a truth and say that repeatedly seeing these Dances has worn off the disgust, which I at first felt, and that I see them now with pleasure?”272

In the spring of 1785, Congress appointed John Adams as the first United States Minister to Great Britain, and he, Abigail, and Nabby prepared to move to London. John Quincy returned to the United States after a six-year absence, and he entered Harvard University that summer. With John an official member of the diplomatic corps, London society expected her to perform the official social obligations of a diplomat's wife. She feared that John's salary in comparison with much larger salaries of other nations' diplomats would embarrass their country on the national stage. Relating her frustration to Thomas Jefferson, Abigail wrote,

"[These] missions abroad, circumscribed as they are in point of expenses, place the ministers of the United States in the lowest point of view of any envoy from any other

${ }^{271}$ Abigail Adams to Mary Cranch, February 20, 1785, AFC, VI: 67.

272 Ibid. 
Court; and in Europe, every being is estimated, and every country valued, in proportion to their show and splendor."273

While she worried over John's salary and the image of the United States, she expertly managed her and John’s private finances. Much as she had during the Revolution years, Abigail sought out security for their future by planning improvements to their home and farm with her uncle Dr. Cotton Tufts. In the early days of Abigail and John's European residence, Tufts wrote to both of them on matters of their home. However, he soon only addressed such correspondence to Abigail due to John's frequent assertions that she would respond to his questions with instructions. Abigail appreciated John's confidence as well as the autonomy to act in this capacity, but she also knew it was quite an anomaly. She wrote to Tufts, “[Though I am very willing to relieve him from every care in my power, yet I think it has too much the appearance of wielding instead of sharing the scepter."274

Soon after settling into their London home at Grosvenor Square, the Adamses dealt with a delicate situation over Nabby’s engagement to Royall Tyler. Ever the candid gossips, Abigail and her elder sister Mary Cranch wrote back and forth about the implications of Tyler's strange behaviors. Although Royall Tyler boarded with the Cranches, Mary informed Abigail that she hardly saw him and that he had kept letters from Abigail and Nabby to members of the family to himself on several occasions. ${ }^{275}$

\footnotetext{
${ }^{273}$ Abigail Adams to Thomas Jefferson, February 11, 1786, Lester J. Cappon, ed, The Adams-Jefferson Letters, The Complete Correspondence between Thomas Jefferson and Abigail and John Adams, 2 vols (Chapel Hill: The University of North Carolina Press, 1959), I: 119.

${ }^{274}$ Abigail Adams to Dr. Cotton Tufts, June 24, 1785, AFC, VI: 187.

${ }^{275}$ Phyllis Lee Levin, Abigail Adams: A Biography (New York: St. Martin’s Press, 1987), 213-214.
} 
Nabby relieved Abigail of her role as undercover mother. One morning, Nabby showed her mother Tyler's vague correspondence from the past year, and intimated that she had reason to question his honor. Several days later, John gave his unqualified support to the dissolution of the relationship, and so, the romance of Nabby and Royall Tyler ended. ${ }^{276}$ No man lacking honor would receive the gift of John and Abigail Adams' daughter's hand in marriage.

As one relationship ended, another began, and by the summer of 1786, Nabby married Colonel William Stephens Smith, John's secretary in London. Nabby's marriage to Colonel Smith took a significant toll on Abigail, as Nabby had been the one continual presence in Abigail's life during all of the painful separations from John and the boys. Yet, Nabby's absence profoundly affected John as well. Late on the morning following their wedding, as Abigail prepared for their customary brunch, she responded to a knock at her parlor door. Opening her door, she confronted John, who said, "Well, I have been to see them."277

While Abigail anticipated the arrival of her first grandchild in the early winter of 1787, she grew anxious when news of Shays’ 1786 Rebellion reached London. Her reactions to this domestic conflict sparked the first seeds of tension between her and Thomas Jefferson. In her characterization of the Rebellion to Jefferson, who was still in Paris, Abigail minced no words to convey her anger. She exclaimed,

\footnotetext{
${ }^{276}$ Ibid, 215-216.

${ }^{277}$ Abigail Adams to Mary Cranch, July 4, 1786, AFC, VII: 236.
} 
"Ignorant, wrestles desperadoes, without conscience or [principles] have led a deluded multitude to follow their standard.... [Those] [mobbish] insurgents are for sapping the foundation, and [destroying] the whole [fabric] at once.,278

Jefferson's response shocked Abigail. He countered, "The spirit of resistance to government is so valuable on certain occasions, that I wish it to be always kept alive.... I like a little rebellion now and then.,279

Disagreement over the implications of Shays' Rebellion foreshadowed future tensions between Abigail Adams and Thomas Jefferson. Yet, in the meantime, Abigail recovered her composure and offered her assistance in acclimating Jefferson's youngest daughter, Maria “Polly” Jefferson to Europe. In the summer of 1787, Polly Jefferson arrived in London with an adolescent slave, Sally Hemings. To acquaint Polly and Sally to European styles, Abigail purchased clothes for both girls.

Moreover, Abigail used her love of reading to distract Polly from homesickness. Abigail reported to Jefferson, "Books are her delight, and I have furnished her out a little library, and she reads to me by the hour with great distinctness and comments on what she reads with much propriety.” In the same letter, Abigail also conveyed her attachment to the young girl. She confessed to Jefferson,

"I am really [loathe] to part with her, and she last evening upon Petit's [Jefferson's valet who had come to London to escort Polly and Sally to Paris] arrival, was thrown into all her former distresses, and bursting into Tears, told me it would be as hard to leave me as it was [to leave] her Aunt [Eppes].,280

\footnotetext{
${ }^{278}$ Abigail Adams to Thomas Jefferson, January, 29, 1787, Cappon, ed, The Adams-Jefferson Letters, I: 168.

${ }^{279}$ Thomas Jefferson to Abigail Adams, February 22, 1787, Ibid, 173.

${ }^{280}$ Abigail Adams to Thomas Jefferson, July 6, 1787, Ibid, 184.
} 
Over the course of the previous year, Abigail displayed her characteristic bias against Europe and social customs that contrasted with her deep sense of virtue. Before Nabby gave birth to her first child, who would be named William Steuben Smith, in the spring of 1787, Abigail, Nabby, and Colonel Smith visited the English resort of Bath.

During this excursion, Abigail compared her Puritan principles with the scenes of amusement surrounding her. As she had in Paris, Abigail expressed to her sister hesitation at the conventions and attitudes particular to Europe. She wrote,

"What indeed is Life or its enjoyments without settled [principles], laudable purposes, Mental exertions and internal comfort...how are these to be acquired in the hurry [and] tumult of the World?,281

Abigail's longing for home also appeared in a letter to Jefferson in which she confided,

"I will most joyfully exchange Europe for America, and my public for a private life. I am really surfeited with Europe and most heartily long for the rural cottage, the purer and honester manners of my native land, where domestic happiness reigns unrivalled, and virtue and honor go hand in hand.,282

In Europe, Abigail's commitment to Republican Motherhood found many distinct outlets. She sacrificed personal comforts by doing without the typical number of servants in a diplomatic household (due also to John's meager salary), she kept apprised of current events at home, and she remained closely involved in the activities of her children and husband. Furthermore, she provided direction and attention to young Polly Jefferson, and she continually sought for ways to improve herself. In the winter of 1787 , though she was homesick, she diverted her attention to a series of scientific lectures in London. She recognized the rarity of such study for females, though she confessed that she fervently

\footnotetext{
${ }^{281}$ Abigail Adams to Mary Cranch, January 20, 1787, AFC, VII: 448.

282 Abigail Adams to Thomas Jefferson, February 11, 1786, Capon, ed, The Adams-Jefferson Letters, I:
} 119. 
enjoyed the experience of learning something so new and exciting. She explained to her niece Lucy Cranch,

"The [five] lectures which I attended were experiments in Electricity, Magnetism, Hydrostatics, Optics, [and] Pemematics, all of which are connected with, and are subservient to the accommodation of Common Life. [It] was like going into a [Beautiful] Country, which I never saw before, a Country which our American Females are not permitted to visit or inspect.,283

In early spring 1788, Abigail and John parted with Nabby who sailed for her new home in New York with Colonel Smith and their infant son. Several weeks later, Abigail rejoiced that she and John were finally on their way home. Abigail's epitaph on her European experiences offers proof of her resounding patriotism.

"Indeed I have seen enough of the world... and shall be content to learn what is further to be known from the page of History.... Tis [Domestic] happiness and Rural felicity in the Bosom of my Native land, that has charms for me. Yet I do not regret that I made this excursion since it has only more attached me to America." 284

\section{Public Life: Abigail on the American Stage}

When Abigail and John Adams arrived in Boston in May 1788, crowds packed the local wharf and feted them with a hero's welcome. By the fall of 1788, most political observers predicted that John Adams would become the country’s first Vice-President. Indeed, the electors voted John Adams into the second highest political office in the United States, and in early 1789 John and Abigail Adams prepared for a new chapter in their lives and service to their country.

\footnotetext{
${ }^{283}$ Abigail Adams to Lucy Cranch, April 26, 1787, AFC, VIII: 25.

284 This quote is excerpted from a portion of Abigail Adams' diary, which is included in L. H. Butterfield, ed, Diary and Autobiography of John Adams (DAJA), 4 vols (Cambridge, MA: The Belknap Press of Harvard University Press, 1961), III: 215.
} 
Vice-President Adams hurried to New York City by himself in the spring to attend the opening session of the first United States Congress. However, he soon realized that he desperately needed Abigail’s presence. John rented Richmond Hill, later Aaron Burr's home, and though it provided a quiet, spacious, and comfortable retreat from his long days and numerous responsibilities, he needed Abigail's experience and oversight. He expressed his frustration in a letter in which he all but demanded that she leave Massachusetts at once.

"If you cannot borrow enough (to pay for the trip to New York), you must sell horses, oxen, sheep, [cows], [anything] at any rate rather than not come on. If, no one will take the place, leave it to the Birds of the Air and Beasts of the Field: but at all Events break up that Establishment and that Household.,285

After only arriving back in the United States eight months before, Abigail hesitated to leave Braintree. She enjoyed the company of her niece and surrogate daughter, Louisa Smith, whom she welcomed permanently into her home. Also, she relished the proximity of her sons, as John Quincy studied law in nearby Newburyport, Massachusetts, and Charles and Thomas attended classes at Harvard. ${ }^{286}$ Furthermore, she wondered how she could set off for a new home several states away with renovations underway on the home, named Peacefield, which she and John had only recently acquired. Abigail knew that John needed her, yet, for the past decade, she solely managed their home, farm, and securities. Therefore, she informed John that while she hoped to join him soon, she would certainly not "leave [Peacefield] to the Birds of the Air and Beasts of the Field.” She advised him,

\footnotetext{
${ }^{285}$ John Adams to Abigail Adams, May 14, 1789, Hogan and Taylor, eds, My Dearest Friend: Letters of Abigail and John Adams, 324.

${ }^{286}$ Levin, 252 and 256.
} 
"You must be sensible from the tenor of Your Letters that I have not known [heretofore] what to do, anymore than you have from your situation, what to direct. You will be as patient as possible and rest assured that I will do my utmost with the means I have, to [expedite] [everything].”287

Nevertheless, John employed a different strategy than bold demands to leave Massachusetts at once. He indicated that his health suffered and implied that nothing except for her presence would alleviate his affliction. On June 6, 1789, John wrote,

"I must now most seriously request you to come on to me as soon as conveniently you can. Never did I want your assistance more than at present, as my Physician and my Nurse. My disorder of Eight years standing has [increased] to such a degree as to be very troublesome and not a little alarming.,"288

Approximately one week later, the management of the Peacefield home and farm as settled as possible, Abigail, Louisa Smith, and recent Harvard graduate, Charles Adams, arrived in New York City.

New York City boasted particular domestic charms for Abigail Adams, as she once again enjoyed Nabby’s company. Already in New York, Nabby, Colonel Smith, and their two young sons moved into Richmond Hill shortly before Abigail's arrival. Nabby undoubtedly anticipated the reunion with her mother, as she had just given birth to her second child, son John Adams Smith. Though proud of John’s prominent position and joyous in the presence of her children, Abigail Adams pondered the potential repercussions of her new station. Ever cognizant of her sense of duty, Abigail worried that the enhanced public attention might somehow hinder her character. Regarding this anxiety, Abigail sought the assistance of elder sister Mary Cranch. She related to Mary,

\footnotetext{
${ }^{287}$ Abigail Adams to John Adams, May 31, 1789, Hogan and Taylor, eds, My Dearest Friend: Letters of Abigail and John Adams, 326.

${ }^{288}$ John Adams to Abigail Adams, June 6, 1789, Ibid, 328.
} 
"I have a [favor] to request of all my near and intimate [Friends]. [It] is to desire them to watch over my conduct, and if at any time they perceive any alteration in me with respect to them, arising as they may suppose from my situation in Life, I beg they would with the utmost freedom acquaint me with it.... I know mankind are prone to deceive themselves, and some are disposed to misconstrue the conduct of those whom they conceive placed above them."289

After one year in New York City, Abigail commenced the arduous task of moving once again. In a compromise over Alexander Hamilton’s financial programs, Congress voted to move the nation's capital to Philadelphia for a ten year period during the construction of a permanent capital along the Potomac River. Leaving New York meant that Abigail lost the company of her daughter, grandsons, and son, Charles, who stayed behind and studied the law. However, Abigail and John's youngest son, Thomas, soon joined them following his graduation from Harvard. He, too, planned to pursue law. ${ }^{290}$

The astute political observer, loyal wife, affectionate mother, and doting grandmother, Abigail Adams prioritized and fixated upon her home and family matters as she had all of her married life. She enjoyed observing the business of government and discussing political topics with John and her many correspondents. However, she dreaded the social duties ascribed to her role and once described them as "splendid misery. ${ }^{291}$ In the summer of 1791, Abigail and John returned to Peacefield, and set into motion the pattern of their living arrangements for the rest of John's political career.

During Congress’ adjournments, they vowed to make haste for Massachusetts. After another year in Philadelphia in 1792, Abigail and John followed their plan, though

\footnotetext{
${ }^{289}$ Abigail Adams to Mary Cranch, July 12, 1789, AFC, VIII: 388.

${ }^{290}$ Lynne Withey, Dearest Friend: A Life of Abigail Adams (New York: Simon \& Schuster, 1981), 213.

${ }^{291}$ Abigail Adams to Mary Cranch, May 16, 1797, Stewart Mitchell, ed, New Letters of Abigail Adams, 1788-1801 (Westport, CT: Greenwood Press, 1947), 87.
} 
unexpectedly, their visit home precluded Abigail's return as the Vice-President's wife to Philadelphia. On the trip back to Braintree (renamed Quincy in early 1792), Abigail fell ill. Voted to a second term as Vice-President in late 1792, John returned to the capital alone. Staying home and attending to domestic affairs preserved Abigail's health, assured the stability of their home and farm, and saved money by avoiding "the heavy expense of maintaining two households.”292

Moreover, Abigail disliked the climate—both weather and political—of Philadelphia, and she hated the incessant social obligations incumbent on a public official's wife. ${ }^{293}$ Despite the annoyances and hardships, Abigail knew she had to bear more separations from her husband and children because they faced important tasks of public service and professional growth. Nevertheless, the fact that she remained in Massachusetts during John's entire second term as Vice-President also attests to her unique iron will and determination.

During John's second term as Vice-President, the Adams brothers pursued professional advancements. Charles practiced law in New York, married one of Colonel Smith’s sisters, and started raising children of his own. Meanwhile, President George Washington nominated John Quincy as United States Minister to the Netherlands in 1794. After Congress confirmed his nomination, John Quincy and his younger brother Thomas embarked for Europe. Proud of her sons' reputation and recognition by the government, Abigail Adams also lamented their absence. However, always the grounded Republican Mother, Abigail Adams knew that her country needed her sons' talents

\footnotetext{
${ }^{292}$ Withey, 223.

${ }^{293}$ Ibid, 219-220.
} 
elsewhere. She explained to First Lady Martha Washington that "at a very early period of Life, I devoted [them] to the [public].,294

As John Quincy and Thomas Adams arrived safely in Europe, tensions between the United States, Great Britain, and France escalated on the high seas. Conveying her relief upon learning of their safety, Abigail also displayed her characteristic hope in her sons' success in service to their country. She wrote to John in early 1795,

"You will see by the papers that our sons had a fine passage.... Perilous are the Times into which they have fallen. I hope it may prove for their good and the [benefit] of their Country that they are called into Service in so critical a period.... [To] an [overruling] Providence I commend them.",295

Furthermore, in writing to her sons, she reminded them of their responsibilities and encouraged their attention towards maintaining a virtuous character abroad. She advised,

"As I consider it one of my chief blessings to have sons worthy of the confidence of their country, so I hope, in imitation of their father, they will serve it with honor and fidelity, and with consciences void of [offense]; and though they may sometimes meet with ingratitude, they will have 'The soul's calm sunshine and the heart-felt joy.',296

With John Quincy and Thomas Adams abroad, several new additions to Abigail's home and extended family provided welcome distractions. Nabby gave birth to a daughter, Caroline, in 1795. Also, in 1795, Abigail added another young female relative to her Quincy household. Abigail's younger sister's husband, John Shaw, died in late 1794. By the spring of 1795, Betsy Smith Shaw remarried and moved to New Hampshire with her new husband, Stephen Peabody. Betsy sent her eldest daughter, who shared her

\footnotetext{
${ }^{294}$ As quoted in Withey, 230.

${ }^{295}$ Abigail Adams to John Adams, January 21, 1795, Hogan and Taylor, eds, My Dearest Friend: Letters of Abigail and John Adams, 383.

${ }^{296}$ Abigail Adams to Thomas Adams, November 8, 1796, Charles Francis Adams, ed, Letters of Mrs. Adams, 233-234.
} 
name, to Abigail for a long visit. ${ }^{297}$ Abigail's maternal influence extended far beyond the confines of her nuclear family. Abigail Adams believed in the importance of setting a prime example of virtue, duty, and education at an early age not just on male children (future leaders), but also on female children (future mothers of leaders). She enjoyed Betsy Shaw’s company, as well as that of Louisa Smith. Abigail and John Adams treated Louisa Smith as their own daughter, even though John often worried that she needed to branch out from the protective roof at Quincy. He indicated this belief in a letter to Abigail in late 1794. "I pray you to take care of your health and of Louisa's too. She is a good girl: but I sometimes wish she would run about a little more if it was even to look at the young men."298

After President Washington announced his intention to retire in 1796, Abigail and John Adams prepared for yet another momentous chapter in their lives. Elected President in late 1796, John Adams achieved the pinnacle of twenty-two years in public service. After a four year break from Philadelphia, Abigail Adams planned to join her husband after his inauguration. Nevertheless, always the caretaker, she found it impossible to leave John's ailing mother, and she painstakingly prepared their home and farm for her absence. Similar to his frustrations in New York City in 1789, John grew impatient with Abigail's delay. For example, he stated,

"There are so many things to do in furnishing the house in which I want your advice, and on so many other accounts it is improper we should live in a state of

\footnotetext{
${ }^{297}$ Withey, 232.

298 John Adams to Abigail Adams, November 19, 1794, Hogan and Taylor, eds, My Dearest Friend: Letters of Abigail and John Adams, 375. Louisa Smith lived with Abigail and John Adams for the remainder of their lives and provided comfort to both of them in their last years.
} 
separation.... I am very unwell—a violent cold and cough fatigues me, while I have [everything] else to harry me: so I must entreat you to come on as soon as you can."299

Just as she had done in 1789, Abigail calmly explained that she knew he needed her, and she hoped to complete her domestic arrangements with expediency, but she reaffirmed the importance of attending to the security of Peacefield. She explained,

"I consider [Peacefield] as our [last] resort, as our Ark of safety. I think it ought not to be [suffered] to fall into decay, and I shall not [regret] any pains which I can bestow upon it to render it a retirement eligible to us when we are four years older if we should live to see the day. We have been doing and undoing all our days. I would aim at making such arrangements as would tend to make it better rather than worse."300

Since 1774 Abigail had grown accustomed to ensuring the stability of their home and financial affairs. Without John's guidance, she expertly maintained the home, farm, and investments while her husband pursued public service. Moreover, within the context of the late eighteenth century, her contemporaries would never have expected her to perform public responsibilities with John. A more conventional First Lady who reigned as a supportive wife and official hostess was the standard following Mrs. Washington. Specifically,

“The model republican woman was to be self-reliant (within limits), literate, untempted by the frivolties of fashion. She had a responsibility to the political scene, though was not active in it.... A woman's competence was not assumed to extend to the making of political decisions. Her political task was accomplished within the confines of her family., 301

In April 1797, John’s mother died, and Abigail left for Philadelphia. Shortly after her arrival, she and John learned that John Quincy married Louisa Catherine Johnson, the

\footnotetext{
${ }^{299}$ John Adams to Abigail Adams, March 27, 1797, Ibid, 443.

${ }^{300}$ Abigail Adams to John Adams, January 28, 1797, Ibid, 430.

${ }^{301}$ Linda K. Kerber, Women of the Republic: Intellect \& Ideology in Revolutionary America, (Chapel Hill: The University of North Carolina Press, 1980), 228.
} 
daughter of an “American consul in London.” Pleased with John Quincy’s marriage and son Charles’ growing family, Abigail worried about her daughter’s well-being, as Colonel Smith frequently left her alone while pursuing vague speculative ventures. In the summer of 1797, Abigail stepped in to alleviate some of Nabby's responsibilities. She arranged for Nabby's sons to move to New Hampshire and board with her sister Betsy Peabody, whose husband was a schoolmaster. Significantly, "it was Abigail who concocted the plan, worked out the details, and paid for the boys’ tuition and board.”302

By 1798, the United States stood at the brink of war with France over the XYZ Affair as well as commercial and naval tensions. Wary of war, President Adams pursued a cautious course with the French while strengthening American defenses. Abigail was resting at home in Massachusetts in 1799 when John pursued a second attempt at negotiation with the French. Many members of Congress and the press criticized his actions, or lack thereof. Some even blamed John’s negotiation strategy on Abigail’s absence from Philadelphia. John informed Abigail,

“Oh how [my critics] lament Mrs. Adams’ Absence! She is a good [Counselor]! If she had been here, Murray [the American peace commissioner] would never have been named.... This ought to gratify your Vanity enough to cure you.,303

Abigail’s “vanity,” rested in John’s triumphs, not in others' recognition of her attributes. In response to John's letter, Abigail confirmed her infinite faith in her husband's sagacity. She maintained,

"Some of the [Federalists]... said they [wished] the old woman had been there.... but the old woman can tell them they are mistaken, for she considers the measure as a

\footnotetext{
${ }^{302}$ Withey, 251.

303 John Adams to Abigail Adams, February 25, 1799, Hogan and Taylor, eds, My Dearest Friend: Letters of Abigail and John Adams, 464.
} 
master stroke of policy; knowing...that the pulse had been feeling through that minister for a long time. Besides, the appointment shows that the disposition of the Government is still pacific, and puts to the test the [sincerity] of the [Directory],... and upon them rests in the Eyes of all the world....It is a measure which strikes in the Head Jacobinism.... Pray am I a good politician?”304

Many historians have emphasized Abigail Adams’ influence upon her husband’s public career. Contemporaries often assigned her the label of "Mrs. President," though Martha Washington was known as "Lady Washington.” While Martha Washington graced the social sphere of levees and official dinners, Abigail Adams preferred her role as confidante and sounding board. "Certainly her position of chief adviser to the President was more important than her social role during the years when she was the President’s Lady."305

Although John respected Abigail’s opinions, Abigail’s public persona stayed grounded behind accepted lines of separate spheres. As a Republican Mother, her interest in public affairs primarily stemmed from her husband's and sons' involvement. Under the Republican Motherhood ideal, women were expected to attain and foster a “political education and political sensibility” while they remained entrenched in their “true place in the polis...on its edges."306

While John's pursuit of peace proved successful in 1800, his critics, and especially, the Democratic-Republicans (Jefferson’s party), gained enough strength to defeat him in his bid for re-election in 1800. Abigail traveled to the new capital in

\footnotetext{
${ }^{304}$ Abigail Adams to John Adams, February 27, 1799, Ibid, 464-465.

${ }^{305}$ Linda Grant De Pauw and Conover Hunt, 'Remember the Ladies:' Women in America, 1750-1815 (New York: The Viking Press, 1976), 146.

${ }^{306}$ Kerber, Women of the Republic, 12.
} 
Washington, D.C. to support John in his last few months in office. Family tragedy soon compounded John's election loss, as Charles Adams died at the end of the year. Charles, once a promising lawyer and happy father, became an alcoholic. His death staggered his parents, as Abigail conveyed to her sister Mary Cranch.

"Weep with me over the grave of a poor unhappy child who cannot now add [another] pang to those which have [pierced] my Heart for several years past.... He was no [man's] Enemy but his own.,307

Immediately, Abigail reached out to his widow and children. Soon after his passing, Charles' widow, Sally Smith Adams, and their two daughters, Susan and Abigail, moved in with Abigail and John in Washington, D.C. ${ }^{308}$

In February 1801, Abigail Adams returned to Quincy. She brought with her Susan Adams, Charles' eldest daughter. The Adams' retirement at Peacefield in 1801 coincided with the commencement of a remarkably active period in their domestic life. Always a perceptive observer, Abigail kept a close eye on the public world, as a Republican Mother needed to maintain an understanding of current events. Abigail Adams actively followed public events through her private lens of Peacefield, and especially, vicariously, through the rise of her son John Quincy Adams’ career. The ultimate goal of Republican Motherhood, virtuous sons serving the state and leading the Republic, never materialized in the case of Charles Adams. However, John Quincy Adams triumphantly surpassed John and Abigail Adams' expectations with a lifelong commitment to public service as a respected and accomplished politician and statesman.

\footnotetext{
${ }^{307}$ Abigail Adams to Mary Cranch, December 8, 1800, Mitchell, ed, New Letters of Abigail Adams, 261262.

${ }^{308}$ Withey, 273.
} 


\section{Family Matters and Changing Times}

John Quincy Adams, his wife, Louisa Catherine Adams, and their infant son, George Washington Adams, arrived in the United States in the fall of 1801. Upon his return to the United States, John Quincy won election to the Massachusetts legislature, and in 1803, he traveled to Washington, D.C. as a United States Senator. While his political career rose, John Quincy’s family grew to include another son, named after his father. As she had provided for Nabby’s sons’ educations, Abigail believed that John Quincy’s young boys needed a stable and supportive environment away from Washington, D.C. Louisa Catherine, however, wanted to join her husband in the nation's capital, where her family also lived.

Louisa Catherine and her sons followed John Quincy to Washington for his first year in the Senate. After Congress’s adjournment, John Quincy returned to Peacefield alone for a few months' respite. During this time, Abigail Adams and Louisa Catherine exchanged several interesting letters. The experienced Republican Mother kept a fervent eye upon the health, appearance, and conduct of her grown sons, and she believed she had a duty to instruct her daughter-in-law on such matters. On one occasion, Abigail pointed out to Louisa Catherine that she needed to take better care of John Quincy. Abigail complained that her eldest son “didn’t get enough exercise,” and “went too long without meals.”309

Further, Abigail charged that Louisa Catherine "should...get him to pay more attention to his personal appearance.”310 Abigail elaborated,

\footnotetext{
${ }^{309}$ Withey, 290.

${ }^{310}$ Ibid.
} 
"I do not wish a Senator to dress like a Beau, but I want him to conform so far to the fashion, as not to incur the Character of Singularity-nor give the occasion to the World to ask what kind of Mother he had or to charge upon a Wife negligence and inattention when she is guiltless.”311

Not to be defeated, Louisa Catherine held her own against Abigail's admonishments.

Writing to Abigail shortly after John Quincy returned from Peacefield, Louisa Catherine stated, “I was much surprised and grieved to see him look so ill when he returned.”312

After another visit to Peacefield in the summer of 1805, Louisa Catherine relented to her husband's (and mother-in-law’s) wishes and allowed her sons to remain in Massachusetts when she and John Quincy left for Washington. From the capital, Louisa Catherine informed Abigail that she felt "compelled" to part with her children.

Consequently, Abigail encouraged her to recognize the necessity of personal sacrifice for the good of her sons' futures. Abigail wrote,

"I should suppose that your own judgment, experience, and good sense would have convinced you of the propriety of the measure without compulsion. I have experienced separations of all kinds from children equally dear to me and know how great the sacrifice and how painful the task-but I considered it the duty of a parent to consult the interest and benefit of their children." 313

Despite the strained first few years of their relationship, Abigail Adams and Louisa Catherine Adams eventually warmed to each other. Their rapport especially improved when Louisa Catherine started residing at Peacefield in the fall of 1806 while her husband returned to the Senate.

\footnotetext{
${ }^{311}$ Abigail Adams to Louisa Catherine Adams, December 8, 1804, Adams Papers (Boston: Massachusetts Historical Society, 1958), Reel 403.

312 Louisa Catherine Adams to Abigail Adams, as quoted in Cokie Roberts, Ladies of Liberty: The Women Who Shaped Our Nation (New York: Harper Collins, 2008), 113.

${ }^{313}$ Abigail Adams to Louisa Catherine Adams, January 16, 1806, Adams Papers, Reel 404.
} 
During John Quincy's term in the Senate, Abigail’s youngest son, Thomas, married a local woman, Nancy Harrod, and the newlyweds moved in with their in-laws for what would be a five year residence. By 1810, Thomas enjoyed a respectable law practice and felt confident that the time had arrived when he and his wife and three young

children should find a home of their own. ${ }^{314}$ Meanwhile, Nabby's husband and eldest son became involved in a venture to liberate part of Spain's American colonies under the leadership of revolutionary leader, Francisco de Miranda. The venture failed miserably, and Colonel Smith faced a trial in the summer of 1806 for high misdemeanor (ironically, exactly one year before Aaron Burr would face similar charges). Though acquitted of the charges, Colonel Smith lost a government post that he had secured under the Jefferson Administration. ${ }^{315}$

Following Colonel Smith’s trial, Nabby and her daughter, Caroline, went to Quincy for a long visit with Abigail and John. Abigail and John worried about their only daughter's well-being for many years before their son-in-law finally established himself professionally. Occasionally in Colonel Smith's absences, Nabby and her children spent months with Abigail and John. Abigail's sense of duty and sacrifice influenced Nabby, as she often remained isolated at home waiting for her husband's return. In spite of his professional troubles, Colonel Smith slowly recovered his reputation and even gained election to Congress. Ironically, as he finally settled in to a stable career, he also faced personal tragedy with his wife's diagnosis of cancer.

\footnotetext{
${ }^{314}$ Withey, 292-293.

${ }^{315}$ Ibid, 293-294.
} 
As his brother-in-law faced public scorn for his involvement in the Miranda affair, John Quincy Adams suffered the scorn of many members of his party. Though he entered the Senate as a Federalist in 1803, by 1808, John Quincy Adams changed sides. Due to his support of Jefferson's Louisiana Purchase and Embargo Act, the Massachusetts legislature refused to re-elect him to a second term in the Senate. John Quincy Adams resigned from the Senate before the 1808 election, and Abigail praised his bravery in following his own voice despite the ramifications. She maintained that John Quincy’s loyalty to a sense of duty and ingrained principles inspired her to revere him as “a family trophy." Further, she proclaimed that she "[prided] herself more in being the Mother of such a son, than in all the [honors] and titles which [a] monarch could bestow." 316

\section{Beginnings and Endings}

Because of his support of key legislation in the Jefferson Administration, John Quincy Adams received another diplomatic appointment in 1809. President James Madison nominated John Quincy as Minister to Russia, the country where he had first honed his skills as a future diplomat in the early 1780s. When he and Louisa Catherine and their third child, infant son Charles Francis Adams, left for Russia in the summer of 1809, Abigail assumed the primary responsibilities for their two other children. Soon after they arrived in St. Petersburg in late 1809, Louisa Catherine indicated that they faced economic difficulties due to John Quincy’s modest salary. ${ }^{317}$

\footnotetext{
${ }^{316}$ Abigail Adams to Nabby Adams, August 29, 1808, as quoted in Levin, 431.

${ }^{317}$ Withey, 300.
} 
Abigail Adams understood Louisa Catherine’s concerns, as she and John faced similar circumstances during their years in Europe and the nation's capital. Therefore, Abigail interceded on John Quincy's behalf and wrote to President Madison about her son’s difficult circumstances. Without John Quincy's knowledge, his mother requested that the President recall him from Russia. Madison responded to Abigail's letter, and he affirmed that he never intended "to subject [John Quincy] to the personal sacrifices which he finds unavoidable, [and] he will not, in retiring from them, impair the sentiments which led to his appointment.”318

Madison then wrote to John Quincy and indicated that in light of Abigail's intimation that John Quincy faced dire financial consequences abroad, Madison would recall him if necessary, though he hoped this might be avoided. Madison explained that he believed the "peculiar urgency manifested in [Abigail’s letter] was rather hers, than yours. ${ }^{319}$ John Quincy never intended to vacate his post. He and Louisa Catherine surmounted their initial hardships, and he related to Abigail in 1811, "I know that your letter to the President was written from the tenderest and most affectionate concern for myself and my family. ${ }^{320}$

At the same time that John Quincy expressed his gratitude for Abigail's “tenderest and most affectionate concern," his sister Nabby suffered from breast cancer. In the summer of 1811, Nabby Adams Smith traveled to Massachusetts for medical attention. The physicians eventually determined that she needed a mastectomy, which she endured

\footnotetext{
318 James Madison to Abigail Adams, August 15, 1810, Adams Papers, Reel 410.

${ }^{319}$ James Madison to John Quincy Adams, October 16, 1810, Ibid.

${ }^{320}$ John Quincy Adams to Abigail Adams, June 30, 1811, Ibid, Reel 411.
} 
in her parents' home in the fall of that year. Though she appeared to recover, by 1813, the cancer returned. In July 1813, Nabby’s son John Adams Smith and devoted daughter, Caroline, escorted her to Peacefield where she wished to spend her last days. Nabby died several weeks later. ${ }^{321}$

Nabby's death occurred two years after the death of Abigail's closest confidante, her elder sister, Mary Cranch. Two years following Nabby's death, Abigail’s younger sister Betsy died. Abigail found some comfort in the presence of her niece Louisa Smith and granddaughter, Susan Adams, who still lived with her. Mourning her mother, Caroline Smith chose to live with Abigail until her marriage in 1814. When Caroline left Peacefield, Abigail wrote, "She was the prop of my Age, my solace, my comfort.”322

Although surrounded by a stream of losses, Abigail Adams took immense pride in John Quincy's expanding array of achievements. During his second term as President, James Madison appointed John Quincy Adams as Minister to Great Britain. Markedly, John Quincy paralleled his father's public career in many respects. They both served as diplomats in the Netherlands and Great Britain, and after working as a peace commissioner during the War of 1812, he shared with his father the distinction of signing a treaty ending hostilities with Great Britain. ${ }^{323}$

Abigail Adams resolved to live out her final years with her natural propensity for activity. Writing to John Quincy in 1816, John Adams conceded that Abigail "must take upon herself the Duties of Granddaughter, [Niece], Maids, Husband and all. She must be

\footnotetext{
${ }^{321}$ Withey, 302, 306.

${ }^{322}$ Abigail Adams to Elizabeth Shaw Peabody, September 13, 1814, Adams Papers, Reel 419.

${ }^{323}$ Levin, 471.
} 
[always] writing to you and all her Grand children.”324 In 1817, President James Monroe appointed John Quincy Adams as Secretary of State. John Quincy, Louisa Catherine, and their three children (the two oldest boys went to London in 1815 after John Quincy became Minister to Great Britain) returned to Quincy in the summer.

After John Quincy and Louisa Catherine left for Washington, D.C. in the fall, their children renewed their studies in Massachusetts. George Washington Adams went to Harvard, and John and Charles Francis Adams prepared for college in Boston. ${ }^{325}$ Abigail continued her tradition of supervising her grandchildren's academic progress, as they visited her and John most weekends out of every month. The Republican Mother turned Republican Grandmother believed that she needed to "wean them by degrees."326 Thus, nearing her seventy-third birthday, Abigail Adams still prioritized her influence upon her children and grandchildren.

During the summer of 1818, John Quincy and Louisa Catherine spent a month in Quincy with Abigail and John. Soon after they left for Washington, they learned that Abigail fell dangerously ill. Louisa Smith and Susan Adams held vigil at Abigail’s bedside and attempted to comfort John. Three days after her fifty-fourth wedding anniversary, Abigail Adams died. When word arrived in Washington, John Quincy struggled to compose his anguish. As Abigail’s eldest son, John Quincy Adams shared a deep bond with his mother.

\footnotetext{
${ }^{324}$ John Adams to John Quincy Adams, June 26, 1816, Adams Papers, Reel 432.

${ }^{325}$ Withey, 312.

${ }^{326}$ Abigail Adams to Louisa Catherine Adams, September 15, 1817, Adams Papers, Reel 439.
} 
Separated from Abigail during his adolescence, college years, and especially, during his diplomatic posts, John Quincy cherished his mother’s advice, influence, and support of his education, travels, and political involvements. He often prioritized writing to her or visiting her and John over all other concerns or persons in his life. For example, when he and his family arrived in Philadelphia in 1801, John Quincy instantly traveled alone hundreds of miles to Massachusetts instead of first accompanying his wife and young son to his in-laws' home in much-closer Washington, D.C. ${ }^{327}$

In a poignant letter John Quincy expressed to his father the magnitude of Abigail's influence upon all of their lives. "The pangs of dissolution are past; and my Mother, I humbly hope is a Spirit, purified even from that little less than heavenly purity, which in her existence here was united with the lot of mortality.”, ${ }^{228}$ Furthermore, he recognized Abigail's significance to his generation as well as to posterity. John Quincy eulogized, "Her life gave the lie to every libel on her sex that was ever written."329

\section{Legacies and Lessons}

"My dear, I did not marry you to share in the sunshine of life and desert you when clouds gathered above us. ${ }^{\text {,30 }}$

In the tense few months leading up to the outbreak of the Civil War, Mary S.

Logan, the wife of an Illinois Congressman, assured her husband that she would share in

\footnotetext{
${ }^{327}$ Withey, 284-285.

${ }^{328}$ John Quincy Adams to John Adams, November 2, 1818, Hogan and Taylor, eds, My Dearest Friend: Letters of Abigail and John Adams, 478.

${ }^{329}$ John Quincy Adams, as quoted in Charles W. Akers, Abigail Adams: An American Woman. 2nd ed (New York: Longman, 2000), 219.

${ }^{330}$ Mary S. Logan, The Part Taken by Women in American History, (Wilmington, DE: The Perry-Nalle Publishing Company, 1912), 6.
} 
all of the trials he expected to face upon the outbreak of war. Though separated by several generations from Abigail Adams, Mrs. Logan’s eloquent testament of loyalty embodied the principal dynamic of Abigail's commitment to her husband, family, and country. During the Adams’ marriage,

"Abigail... 'never by word or look' discouraged John from 'running all hazards for the salvation' of his country's liberties....[She] [was] willing to share with him, and...encouraged their children to share with both of them 'in all the dangerous consequences [they] had to hazard."’331

Despite flattering assurances by male contemporaries of her intelligence, perception, and management, Abigail Adams never aspired to subsume John’s public status nor his role as the primary head of household, farm, and children. On one occasion, she expressed shock and embarrassment upon learning that a Quincy town councilman quoted her in a speech. Exasperated, she wrote to her sister, Mary Cranch,

"I could not believe that any Gentleman would have had so little delicacy or so small sense of propriety as to have written a mere vague opinion and that of a Lady to, to be read in a [public] assembly as an authority. The Man must have lost his senses.",332

Similarly, she wrote to John Quincy in 1796,

“However brilliant a woman's [talents] may be, she ought never to shine at the [expense] of her Husband. Government of States and Kingdoms, [though] God knows badly enough managed, I am willing should be solely administered by the Lords of the Creation....I shall only contend for [Domestic] government, and think that best administered by the Female.",333

In her later years, Abigail reiterated her support for the separate spheres of the sexes. She

\footnotetext{
${ }^{331}$ John Adams to Caroline De Windt, July 12, 1820, as quoted in Levin, 488. Caroline Smith De Windt was Nabby's only daughter and one of Abigail's favorite grandchildren. She lived with Abigail and John following her mother's death in the summer of 1813 until her marriage in late 1814. See Withey, 306.

${ }^{332}$ Abigail Adams to Mary Cranch, June 6, 1797, Mitchell, ed, New Letters of Abigail Adams, 96.

333 Abigail Adams to John Quincy Adams, May 20, 1796, Adams Papers, Reel 381.
} 
argued, "I believe nature has assigned to each sex their particular duties and sphere of action, and to act well their part, 'there in all the honor lies.'”334

Abigail Adams appeared at foreign courts, garnered respect from prominent male public figures, and wrote with great depth and accuracy about the political and social issues of her day. Yet, her utmost pride rested in her marriage to John and the lives of her children. The ultimate Republican Mother, Abigail's example of one who sacrificed so much personal happiness so often and for so long deserved the designation as "the leading woman of the Revolution.” Strikingly, such a designation rests upon her laurels as a wife and most significantly, as a mother. In her domestic kingdom, she reigned supreme. She affirmed to John,

"[As] Reigning and Ruling [by a woman] is so much out of fashion, at the present day, my ambition will extend no further that Reigning in the Heart of my Husband. That is my Throne and there I aspire to be absolute.,335

The primacy of her maternal influence at such impressionable stages in her children’s development and at such impressionable stages in the development of the new nation coincided with remarkable significance and surely led to the perpetual legacies of educational achievement, public service, and sacrifice evident in the Adams' lineage.

\footnotetext{
${ }^{334}$ Abigail Adams to F. A. Vanderkemp, February 3, 1814, Charles Francis Adams, ed, Letters of Mrs. Adams, 274-275.

${ }^{335}$ Abigail Adams to John Adams, February 26, 1794, Hogan and Taylor, eds, My Dearest Friend: Letters of Abigail and John Adams, 362.
} 


\section{Chapter Four: Theodosia Burr Alston Legacies and Lessons of Republican Motherhood}

While her upbringing differed distinctively from that of Abigail Adams,

Theodosia Burr Alston's willingness to sacrifice for the good of her community and

futures of those closest to her emulated the tenets of Republican Motherhood so

pronounced in Abigail Adams’ life. Theodosia Burr Alston, a product of the

Revolutionary generation, proved what contemporary leaders had envisioned with the

Republican Mother ideal.

"Believing as they did that republics rested on the virtue of their citizens, Revolutionary leaders had to believe not only that Americans of their own generation displayed that virtue, but that Americans of subsequent generations would continue to display the moral character that a republic required." 336

\section{Marriage and Motherhood}

"Delicacy and debility are sometimes fascinating when affected by a coquette adorned with the freshness of health-but a pale, thin, face, sunken, instead of languishing eyes, and a form evidently tottering, not gracefully bending, never, I suspect, made, far less could they retain a conquest or even please a friend. I therefore encourage spirits, try to appear well and am rewarded.”337

Following Aaron Burr Alston’s (Gamp) birth in late May of 1802, Theodosia’s

heath suffered. She indicated years later that "a severe [labor] produced a prolapsus,”

and "ever since, [I] [have] been suffering with the remains of that distressing complaint.” ${ }^{338}$ Aaron Burr immediately took Theodosia, Gamp, and one of Theodosia’s

\footnotetext{
${ }^{336}$ Linda K. Kerber, Women of the Republic: Intellect \& Ideology in Revolutionary America (Chapel Hill: The University of North Carolina Press, 1980), 199.

${ }^{337}$ Theodosia Burr Alston to Aaron Burr, March 17, 1803, Mary Jo Kline, ed, The Papers of Aaron Burr, Series I: Correspondence, Reel V: Frame 497. (This letter, manuscript number 3541, is included in the Burr Collection at Yale University Library, New Haven, CT.)

${ }^{338}$ Theodosia Burr Alston to Dr. William Eustis, October 3, 1808, Ibid, Reel VI: Frame 430. (This letter, manuscript number 3202, is included in the Fuller Collection at Princeton University Library, Princeton, NJ.)
} 
sisters-in-law to New York to escape the stifling heat and humidity of the South Carolina summer. Joseph stayed behind, as he was campaigning for the South Carolina Legislature. When she reached New York, Theodosia visited Ballston Spa, a popular mineral springs resort, to bathe in the waters in the hopes of relieving her painful symptoms.

Throughout the summer of 1802, Theodosia visited the springs often, however, this practice failed to produce a cure, as she indicated to her sister-in-law, Frances Prevost. In one letter she related, “[I] found myself [recently] somewhat [swollen] round the waist... and a horrible sensation like a spike running up me worried me all day yesterday.”339 Several weeks later, Theodosia relented, "I have not been [able to adopt] any method that promises me relief....The use of cold water has never been of service or disservice to me- - I use it constantly without any effect. ${ }^{340}$

Despite the severe pain of her condition in the summer of 1802, Theodosia remained devoted to her father's company and the care of her infant son, while also inquiring about Joseph's health and campaign. She wrote Joseph long and heartfelt letters during her six-month stay in New York. In one particular letter, Theodosia conveys her unqualified support for her husband's burgeoning political career.

"How does your election advance? I am anxious to know something of it; not from patriotism; however. It little concerns me which party succeeds. Where you are, there is my country, and in you are [centered] all my wishes. Were you a Brutus, I should be a Roman. But were you a Caesar, I should only wish glory to Rome that glory

\footnotetext{
${ }^{339}$ Theodosia Burr Alston to Frances Ann Prevost, July 18, 1802, Ibid, Reel V: Frame 248. (This letter, manuscript number 2222, is included in the Burr Collection at the New York Historical Society, New York, NY.)

${ }^{340}$ Theodosia Burr Alston to Frances Ann Prevost, August 6, 1802, Ibid, Frame 259. (manuscript number 2223 in the Burr Collection at the New York Historical Society)
} 
might be yours. As long as you love me, I am nothing on earth but your wife and your friend; contented and proud to be that."341

Another letter displayed her concern for Joseph’s health amidst her own suffering.

"You are ill. You have been imprudent, and all my fears are fulfilled. Without anyone near you to feel for you, to attend to you, to watch every change and share every pain. Your wife only could do that.... It is she only who forgets herself in you, and who, in gratifying your wishes and alleviating your pain, serves the interest nearest her heart."342

Reflecting on Joseph's health, Theodosia speculated on the cause of summer illnesses, especially in the hot and humid southern climate. She presented him with her advice on

how to avoid future sicknesses.

"During the night, [vapors in the air] become so condensed that you perceive in them every blast (of scent). It is said that the fever in Charleston does not arrive from that, but the filth of the streets are quite enough to make one think otherwise. Perhaps I am wrong in my reason and opinion.... Montesquieu says he writes to make people think; and why may not Theodosia?”343

In her most significant letter written from New York in the summer of 1802, Theodosia confessed to Joseph that she knew she would never be cured. In

\footnotetext{
${ }^{341}$ Theodosia Burr Alston to Joseph Alston, September 3, 1802, Matthew L. Davis, ed, Memoirs of Aaron Burr with Miscellaneous Selections from his Correspondence (Memoirs), 2 vols (New York: Harper \& Brothers, 1836), II: 207-8.

${ }^{342}$ Theodosia Burr Alston to Joseph Alston, September 30, 1802, Ibid, 212. Theodosia is reminiscent of Abigail Adams writing to John in 1782, "[If] I can add to your Happiness—is it not my duty—if I can soften your Cares - is it not my duty? - if I can by a tender attention and assiduity prolong your most valuable Life-is it not my duty?” Abigail Adams to John Adams, September 4, 1782, L. H. Butterfield, ed, Adams Family Correspondence (AFC), 8 vols (Cambridge, MA: The Belknap Press of Harvard University Press, 1963-2007), IV: 376.

${ }^{343}$ Theodosia Burr Alston to Joseph Alston, June 26, 1802, Memoirs, II: 202-203. Theodosia invoked her father's tone in this letter to Joseph. When she was seventeen, Burr praised her for her character and commitment to her studies. "At your age, to prefer duty to pleasure when they are in collision is a degree of firmness rarely exhibited, and, therefore, the more calculated to inspire respect. I perceive that I am not very explicit; but you will reflect and discern my meaning. Montesquieu said he wrote to make people think, and not make them read—and why may not Aaron Burr.” Aaron Burr to Theodosia Bartow Burr, January 30, 1800, Ibid, I: 401-402.
} 
acknowledgement of this unfortunate reality, she exhibited remarkable patience,

fortitude, personal sacrifice, all at the age of nineteen.

"I have now abandoned all hope of recovery. I do not say it in a moment of depression, but with all my reason about me. I am [endeavoring] to resign myself with cheerfulness; and you, also, my husband, must summon up your fortitude to bear with a sick wife the rest of your life.... The great misfortune of this complaint is, that one may vegetate forty years in a sort of middle state between life and death, without the enjoyment of one or the rest of the other. You will now see your boy in a few days....He is a sweet little rascal. If Heaven grant him but to live, I shall never repent what he has cost me." 344

Theodosia's resolve to live carried her through many precarious moments of sickness. In the winter 1803, she relapsed after returning to South Carolina, yet, several months later, she wrote Burr to report of her recovery.

“The whole family, as well as myself, had begun to think pretty seriously of my last journey.... But, on recovering a little, I kicked off my blisters, and declared I would be dressed; be carried in the open air, and have free use of cold water. I was indulged.... I am again getting well... The secret is, that my constitution is good. I exert myself to the utmost." 345

Similar to Abigail Adams, Theodosia Burr Alston loved activity. She never allowed sickness to defeat her, and she believed that engaging in various projects and interests preserved her life.

"My health is infinitely improved, and I attribute it to nothing but the continual bustle I have been kept in for three weeks past. What a charming thing a bustle is.... It gives a circulation to the blood, an activity to the mind, and a spring to the spirits."346

Upon Joseph’s successful election to the South Carolina Legislature in 1802, he found several months to accompany Theodosia and Gamp for their annual trip north. The

\footnotetext{
${ }^{344}$ Theodosia Burr Alston to Joseph Alston, October 30, 1782, Memoirs, II: 213.

345 Theodosia Burr Alston to Aaron Burr, March 17, 1803, Ibid, 220-221.

346 Theodosia Burr Alston to Aaron Burr, December 1, 1803, Ibid, 251.
} 
Alstons, including several of Joseph's relatives, left for New York in the summer of 1803. Traveling through Washington to visit Burr, Theodosia visited Dolley Madison and Secretary of the Treasury, Albert Gallatin and his wife. She reported to Burr,

"Mrs. Madison and myself have made an interchange of visits today. She is still pretty; but oh, that unfortunate propensity to snuff-taking. We drank tea with Mr. and Mrs. Gallatin by invitation. Nobody asked us to eat.,347

When she returned to South Carolina in the fall of 1803, Theodosia found brief, if any, respite from her journey, as she and Joseph still lived with Joseph’s brother and sister-in-law due to slow progress of renovations at their Oaks plantation home. Theodosia commented that "[the] lazy workmen have been wasting their time, and have not yet finished what two Northern workmen could have done in a month. ${ }^{348}$ In any case, Theodosia made the most of her surroundings, and her attentions to Gamp consumed much of her time—as did answering Burr's incessant inquiries about his grandson.

Aaron Burr envisioned remarkable accomplishments for the child. In accordance with her upbringing, Theodosia valued education, and she sought to follow Burr's academic advice with enthusiasm and attention to detail. Burr told Theodosia, "If little

\footnotetext{
${ }^{347}$ Theodosia Burr Alston to Aaron Burr, October 16, 1803, Ibid, 242. That Theodosia mentioned "nobody asked us to eat" could indicate that she was aware of Burr's isolation from the Jefferson Administration. Burr had mentioned as much just one year into his term as Vice-President. He wrote to Joseph Alston, "I dine with the president about once a fortnight, and now and then meet the ministers in the street. They are all very busy; quite men of business. The Senate and the Vice-President are content with each other, and move on with courtesy.” Aaron Burr to Joseph Alston, March 8, 1802, Ibid, 185.

${ }^{348}$ Theodosia Burr Alston to Aaron Burr, November 8, 1803, Ibid, 244. This sentiment is similar to one expressed by Abigail Adams upon her arrival to Washington, D.C. late 1800. Observing various construction projects of the new capital city, Abigail informed her uncle Dr. Cotton Tufts, "Two of our hardy New England men would do as much work in a day as the whole [twelve] (slaves), but it is true Republicanism that drives the slaves half fed, and destitute of [clothing]...to [labor], whilst the owner walks about idle.” Abigail Adams to Dr. Cotton Tufts, November 28, 1800, as quoted in Lynne Withey, Dearest Friend: A Life of Abigail Adams (New York: Simon \& Schuster, 1981), 277.
} 
gamp could read, I should write to him volumes. I find my thoughts straying to him every hour in the day, and think of him twenty fold than of you two (her and Joseph) together. „349 Two months later, he mapped out a course of study for the nineteen-month old Gamp.

"You do not say whether the boy knows his letters. I am sure he may now be taught them, and then put a pen into his hand, and set him to imitate them. He may read and write before he is three years old. This with speaking French, would make him a tolerably accomplished lad of that age, and worthy of his blood.”350

Abigail Adams believed Burr's fascination with every detail of his grandson was extreme. She wrote to Mary Cranch, "You would think to hear him that no man in the world had ever been a grandfather before.”351

Burr's pride beamed in letters to Theodosia, and he frequently asserted that Gamp possessed “genius.” In one such letter Burr requested, “Tell dear little gampy that I have read over his letter a great many times, and with great admiration. Mrs. Law, to whom I showed it, thinks it is a production of genius”352 In a similar letter, Burr said, "Of all earthly things. I most want to see your boy. Does he yet know his letters? If not, you surely must want skill, for, most certain, he can’t want genius.”353 Burr’s preoccupation with Gamp’s education also related to his concern for Theodosia’s knowledge.

\footnotetext{
${ }^{349}$ Aaron Burr to Theodosia Burr Alston, November 7, 1803, Memoirs, II: 245.

${ }^{350}$ Aaron Burr to Theodosia Burr Alston, January 17, 1804, Ibid, 269.

${ }^{351}$ As quoted in Milton Lomask, Aaron Burr: The Years from Princeton to Vice-President, 1756-1805 (New York: Farrar, Straus, Giroux, 1979), 329.

${ }^{352}$ Aaron Burr to Theodosia Burr Alston, December 4, 1803, Memoirs, II: 247-248.

353 Aaron Burr to Theodosia Burr Alston, May 8, 1804, Ibid, 287.
} 
Specifically, Burr urged Theodosia, "Pray take immediately in hand some book which requires attention and study. You will, I fear, lose the habit of study, which would be a greater misfortune than to lose your head." ${ }^{354}$ Always an astute learner, Theodosia consistently pursued personal improvement during her marriage. Yet, as a wife, mother, plantation mistress, and in light of her recurring illnesses, she did not pursue subjects with the same avidity as in her youth. Regardless of her new stations as wife and mother, Burr believed that her intellect needed constant occupation for her own improvement, a view many of his contemporaries would not have shared.

For example, in 1804 he requested that she commence "a French translation of the Constitution of the United States.” He conceded that this project would provide “a great [labor] to you; but I cannot get it done here, and it may not be useless to you to burnish up your French a little.”355 One of the most significant examples of Theodosia's pursuit of intellectual advancement was her idea to compose children's stories about ancient history. Burr avidly supported such an endeavor. He affirmed,

"Your idea of dressing up pieces of ancient mythology in the form of amusing tales for children is very good.... Send your performances to me, and, within three weeks after they are received, you shall have them again in print. This will be not only an amusing occupation, but a very useful one to yourself.... Nathalie, too, must work at it, and I'll be that she makes the best tale. I will be your editor and your critic.”356

\footnotetext{
${ }^{354}$ Aaron Burr to Theodosia Burr Alston, December 4, 1803, Ibid, 248.

${ }^{355}$ Aaron Burr to Theodosia Burr Alston, January 17, 1804, Ibid, 269. Most likely, Theodosia never completed this task, if she started it at all. No mention of this translation is mentioned in her subsequent letters to Burr.

${ }^{356}$ Aaron Burr to Theodosia Burr Alston, June 24, 1804, Ibid, 290. Burr loved to tease Theodosia about his esteem for Nathalie d'Lage Sumter. He kept this up as a sort of competition between them, though in a jovial manner. After Nathalie's marriage to a prominent South Carolina politician, Burr wrote to her, "I perceive, and with pleasure, that I shall pass much of my time in South Carolina, and shall divide it between you and Theodosia, but the mountains are my [favorite] residence. Which is my favorite daughter, I have not yet been able to decide.” Aaron Burr to Nathalie d'Lage Sumter, July 5, 1802, Ibid, 205-206.
} 
Although Aaron Burr proved that females possessed equal capabilities of intellectual achievement as men, he never encouraged Theodosia to use her education to destroy existing barriers to women's entrance into the public arena. Though he undoubtedly believed that she could shine in a position of public leadership, he encouraged her marriage and emphasized the importance of her role as a mother. His letter to Joseph Alston on the eve of his duel with Hamilton conveys sentiments also espoused by advocates of Republican Motherhood. If Joseph continued to encourage the Theodosia's education, the resulting advantages would extend from Theodosia, to Joseph, and most importantly, to Gamp. Burr appealed,

"Let me entreat you to stimulate and aid Theodosia in the cultivation of her mind. It is indispensable to her happiness and essential to yours. It is also of the utmost importance to your son. She would presently acquire a critical knowledge of Latin, English, and all branches of natural philosophy. All this would be poured into your son. If you would differ with me...suffer me to ask it of you as a last [favor]. ${ }^{3557}$

\section{Looming Clouds and Various Trials}

In the summer of 1804, Aaron Burr fought the infamous duel with Alexander Hamilton, and the following year, he embarked on a westward excursion for which he would eventually be tried for treason. Theodosia Burr Alston worried about her father's predicaments and his future, yet, he, always her teacher, soothed her anxieties and steered her towards the courageous fortitude she had developed since childhood. After he was indicted for misdemeanor (breaking anti-dueling laws) in New York and murder in New Jersey (as Burr's fatal shot occurred in Weehawken, New Jersey), he downplayed the

Unfortunately, Theodosia never pursued this endeavor. Her father's troubles escalated soon after his letter supporting the idea, and her health wavered dangerously over the course of the next year.

${ }^{357}$ Aaron Burr to Joseph Alston, July 10, 1804, Ibid, 326. 
magnitude of the charges against him. "You treat with too much gravity the New Jersey affair. It should be considered as a farce, and you will yet see it terminated so as to leave only ridicule and contempt to its abettors." ${ }^{358}$

As Burr finished his term as Vice-President and even presided over an impeachment trial in the Senate despite his existing indictments, Theodosia's health crumbled. Evidently, signs of an impending collapse appeared to her father, who wrote in the spring of 1805, "I fear that you are suffering a debility, arising from climate or

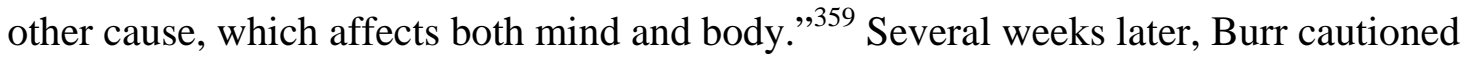
that "your milk diet will not carry you through the summer." Furthermore, she needed to change her bathing habits. "Bathing in seawater is a grand preservative. If your bath be in the house, the best time is an hour or two before dinner. Tepid bath; none of your cold baths for a machine such as yours." ${ }^{360}$

A few months later, Aaron Burr wandered throughout the western territories, while in South Carolina, Theodosia believed she was dying. On August 6, 1805 she wrote a pseudo-will in a long letter to Joseph, who left earlier that morning for the Legislature. Characteristic of the Republican Mother, Theodosia demonstrated sound presence of mind, calm resignation, and a preeminent concern with the future of her son. She wrote, "Something whispers [to] me that my end approaches. In vain I reason with

\footnotetext{
${ }^{358}$ Aaron Burr to Theodosia Burr Alston, January 22, 1805, Ibid, 355. For details of the indictments charged against Burr, see Nancy Isenberg, Fallen Founder: The Life of Aaron Burr (New York: Viking Penguin, 2007), 267-268.

${ }^{359}$ Aaron Burr to Theodosia Burr Alston, March 10, 1805, Memoirs, II: 358.

${ }^{360}$ Aaron Burr to Theodosia Burr Alston, March 29, 1805, Ibid, 366.
} 
myself; in vain I occupy my mind, and seek to fix my attention on other subjects.” ${ }^{\text {361 }}$ She delineated which articles of clothing and trinkets Joseph should offer to his sisters, Nathalie d'Lage Sumter, and other close relatives.

Her next request might not have sat well with Joseph, who owned over 200 slaves and may have been uncomfortable with her wishes - though he never left a record of his opinions regarding the treatment of slaves. Theodosia urged, "Write immediately to New York, forwarding some money for the comfortable support of Peggy (one of Burr's slaves) until my father can provide for her. Do not permit grief at the loss of me to render you forgetful of this. ${ }^{362}$ She asked that Joseph heed only his instincts with Gamp. “Never, never listen to what any other person tells you of him. Be yourself his judge on all occasions.... Desist not an instant from your endeavors to secure his confidence.”363

After addressing her belongings, her concern for Peggy, and Gamp’s upbringing, Theodosia displayed her humility and willingness to accept her fate. She told Joseph,

"Death is not welcome to me. I confess it is ever dreaded. You have made me too fond of life....He who is wisdom itself ordains events; we must submit to them. Least of all should I murmur. I, on whom so many blessings have been showeredwhose days have been numbered by bounties - who had such a husband, such a child, and such a father."364

Fortunately, Theodosia recovered, and a year later, she concentrated on Gamp’s health. Gamp contracted a fever in the spring of 1806, and Theodosia immediately set out for the north for the first time in three years in the hopes of restoring Gamp’s health. Her plan

\footnotetext{
${ }^{361}$ Theodosia Burr Alston to Joseph Alston, August 6, 1805, Ibid, 439.

${ }^{362}$ Ibid, 440.

${ }^{363}$ Ibid.

${ }^{364}$ Ibid, 441.
} 
succeeded, as Aaron Burr reported to his new friend and associate Harman Blennerhasset. "I leave here (Bedford Springs, PA) my daughter and her son, who have both greatly profited by the use of the waters, or, what is perhaps more probable, by the north air.”365

Harman Blennerhasset and his wife Margaret supported Aaron Burr’s plans to establish a settlement on the Washita River in the Louisiana Territory and mount a private invasion, called a filibuster, into Spanish Mexico if and when the United States declared war on Spain. ${ }^{366}$ Both Harman and Margaret possessed cultivated intellects and pursued studies in fine arts, science, philosophy, and literature. By late August 1806, Joseph joined Theodosia and Gamp, and they visited Blennerhasset Island after Burr proceeded west. Theodosia and Margaret developed a friendship from this visit, as they each shared common attributes and interests. ${ }^{367}$ The Alstons left Blennerhasset Island after a few days and returned to South Carolina for Joseph’s attendance at the Legislature.

In February 1807, federal authorities arrested Aaron Burr in Alabama and escorted him to Richmond, Virginia to face charges of treason and high misdemeanor. For over a year, press reports, anonymous warnings, and letters from public officials announced that Aaron Burr planned to "divide the nation,” overthrow the government, and conduct an unlawful invasion of Mexico. ${ }^{368}$ In late 1806, however, General James

\footnotetext{
365 Aaron Burr to Harman Blennerhasset, August 15, 1806, The Papers of Aaron Burr, Reel VI: Frame 182. (This letter, number 123, is included in the Blennerhasset Papers at the Blennerhasset Island Historical State Park archives, Parkersburg, WV.)

${ }^{366}$ Milton Lomask, Aaron Burr: The Years of Exile, 1805-1836 (New York: Farrar, Straus, Giroux, 1982), 111-112.

${ }^{367}$ Ibid, 224-225.

${ }^{368}$ Lomask, Aaron Burr: The Years of Exile, 1805-1836, 199.
} 
Wilkinson, who suggested the plan of a filibuster to Burr, betrayed Burr, fabricated evidence, and falsely informed President Jefferson of a “deep, dark and [widespread] conspiracy.” In January 1807, Jefferson ordered Burr's arrest and then proclaimed Burr's guilt as "beyond question."369

Back in South Carolina, Theodosia despaired for her father’s safety and his future. Yet, Burr counseled patience, reflection, and of course, study. He advised,

"You have read to very little purpose if you have not remarked that such things happen in all democratic governments. Was there in Greece or Rome a man of virtue and independence, and supposed to possess great talents, who was not the object of vindictive and unrelenting persecution? Now, Madame, I pray you to amuse yourself by collecting and collating all the instances to be found in ancient history, which you may connect together, if you please, in an essay, with reflections, comments, and applications. This I may hope to receive about the $22^{\text {nd }}$ of May.",370

Summoning Theodosia to his trial in Richmond in the summer of 1807, Burr insisted, "I beg and expect it of you that you will conduct yourself as becomes my daughter, and that you manifest no signs of weakness or alarm.”371 Burr also expressed how valuable Theodosia's presence would be to him in the coming weeks. He sought her judgment and opinions above all others at this precarious time.

"I want an independent and discerning witness to my conduct and to that of the government. The scenes which have passed and those about to be transacted will exceed all reasonable credibility....unless attested by very high authority.....If absent, you will suffer great solicitude. In my presence, you will feel none, whatever may be the malice or the power of my enemies, and in both they abound., ${ }^{372}$

\footnotetext{
${ }^{369}$ Ibid, 172, 199.

${ }^{370}$ Aaron Burr to Theodosia Burr Alston, April 26, 1807, Memoirs, II: 405.

${ }^{371}$ Aaron Burr to Theodosia Burr Alston, June 24, 1807, Ibid, 408.

${ }^{372}$ Aaron Burr to Theodosia Burr Alston, July 24, 1807, Ibid.
} 
Theodosia, Joseph, and Gamp arrived in Richmond in late July 1807. One month later, John Marshall ruled in favor of Burr's acquittal since the prosecution's witnesses and submitted evidence failed to prove that he engaged in an "overt act of war" as specified by the Constitution. ${ }^{373}$ Elated by the victory, Theodosia informed her sister-inlaw, Frances Prevost, of the good news and provided further testament of her unwavering commitment to her father’s reputation. Theodosia maintained, “The knowledge of my father's innocence, my ineffable contempt for his enemies, and the elevation of his mind have kept me above any sensations bordering upon depression.”374 Although Burr’s acquittal at Richmond relieved Theodosia, her celebration was short lived.

\section{The Years of Separation}

By the spring of 1808, creditors pressed Aaron Burr incessantly. Acquitted at Richmond but scorned in the press and bereft of any immediate solution to his financial quandaries, Aaron Burr prepared to leave the country for an extended self-imposed exile. Once again in ill health, Theodosia roused herself to join Burr in New York for his last days on American soil. She and Gamp arrived in late May 1808 and summoned all of her courage to face his departure with stoicism. Her poise impressed Burr, and he commented,

"Make haste...to gather strength for the occasion (of my departure). Your efforts on the late one were wonderful. God grant that they may not have exhausted you. Don't cry, dear, for your loss. It would go to mar.",375

\footnotetext{
${ }^{373}$ Lomask, Aaron Burr: The Years of Exile, 1805-1836, 280.

374 Theodosia Burr Alston to Frances Ann Prevost, September 1, 1807, as quoted in Richard N. Cote, Theodosia Burr Alston: Portrait of a Prodigy (Mount Pleasant, SC: Corinthian Books, 2002), 244.

375 Aaron Burr to Theodosia Burr Alston, May 1808, Matthew L. Davis, ed, The Private Journal of Aaron Burr during his Residence of Four Years in Europe with Selections from his Correspondence (PJAB), 2 vols (New York: Harper \& Brothers, 1838), I: 20.
} 
Burr set sail in early June and arrived safely in England in July. On the day he embarked for Europe, Theodosia planted a false story in the local papers indicating that Burr traveled to Canada. She would intercede for his safety often over the next four years.

After Burr left for Europe, Theodosia settled into New York, though she never found much comfort or solace due to her illness and sense of isolation. She indicated this sense of isolation to Burr in the fall of 1808.

"Except myself, all your friends are well. But the world begins to cool terribly around me. You would be surprised how many I supposed attached to me have abandoned the sorry, losing game of disinterested friendship., 376

Theodosia withstood her share of the brunt of popular animosity toward her father. After an encounter with a former friend, Theodosia related the marked change in this friend's demeanor.

"Mrs. - had even the cruelty to tell me that I had been so long ill and so long friendless, that I could not feel as keenly as others would; and, if I did, I should have remained at home; not moved about the world helpless and dependent on others....But she is like all the rest of the world. They like to display hospitality without suffering inconvenience. They like to have a character for sensibility; but why wait with tender patience on a sick friend, when the desired character is so easily obtained by pronouncing a few fine sentences in a dressing-room arm chair?’377

During her ten month stay in New York, Theodosia sought medical advice from several prominent physicians. In a candid letter to Dr. William Eustis, her father's close friend, Theodosia catalogued the history and nature of her illness. She detailed the long list of harrowing and often gruesome effects of her sicknesses, all stemming from her labor in 1802. Theodosia suffered from sharp pains, an irregular menstrual cycle, nervous "afflictions," rheumatism, loss of appetite, vomiting, fevers, in addition to

\footnotetext{
${ }^{376}$ Theodosia Burr Alston to Aaron Burr, September 30, 1808, Ibid, 58.

377 Theodosia Burr Alston to Aaron Burr, May 31, 1809, Ibid, 243.
} 
"hysteric fits [with] various [colors] and flashes [of ] light before the eyes, figures

[traipsing] round [the] bed, strange noises, low spirits, and worse, much worse than all, periods of inconceivable irritability and impatience.” Furthermore, she noticed a swollen thyroid gland and a tumor in her abdomen. ${ }^{378}$

In seeking Dr. Eustis’ advice, Theodosia emphasized her inability to execute her domestic duties fully. In the image of Abigail Adams and cognizant of her responsibilities and sense of obligation as a virtuous Republican Mother, Theodosia explained to Dr. Eustis, "[I] [dread] of becoming incurable and most [desire] to be once more active and useful., ${ }^{379}$ In a follow-up to this letter only three days later, Theodosia continued this theme.

"Sure, at my age [25] recovery is to be expected under such auspices. Oh yes, you will restore me to health, to enjoyment, to all the pleasing duties of domestic life. This deadened heart will once more beat with rapture, when my boy runs to my arms. I shall, again, dwell with delight on the beauties of nature, and enter with zeal in all my former interesting occupations.",380

Upon conferring with physicians in London, Burr wrote to Theodosia, Joseph, and her American physicians to argue his case for her traveling to Europe for treatment. He explained to Joseph, "[The doctors] unite with me in the opinion that the only chance of saving her is a sea voyage, and a total and immediate change of climate.” Moreover, Gamp would obviously join her, and Burr affirmed, "The boy will be educated with the children of General Bentham [son of renowned philosopher Jeremy Bentham, whom Burr

\footnotetext{
${ }^{378}$ Theodosia Burr Alston to Dr. William Eustis, October 3, 1808, The Papers of Aaron Burr, Reel VI: Frame 430. (This letter, manuscript number 3202, is included in the Fuller Collection at Princeton University Library, Princeton, NJ).

${ }^{379}$ Ibid.

${ }^{380}$ Theodosia Burr Alston to Dr. William Eustis, October 6, 1808, Ibid, Frames 435-436. (manuscript number 3203 of the Fuller Collection).
} 
befriended in England]... who are incomparably the best educated children I have ever seen. ${ }^{381}$

While Burr planned for her arrival in Europe, Theodosia tried mercury in her hopes for a cure. She remembered the experiences of her mother, who also used mercury (along with hemlock), and she hesitated to use the substance. The mercury failed to provide any relief, and several months after initiating the practice, she conveyed its failure to her father.

“[The mercury] has received a trial of more than three months' duration without having produced any sensible effect. My health, I believe, has returned thus much by the help of a naturally good constitution; a mind more at ease, a bracing climate; rather in spite of the mercury than by its assistance. I will not take anymore mercury. It renders abortive the advantages of climate, ruins my teeth, and will destroy my constitution. There is little doubt in my mind that perfect health will soon return., ${ }^{382}$

Amidst her attempts for a cure and the sense of isolation from former friends, Theodosia’s fortitude and character never faltered. She vowed many years before to "exert [herself] to the utmost.... encourage spirits, [and] try to appear well” whenever she faced sickness or adversity. ${ }^{383}$ She wanted to set an example of strength through adversity, humility, and attention to duty and self-improvement for Gamp. Accordingly, after she read Bentham's Traites de Legislation, she offered to translate the piece into English. She wrote to her father, "Does Jeremy Bentham mean to publish [it] in

\footnotetext{
${ }^{381}$ Aaron Burr to Joseph Alston, November 10, 1808, PJAB, I: 82-84. Theodosia never sailed to Europe, as Burr's credit evaporated in America, and thus, she could not finance her trip overseas. Further, her health slightly improved for several months at a time between 1809 and 1810. More importantly, Burr was ordered to leave England and spent over a year traveling across Europe to any port that would take him.

382 Theodosia Burr Alston to Aaron Burr, February 1809, Ibid, 158-159.

383 Theodosia Burr Alston to Aaron Burr, March 17, 1803, Memoirs, II: 221.
} 
English?... If he does not...I should like to have the [honor] of becoming his

translator., 384

In addition to her plan to translate Bentham's essay, Theodosia kept abreast of

public affairs as she watched for signs of war with the British over commercial and naval

tensions. Her concern over an impending war stemmed from fears for Burr's safety

abroad, which prompted her to attempt to secure her father's safe return to the United

States. Similar to Abigail Adams' efforts to intercede on John Quincy's behalf through

President James Madison, Theodosia sought the intercession of former friend, First Lady

Dolley Madison. Furthermore, Theodosia also contacted Albert Gallatin, Madison’s

Secretary of the Treasury. Addressing Dolley Madison, Theodosia wrote,

"I...request that you will, in my name, apply to the President for a removal of the prosecution now existing against Aaron Burr.... [What] policy can require the absence of my father at present?...For bereft of fortune, of popular favor, and almost of friends, what could he accomplish?...Why is he driven from his friends, from an only child, to pass an unlimited time in exile, and that, too, at an age when others are reaping the harvest of past toils?...Mr. Alston is ignorant of the step I have taken in writing to you, which, perhaps nothing could excuse but the warmth of filial affection. If it be in error, attribute it to the [indiscreet] zeal of a daughter whose soul sinks at the gloomy prospect of a long and indefinite separation from a father almost adored, and who can leave nothing unattempted, which offers the slightest hope of procuring him redress. ${ }^{\text {„385 }}$

\footnotetext{
${ }^{384}$ Theodosia Burr Alston to Aaron Burr, December 5, 1808, PJAB, I: 114. Bentham and Burr wholeheartedly supported Theodosia's proposal, and she initiated the work, though she never finished due to a relapse of her sickness.

${ }^{385}$ Theodosia Burr Alston, as quoted in Charles Burr Todd, The True Aaron Burr: A Biographical Sketch (New York: A.S. Barnes \& Company, 1908), 68-69. Theodosia's letter to Dolley is not included in The Papers of Aaron Burr or Burr's Memoirs and Private Journal. However, Theodosia's indication of Dolley's reply is located in The Papers of Aaron Burr. Charles Burr Todd was a Burr descendent, and though he did not include a bibliography in this particular source, the text of Theodosia's letter as presented here, is similar to the text of her letter to Albert Gallatin, written two years later and also included in the Private Journal and The Papers of Aaron Burr. To Gallatin, Theodosia questioned, "Must [my father] ever remain thus excommunicated from the participation of domestic enjoyments and the privileges of a citizen; aloof from his accustomed sphere, and singled out as a mark for the shafts of calumny? What benefit to the country can possible accrue from the continuation of this system? Surely it must be evident to the worst enemies of my father, that no man, situated as he will be could obtain any undue influence, even supposing him desirous of it.” Theodosia Burr Alston to Albert Gallatin, March 9, 1811, PJAB, II: 155-156. Gallatin never replied.
} 
Theodosia informed Burr in early 1811 that Dolley’s "answer was full of friendship, but nothing more. She says that nothing is in [President Madison's] power, and that she regrets it."386

As Burr faced mounting obstacles in Europe, Theodosia faced mounting tensions with her in-laws. She often conveyed disaffection with them over the years, but now she encountered treatment similar to that of the woman in New York who scolded her for burdening others. She confided to Burr,

"The family make me endure frequent vexations, but my husband is not to be swayed by their machinations, or moved by their [endeavors] to persuade him that, the more dear he is, the more hateful must I be; I, who have occasioned him so many hours of pain. This is not directly and openly expressed, but often insinuated."387

Theodosia's vast intellect and ungendered educational background assuredly distinguished her from her Southern in-laws and neighbors. Furthermore, her father's troubles inspired most contemporaries’ cool treatment. Yet, Theodosia carried on with resolve and refused to allow her health, anxieties about her father, and problems with her in-laws to interfere with her roles as a mother, wife, and daughter.

True to form, Theodosia achieved her goal of influencing Gamp’s educational progress. During his four-year European residence, Theodosia kept her father apprised of Gamp’s achievements. In particular, while living in New York throughout 1808 and 1809, Theodosia sought Burr’s advice on introducing Gamp to studying history.

\footnotetext{
${ }^{386}$ Theodosia Burr Alston to Aaron Burr, January 6, 1811, PJAB, II: 119. A year lapse in receipt of letters from her father occurred during 1810. During this time, Burr continued to face opposition in Paris to his request for a passport out of the country and back to the United States. Also, Theodosia's health relapsed.

${ }^{387}$ Theodosia Burr Alston to Aaron Burr, May 10, 1811, Ibid, 161.
} 
"In your great world is there no such thing as some easy introduction to history? The little volume sent will be valuable in its place; but I believe it important to begin with the earliest periods, and come down regularly."388

Burr disagreed with her plan, and explained, "Let your boy read history and biography of a style suited to his years. The order is of no consequence.... By-and-by, when he shall come to read more in detail, the order may be material.”389 Theodosia took Burr’s advice, and she indicated that Gamp would "read history as you approve. It is best because fragments may be selected to suit his present capacity, to excite his taste, to form and elicit his character." 390

Just as Abigail exemplified Republican Motherhood to children outside of her immediate family circle, Theodosia sought to maintain a relationship with her namesake niece, the daughter of her step-brother, Bartow, and his wife, Frances Ann Prevost. Frances died unexpectedly in late 1807, and Theodosia hoped that Bartow would bring the young Theodosia to South Carolina to live with her aunt for awhile. ${ }^{391}$ Referring to her niece as “my daughter,” Theodosia contended,

"I have great faith in the lasting effects of moral education and am desirous that no time should be thrown away in commencing hers. There will be a tutor in our family, and I intend that the two children (young Theodosia and Gamp), the tutor, and myself should speak French only.,392

\footnotetext{
388 Theodosia Burr Alston to Aaron Burr, October 31, 1808, Ibid, I: 77-78.

389 Aaron Burr to Theodosia Burr Alston, April 11, 1809, Ibid, 194.

390 Theodosia Burr Alston to Aaron Burr, August 31, 1809, Ibid, 288.

${ }^{391}$ Dorothy Smith Valentine, “`An Intercourse of the Heart’: Some Little-Known Letters of Theodosia Burr,” New York Historical Society Quarterly, vol. 37, no. 1 (January 1953), 52-53.

392 Theodosia Burr Alston to John Bartow Prevost, February 21, 1809, The Papers of Aaron Burr, Reel VI: Frame 565. (This letter, manuscript number 4932 is included in the private collection of Mrs. James H. Durgin). No record of Bartow’s daughter's proposed visit to Theodosia in South Carolina exists.
} 
As soon as she returned to South Carolina in the spring of 1809, Theodosia enhanced Gamp's education with the subjects of her youth. Theodosia wrote to her father, "My boy continues devotedly attached to you. His education advances. He reads and speaks French with facility. Reads English well, and begins with Latin this day.”393 By 1811, Theodosia proudly report to Burr, "Gampillo (age nine) drinks your health everyday and everywhere. We have procured a good preceptor for him and his progress is worthy of his blood. He, too, has written to you often."394 In the same letter, Theodosia referred to an apparent loss of letters to Burr that occurred when the British captured the ship bearing them. Recounting this loss, Burr invoked the same tenor of fascination with Gamp as he had expressed during the boy's infant years.

"Since I have heard that he had written to me, I have sent inquiries to Sweden, to Denmark, to [Hamburg], and, in short, ransacked all Europe, but to no purpose. No doubt they have got into the hands of Napoleon through some of his agents, and that he thinks them too precious to be given up., ${ }^{395}$

\section{Fate, Tragedy, and Mystery}

In the summer of 1811, Aaron Burr finally secured a passport out of France and engaged passage on a ship bound for the United States from the Netherlands. Only one day into its journey, the British captured it, and escorted it under arrest to an English naval yard. The London government allowed Burr to re-enter the country, though he faced several more months of delays before he could once and for all return to the

\footnotetext{
${ }^{393}$ Theodosia Burr Alston to Aaron Burr, August 1, 1809, PJAB, I: 284.

${ }^{394}$ Theodosia Burr Alston to Aaron Burr, February 14, 1811, Ibid, II: 140.

${ }^{395}$ Aaron Burr to Theodosia Burr Alston, February 6, 1812, Ibid, 324.
} 
States. ${ }^{396}$ Waiting in London, Burr contemplated Gamp’s future education. He worried that the boy needed a more assiduous, consistent exposure to challenging curriculum after Theodosia expressed concern for Gamp’s sporadic restlessness. She wrote,

"At times he is seized with a singular kind of torpor; a heavy listlessness, which it is impossible to remove, because every weapon strikes without effect, and becomes incapable of producing any sensation. These fits do not last a day at a time, and, as he is naturally lively, I can attribute them to nothing but seclusion. He needs companions to excite emulation in [labor] and hilarity at play., 397

When Burr reached the United States in early May 1812, he specified his

concerns for Gamp. He stated,

"None of the sports of youth to enliven his leisure hours! No emulation! No example! No association in his [labors]!...It is now that he should begin to imbibe that knowledge of the world so essential in democratic governments, and which can only be acquired by mingling with his equals on equal terms....[As] soon as I shall be settled in New York, send me the boy and his tutor. They must both live with me. The college in New York has excellent teachers in every branch....I shall superintend his studies and his pursuits of every kind....If, indeed, it be resolved that he is to do nothing in this world but drive negroes and plant rice, the present plan may do well enough; but even then I should pity the poor little fellow, for all the dull, irksome, unsatisfactory drudgery he must undergo."398

Had Burr arrived in the United States in late 1811 when he set sail from the Netherlands, perhaps one tragedy could have been avoided.

For the past several years, Theodosia, Joseph, and Gamp retreated to a mountain home in Grenville [sic] during the summer months. In early summer 1812, with America at war with Great Britain, Joseph served as a Brigadier-General in the South Carolina

\footnotetext{
${ }^{396}$ Isenberg, 384-386.

${ }^{397}$ Theodosia Burr Alston to Aaron Burr, May 10, 1811, PJAB, II: 161.

${ }^{398}$ Aaron Burr to Theodosia Burr Alston, May 9, 1812, Ibid, 395-396.
} 
militia. Consequently, the Alstons departure for the mountains occurred later than usual. Theodosia informed Burr on May 16, 1812,

"Gamp is well; his little soul warms at the sound of your name. His health has been better since we adopted the plan of residing at Grenville [sic] during the summer, though we do not go early enough. We leave this (Charleston) the latter end of June.”399

The Alstons never arrived in Grenville [sic], and Aaron Burr never enjoyed the certain pleasure of his grandson’s presence with him in New York. On June 30, 1812 Aaron Burr Alston died at the age of twelve years, two months, and eight days. He caught a fever, possibly malaria or yellow fever, and he succumbed to the illness quickly. Forlorn, Theodosia lamented to her father,

"There is no more joy for me, the world is a blank. I have lost my boy, my child is gone. My head is not sufficiently collected to say anything further. May Heaven by other blessings make you some amends for the noble grandson you have lost." ${ }^{400}$

Writing to Burr soon after Theodosia, Joseph despaired,

"That boy, on whom all rested; our companion, our friend —he who was to have transmitted down the mingled blood of Theodosia and myself-he who was to have redeemed all your glory, and shed new luster upon our families - that boy, at once our happiness and our pride, is taken from us — is dead....Theodosia has endured all that a human being could endure; but her admirable mind will triumph. She supports herself in a manner worthy of your daughter.",401

A month later, Theodosia displayed her innate dignity and strength in a letter that evoked devastation at her loss, but also symbolized her commitment to duty and family. Theodosia wrote to Burr,

\footnotetext{
399 Theodosia Burr Alston to Aaron Burr, May 16, 1812, Ibid, 398.

${ }^{400}$ Theodosia Burr Alston to Aaron Burr, July 12, 1812, The Papers of Aaron Burr, Reel VII: Frame 8. (This letter, manuscript 2690, is included in Burr collection at the American Antiquarian Society, Worcester, MA).

${ }^{401}$ Joseph Alston to Aaron Burr, July 26, 1812, Memoirs, II: 426-427.
} 
"I do live, but how does it happen?... Of what service can I be...with a body reduced to premature old age, and a mind enfeebled and bewildered? Yet, since it is my lot to live, I will [endeavor] to [fulfill] my part, and exert myself to my utmost, though this life must henceforth be to me a bed of thorns.... I can offer nothing in return [of your affection] but the love of a broken, deadened heart, still desirous of promoting your happiness, if possible." 402

As circumstances intervened to delay Burr's return to the United States and the Alstons’ departure for the South Carolina mountains, the War of 1812 delayed Theodosia’s journey to reunite with her father. In August 1812, Theodosia informed Burr that she and Alston would "probably [embark] for New York in August." war necessitated Joseph’s presence in his home state, and in December 1812, Joseph became South Carolina’s Governor. Aaron Burr asked his close friend, Dr. Timothy Greene, to travel to Charleston and accompany Theodosia to New York. Greene arrived in Charleston in late November 1812 and reserved passage aboard the Patriot, a “schooner used as a pilot boat,” known for “"excellence and swiftness in sailing [which] would ensure passage of not more than five or six days. "’404 On New Year’s Eve, 1812, Joseph Alston escorted Theodosia and Dr. Greene to Georgetown and bade farewell to his ill and somber, but stoic, wife. Several hours later, the Patriot disappeared at sea. ${ }^{405}$

\footnotetext{
${ }^{402}$ Theodosia Burr Alston to Aaron Burr, August 12, 1812, PJAB, II: 439-40.

${ }^{403}$ Ibid, 440.

${ }^{404}$ Cote, 262-263.

${ }^{405}$ Many writers, reporters, and historians have speculated about the fate of the Patriot and its occupants. Rumors of pirate attacks envisioned Theodosia's death at the end of a plank. Richard Cote presented the "Mystery of the Nag's Head Portrait," in his 2002 biography of Theodosia. This portrait is thought by some to be Theodosia Burr Alston. In the 1860s a physician in Nags Head, North Carolina received the portrait as a gift from an elderly woman, widowed for many years. Her husband was one of the "wreckers," "a shadowy, ragtag group of residents of the Outer Banks...[whose] livelihood depended on salvaging anything useful from the hulls of ships cast up—or lured onto- the shores.” The widow claimed her husband found the portrait amidst the wreckage of a ship with no passengers, which washed up on the Outer Banks in early 1813. No evidence proves the portrait is Theodosia Burr Alston, and no evidence exists that the Patriot may have washed up near Nags Head. While the woman in the portrait possesses
} 


\section{Legacies and Lessons}

In an era of limited opportunities for women, Theodosia Burr Alston, as her father's “fair experiment,” proved that the negative, contemporary assumptions of female education needed substantial revision. Some writers have scorned Aaron Burr's intensive pedagogy for his daughter, but she savored her education and continuously refined her intellect, first under his careful tutelage, and then on her own as an adult (though often by his advice).

When Burr encountered difficulties in Europe, Theodosia expressed how impressed she was with his ability to stem adversities.

"I witness your extraordinary fortitude with new wonder at every misfortune. Often, after reflecting on this subject, you appear to me so superior, so elevated above all other men; I contemplate you with such a strange mixture of humility, admiration, reverence, love, and pride, that very little superstition would be necessary to make me worship you as a superior being: such enthusiasm does your character excite in me. When I afterward revert to myself, how insignificant do my best qualities appear. My vanity would be greater if I had not been placed so near you; and yet my pride is our relationship. I had rather not live than not be the daughter of such a man."

Burr reciprocated Theodosia's admiration of and loyalty to him. He often expressed that she, in turn, was the rock upon which his ultimate happiness rested. Writing to Joseph

some similar traits to Theodosia Burr Alston, she does not share a definite resemblance. Thus, the story of the portrait remains today a "mystery." See Cote, 307-310, 313-314, 324-327. The most probable cause of the Patriot's disappearance was a massive storm, well-documented in contemporary accounts, which occurred off the coast of North Carolina in early 1813. Historian James L. Michie extensively researched early nineteenth century British naval "logbooks," in which he found many accounts of "a terrible storm which began off the Carolina coast late on Saturday afternoon, January 2, 1813, and continued well into Sunday." Michie also mapped out the Patriot's supposed course, and "plotted its likely position as just North of Cape Hatteras when the gale was at its fiercest." Michie hypothesized, "If the ship managed to escape this battering, which continued into midnight, it then faced near hurricane-force winds in the early hours of Sunday. Given this knowledge, the Patriot probably sank between 6 p.m. Saturday and 8 a.m. Sunday.” James L. Michie, as quoted in Cote, 273-274. Incidentally, Aaron Burr and Joseph Alston believed that this type of scenario claimed Theodosia's life.

${ }^{406}$ Theodosia Burr Alston to Aaron Burr, August 1, 1809, PJAB, I: 283. 
Alston the night before his duel with Hamilton, Burr stated, "I commit to you all that is most dear to me-my reputation and my daughter.”407

Even before the duel destroyed his reputation and led him to pursue opportunities that ended in his treason trial, Burr, as a popular and powerful Republican political strategist, former Senator, and current state assemblyman, freely praised Theodosia’s talents and blatantly emphasized her importance. Burr wrote to a fifteen-year-old Theodosia in 1799,

"Determination and perseverance in every laudable undertaking is the great point of difference between the silly and the wise. It is essentially a part of your character, and requires but an effort to bring it into action. The happiness of my life depends on your exertions; for what else, for whom else do I live?"408

Regardless of her advanced education, Theodosia Burr Alston never expected a public role in her society. As Abigail Adams, a woman above her time, Theodosia was also a woman of her time. Theodosia's willingness to sacrifice individual happiness and comfort, devotion to educating her son, virtuous character, loyalty to family, and lifelong pursuit of self-improvement qualified her as a Republican Mother in the second generation of the American Republic. Necessity often forced her into the public consciousness, as mistress of her father's household, as a spectator at Burr's inauguration and at his federal treason trial, as the collector of his funds and keeper of his personal and political papers during his European years, as an intercessor for his return to the United States, and as the wife of a state legislator-turned-governor.

\footnotetext{
${ }^{407}$ Aaron Burr to Joseph Alston, July 10, 1804, Memoirs, II: 326.

${ }^{408}$ Aaron Burr to Theodosia Bartow Burr, January 4, 1799, Ibid, I: 397.
} 
Theodosia Burr Alston never questioned her suitability, based on her sex, for any of these critical public duties. She accepted that as an educated, virtuous, and loyal American, daughter, mother, and wife, she was qualified for whatever role destiny presented her. Theodosia's successes in these specific public duties verified the progress that the Republican Motherhood ideal eventually portended: “The process of defining woman’s proper role...signaled American society’s growing comprehension of woman’s importance within a sphere far wider than a private household or a marital relationship."409

${ }^{409}$ Mary Beth Norton, Liberty's Daughters: The Revolutionary Experience of American Women, 1750-1800 (Boston: Little, Brown, and Company, 1980), 298. 


\section{Conclusion}

Abigail Adams and Theodosia Burr Alston displayed disinterested patriotism by sacrificing personal comforts for the benefits of their families and country. During John Adams’ twenty-seven years (1774-1801) in public service, Abigail Adams guided her children's upbringing by overseeing their education, discipline, social development, personal affairs, and career plans. John trusted Abigail with their children and home, and respected her as his most loyal supporter. At the age of eight, Theodosia Burr became her mother’s nurse and hostess of her father's home. During the next two decades, she promoted her father's ambitions, guarded his reputation, supported her husband's political career, and guided her son's education.

. Abigail Adams and Theodosia Burr Alston lived in primarily urban, upper-class environments, possessed impressive intelligence, and enjoyed companionate marriages with influential husbands. In her popular Gleaner series, Judith Sargent Murray discussed women’s suitability for education, argued against early marriages, and encouraged female pride and esteem in general. One of Murray’s most compelling statements regarding her belief in women's potential accentuated the significance of Abigail Adams and Theodosia Burr Alston. In Gleaner essay seventeen, Murray wrote,

"I would give my daughters every accomplishment which I thought proper; and, to crown all, I would early accustom them to habits of industry and order: They should be taught with precision the art economical; they should be enabled to procure for themselves the necessaries of life; independence should be placed within their grasp; and I would teach them 'to reverence themselves.",410

\footnotetext{
410 Judith Sargent Murray, The Gleaner: A Miscellaneous Production, in Three Volumes by Constantia (Boston: I. Thomas \& E.T. Andrews, 1798), 168.
} 
Abigail Adams and Theodosia Burr Alston "reverenced themselves” by high standards of public service and personal conduct. They nurtured their intelligence by pursuing knowledge and self-improvement. Further, they admitted a love of action and aspired to be useful to others. Most importantly, they emphasized the primacy of being mothers. Though a generation separated Abigail and Theodosia, social norms remained rigid to the extent that women were not encouraged to occupy public professions or roles on a grand scale. Therefore, they achieved the full goal of Republican Motherhood in the sphere in which it was intended: motherhood.

\section{Significance of Abigail Adams and Theodosia Burr Alston}

Jean-Jacques Rousseau said that “a brilliant wife is a plague to her husband, her children, her friends, her [servants], everyone.” Further, he maintained that “[outside] her home she is always ridiculous and very justly criticized.” He concluded that "women of great talent never impress anyone but fools." ${ }^{\text {411 }}$ On the contrary, Abigail Adams and Theodosia Burr Alston impressed many prominent public male figures, and each inspired them with appreciation for their character and intellect.

Abigail corresponded with Sam Adams, Elbridge Gerry, Thomas Jefferson, James Madison, James Monroe, and Benjamin Franklin, socialized with foreign diplomats, and received a formal audience at St. James' Palace. Theodosia Burr Alston corresponded and socialized with Dr. William Eustis, Jeremy Bentham, Joseph Brant, Washington Irving, James Madison, Albert Gallatin, New York mayor, Edward Livingston, and painters John Vanderlyn and Gilbert Stuart. This rather distinguished and incomplete list of admirers,

\footnotetext{
411 Jean-Jacques Rousseau in Allan Bloom, ed, Emile, or On Education (1762) (New York: Basic Books, Inc., Publishers, 1979), 409.
} 
social acquaintances, and correspondents of Abigail Adams and Theodosia Burr Alston represents anything but a collection of fools.

As Abigail Adams and Theodosia Burr Alston inspired many members of their generations, they also paved the way for future female leaders in spite of many generations of continued struggle. Contemporary essayist “Alphonzo” described the challenges facing women who attempted to achieve greater public achievement in areas traditionally reserved for men.

"The same principle which excludes a man from an attention to domestic business, excludes a woman from law, mathematics, and astronomy. Each sex feels a degree of pride in being best qualified for a particular station, and a degree of resentment when the other encroaches upon their privilege." ${ }^{412}$

Fortunately, the "degree of resentment” aimed at the accomplishments of a Sandra Day

O’Connor, the first American female Supreme Court Justice, a Winifred Edgerton Merrill, the first American female to earn a Ph.D. in mathematics, or a Sally Ride, the first American female astronaut has diminished in recent decades.

Continuing his contention for women's exclusion from "law, mathematics, and astronomy,” “Alphonzo” elaborated,

"To be lovely then you must be content to be women; to be mild, social and sentimental — to be acquainted with all that belongs to your department-and leave the masculine virtues and the profound reaches of study to the province of the other sex.."413 Just as Abigail Adams and Theodosia Burr Alston were, Justice O’Connor, Dr. Merrill, and Dr. Ride are assuredly "content to be women.” They are also "content to be women”

\footnotetext{
412 “Alphonzo,” “An Address to the Ladies,” American Magazine, vol 1, issue 4 (New York: March 18, 1788), 244.

${ }^{413}$ Ibid, 244-245.
} 
who just happen to soar to the "profound reaches of study" for the progress and future of legal, academic, and scientific advancements.

The Revolutionary generation highlighted specific virtues that modern historians define as intrinsic to the Republican Mother. Contemporaries viewed the "model republican woman" as "competent and confident," as well as "rational, benevolent, independent, and self-reliant.."${ }^{\text {"14 }}$ During many points in their lives, Abigail and Theodosia exhibited these attributes. As Republican Mothers, they contributed to the success of the republican experiment, which depended upon "an independent, virtuous, watchful, and dispassionate citizenry [guarding] against the weakness and corruption that threatened liberty." ${ }^{415}$ Though both women occupied a domestic sphere and accepted its limitations, they made room for a future expansion of this sphere.

As Republican Mothers, Abigail and Theodosia received "considerable autonomy within...the 'women's sphere,' and Republican Motherhood helped to create both the legitimacy and the solidarity necessary for later, more successful, feminist agitation." ${ }^{416}$ For more than two centuries since the American Revolution, millions of women have continued to "[transcend] the domestic realm," while at the same time expertly managing domestic duties. Women have succeeded in improving their educations, rearing active

\footnotetext{
${ }^{414}$ Linda K. Kerber, “Daughters of Columbia: Educating Women for the Republic, 1787-1815,” in Jean E. Friedman and William G. Shade, eds, Our American Sisters: Women in American Life and Thought (Lexington, MA: D.C. Heath and Co.), 1982, 42.

${ }^{415}$ Paula Baker, "The Domestication of Politics: Women and American Political Society, 1780-1920," American Historical Review, vol. 89, no. 3 (June 1984), 623.

${ }^{416}$ Ruth M. Bloch, “American Feminine Ideals in Transition: The Rise of the Moral Mother, 1785-1815,” Feminist Studies 42 (1978), 120.
} 
and invested citizens, supporting their family’s goals while pursuing their own, and inspiring others in society by examples of courage, fortitude, strength, and faith.

Contemporary writers claimed that the duties performed by Republican Mothers would lead to the following tribute:

"A woman who is skilled in every useful art, who practices every domestic virtue...may, by her precept and example, inspire her brothers, her husband, or her sons, with such a love of virtue, such just ideas of the true value of civil liberty...that future heroes and statesmen, when arrived at the summit of military or political fame, shall exaltingly declare, it is to my mother I owe this elevation."417

Inspired by, enamored of, and grateful to their influences, the families of Abigail Adams and Theodosia Burr Alston revered them as timeless examples of Republican Mothers. John Quincy Adams proved the veracity of Miss P.W. Jackson's belief that future leaders "when arrived at the summit of military or political fame, shall exaltingly declare, it is to my mother I owe this elevation.” Following Abigail’s death, John Quincy declared,

"It is due to gratitude and nation, that I should acknowledge and avow that, such as I have been, whatever it was, such as I am, whatever it is, and such as I hope to be in all futurity, must be ascribed under Providence, to the precepts and example of my mother." 418

In 1799, Aaron Burr replied to a fifteen-year-old Theodosia, who had indicated that she was struggling a bit with her studies of classical languages. Burr encouraged her,

\footnotetext{
${ }^{417}$ Miss P.W. Jackson, “Concluding Address,” The Boston Weekly Magazine, vol 2, issue 1 (Boston: October 29, 1803). Miss Jackson graduated from Susanna Rowson’s Academy in Boston, Massachusetts. Rowson's Academy was one of the prominent female seminaries founded after the Revolution amidst the push for improvements in women's education. See Linda K. Kerber, Women of the Republic: Intellect and Ideology in Revolutionary America, (Chapel Hill: The University of North Carolina Press, 1980).

${ }^{418}$ John Quincy Adams, as quoted in Daniel Wise, The Young Lady's Counsellor (New York: Carlton and Phillips, 1852), 93.
} 
"Let me entreat you not to be discouraged. I know you to be capable of much greater efforts than this will require....Resolve to succeed, and you cannot fail." ${ }^{\text {,19 }}$ Theodosia more than proved that she was capable of overcoming challenges far beyond acquiring proficiency in Latin. During her life, she resolved to succeed time and again, and upon every instance, she prevailed. Swedish painter Karl Frederick von Breda viewed the portrait of her that Burr faithfully carried with him during his European travels. Reacting to the portrait, von Breda exclaimed,

"Good God! Pardon the freedom; but can any man on earth be worthy of that woman? I know not how to estimate her. Such a union of delicacy, dignity, sweetness, and genius I never saw."

Joseph Alston shared von Breda's conviction. He, too, questioned if anyone deserved Theodosia’s heart. His eloquent dedication to her life encapsulates her inestimable worth as a woman who deserves remembrance and respect. After suffering two tragedies within only five months, Joseph divulged his heartbreak to his father-in-law with raw emotion and touching fidelity.

"The talents of my boy, his rare elevation of character, his already extensive reputation for so early an age, made his death regretted by the pride of my family; but though certain of the loss of my not less admirable wife, they seem to consider it like the loss of an ordinary woman. Alas! They know nothing of my heart. They never have known anything of it. Yet, after all, he is a poor actor who cannot sustain his little hour upon the stage, be his part what it may. But the man who has been deemed worthy of the heart of Theodosia Burr, and who has felt what it was to be blessed with such a woman's, will never forget his elevation., ${ }^{421}$

\footnotetext{
${ }^{419}$ Aaron Burr to Theodosia Bartow Burr, January 4, 1799, Matthew L. Davis, ed, Memoirs of Aaron Burr with Miscellaneous Selections from his Correspondence (Memoirs), 2 vols (New York: Harper \& Brothers, 1836), I: 398.

${ }^{420}$ Aaron Burr to Theodosia Burr Alston, June 1809, Matthew L. Davis, ed, The Private Journal of Aaron Burr during his Residence of Four Years in Europe with Selections from his Correspondence (PJAB), 2 vols (New York: Harper \& Brothers, 1838), I: 249.

${ }^{421}$ Joseph Alston to Aaron Burr, February 25, 1813, Memoirs, II: 432.
} 


\section{Legacies and Lessons}

No ordinary women by contemporary or modern standards, Abigail Adams and Theodosia Burr Alston unknowingly emulated the tenets of Republican Motherhood. Abigail Adams reading Common Sense to her young children and taking young John Quincy to view the Battle of Bunker Hill evolved out of her innate concern for the safety of her husband, interest in the future of her country, and immediate proximity to the battlefield. Similarly, Theodosia Burr Alston's lifelong habit of study, encouragement of her husband's public offices, and tireless support of Burr despite sickness and public and private criticism, developed out of natural propensities for learning and a deep affection for her family.

Not cognizant of being Republican Mothers, Abigail Adams and Theodosia Burr Alston represented thousands of women who witnessed the American Revolution and emerging Republic. During an era of upheaval, uncertainty, and crisis, women expressed acute interest in and sensitivity to events surrounding them. They displayed loyalty for their families, community, and nation as they sacrificed personal comfort and safety. Specifically, women suffered absences and deaths of loved ones, shortages, occupation by enemy troops, and a precarious economic, social, and political climate. Furthermore, many women actively wrote letters, occasionally submitted editorials (anonymously) to local papers, attended parades and public speeches, organized boycotts and sewing circles, followed rationing mandates, and protested price gougers.

Most women were not married to one of the most respected American congressmen-turned statesmen-turned second President or distinguished lawyer-turned Senator-turned third vice-President. In this respect, Abigail Adams and Theodosia Burr 
Alston proved that through the agency of motherhood, women could indeed guarantee the stability of the Republic. Thus, Abigail Adams and Theodosia Burr Alston provide identifiable, distinctive, and fascinating models of thousands of Republican Mothers of their time. 


\section{Primary Sources}

\section{Bibliography}

Adams, Charles Francis, ed. Letters of John Adams Addressed to his Wife. 2 vols. Boston: Freeman and Bolles, 1841.

---. Letters of Mrs. Adams, the Wife of John Adams. vol 2. Second Edition. Boston: Charles C. Little \& James Brown, 1840.

Adams Papers. Boston: Massachusetts Historical Society, 1958.

Addison, Joseph and Richard Steele. The Spectator in 8 volumes. London: H. Baldwin, 1797.

Alphonzo. “An Address to the Ladies.” American Magazine. vol 1. issue 4. New York: March 18, 1788. 241-246.

Anonymous. "Female Influence: Being the Substance of an Oration delivered at the Annual Commencement of Columbia College.” NewYork Magazine, or Literary Repository. (May 6, 1795): 304-305

Bloom, Allan, ed. Emile, or On Education, by Jean Jacques Rousseau (1762). New York: Basic Books, Inc., Publishers, 1979.

Butterfield, L. H., ed. Adams Family Correspondence. 8 vols. Cambridge, MA: The Belknap Press of Harvard University Press, 1963-2007.

---. Diary and Autobiography of John Adams. 4 vols. Cambridge, MA: The Belknap Press of Harvard University Press, 1961.

---. The Book of Abigail and John: Selected Letters of the Adams Family, 1762-1784. Boston: Northeastern University Press, 2002.

Cappon, Lester J., ed. The Adams-Jefferson Letters, The Complete Correspondence between Thomas Jefferson and Abigail and John Adams. 2 vols. Chapel Hill: The University of North Carolina Press, 1959.

Crocker, Hannah Mather. Observations on the Real Rights of Women with their Appropriate Duties. Boston: 1818.

Davis, Matthew L. ed. Memoirs of Aaron Burr with Miscellaneous Selections from his Correspondence. 2 vols. New York: Harper \& Brothers, 1836.

---. The Private Journal of Aaron Burr during his Residence of Four Years in Europe with Selections from his Correspondence. 2 vols. New York: Harper \& Brothers, 1838. 
Fordyce, James. Sermons to Young Women. Dublin: W. Gilbert, 1796.

Gregory, Dr. John. A Father's Legacy to His Daughters. Second Edition. London: W. Straham, T. Cadell, J. Balfour, W. Creech, 1774.

Hogan, Margaret A. and C. James Taylor, eds. My Dearest Friend: Letters of Abigail and John Adams. Cambridge, MA: The Belknap Press of Harvard University Press, 2007.

Jackson, Miss P.W. "Concluding Address.” The Boston Weekly Magazine. vol 2. issue 1. Boston: October 29, 1803.

Kline, Mary Jo, ed. The Papers of Aaron Burr. Glen Rock, NJ: Microfilming Corporation of America, 1977.

Makin, Bathshua, An Essay to Revive the [Ancient] Education of Gentlewomen, (London: J. D., 1673.

Masham, Lady Damaris. Occasional Thoughts in Reference to a [Virtuous] or Christian Life. London: A. and J. Churchill, 1705.

Mather, Cotton. Ornaments for the Daughters of Zion, or the Character and Happiness of a Virtuous Woman in a Discourse (1692). New York: Scholar's Facsimiles \& Reprints, 1978.

Mitchell, Stewart, ed. New Letters of Abigail Adams, 1788-1801. Westport, CT: Greenwood Press, 1947.

More, Hannah. Essays on Various Subjects, Principally Designed for Young Ladies. London: J. Wilkie and T. Cadell, 1777.

---. Strictures on the Modern System of Female Education. 2 vols. New York: George Long, 1813.

Murray, Judith Sargent. The Gleaner: A Miscellaneous Production in Three Volumes, by Constantia. Boston: I. Thomas \& E. T. Andrews, 1798.

Poston, Carol H., ed. A Vindication of the Rights of Woman with Strictures on Political and Moral Subjects, by Mary Wollstonecraft (1792). New York: W.W. Norton and Co., Inc., 1975.

Rush, Benjamin. Thoughts upon Female Education, accommodated to the Present State of Society, Manners, and Government, in the United States of America, Addressed to the Visitors of the Young Ladies' Academy in Philadelphia, 28 July 1787, at the Close of the Quarterly Examination. Boston: Samuel Hall, 1787. 
Smith, Dorothy Valentine. “An Intercourse of the Heart’: Some Little-Known Letters of Theodosia Burr.” New York Historical Society Quarterly. vol. 37. no. 1. (January 1953): 41-54.

Steele, Richard. The Tatler, Lubrications of Isaac Bickerstaff in 2 vols. London: John Morphew, 1711.

Wollstonecraft, Mary. Thoughts on the Education of Daughters with Reflections on Female Conduct, in the More Important Duties of Life. London: J. Johnson, 1787.

\section{Secondary Sources}

Akers, Charles W. Abigail Adams: An American Woman. Second Edition. New York: Longman, 2000.

Baker, Paula. "The Domestication of Politics: Women and American Political Society, 1780-1920.” American Historical Review. vol. 89. no. 3. (June 1984): 620-647.

Bloch, Ruth M. “American Feminine Ideals in Transition: The Rise of the Moral Mother, 1785-1815.” Feminist Studies 42 (1978): 101-126.

Cote, Richard N. Theodosia Burr Alston: Portrait of a Prodigy. Mount Pleasant, SC: Corinthian Books, 2002.

Demos, John. Past, Present, and Personal: The Family and the Life Course in American History. Oxford: Oxford University Press, 1986.

De Pauw, Linda Grant and Conover Hunt. 'Remember the Ladies:' Women in America, 1750-1815. New York: The Viking Press, 1976.

De Pauw, Linda Grant. "The American Revolution and the Rights of Women: The Feminist Theory of Abigail Adams.” Legacies of the American Revolution. (1978): 199-219.

Evans, Sara M. Born for Liberty: A History of Women in America. New York: The Free Press, 1989.

Flexner, Eleanor. Mary Wollstonecraft: A Biography. Baltimore: Penguin Books, Inc., 1973.

Geissler, Suzanne. Jonathan Edwards to Aaron Burr, Junior: From the Great Awakening to Democratic Politics. New York: The Edwin Mellen Press, 1981.

Gelles, Edith B. First Thoughts: Life and Letters of Abigail Adams. New York: Twayne Publishers, 1998. 
Gleixner, Ulrike and Marion W. Gray, eds. Gender in Transition: Discourse and Practice in German-Speaking Europe, 1750-1830. Ann Arbor: The University of Michigan Press, 2006.

Gunderson, Joan R. To Be Useful to the World: Women in Revolutionary America, 17401790. New York: Twayne Publishers, 1996.

Hunt, Margaret, et al., eds. Women and the Enlightenment. New York: The Haworth Press, Inc., 1984.

Isenberg, Nancy. Fallen Founder: The Life of Aaron Burr. New York: Viking Penguin, 2007.

Kerber, Linda K. Women of the Republic: Intellect \& Ideology in Revolutionary America. Chapel Hill: The University of North Carolina Press, 1980.

---. "Daughters of Columbia: Educating Women for the Republic, 1787-1815.” In Jean E. Friedman and William G. Shade, eds. Our American Sisters: Women in American Life and Thought. Lexington, MA: D.C. Heath and Co., 1982.

Ketcham, Ralph. "The Puritan Ethic in The Revolutionary Era: Abigail Adams and Thomas Jefferson.” In Carol V. George, ed. 'Remember the Ladies': New Perspectives on Women in American History. Syracuse, NY: Syracuse University Press, 1975.

Levin, Phyllis Lee. Abigail Adams: A Biography. New York: St. Martin’s Press, 1987.

Lomask, Milton. Aaron Burr: The Years from Princeton to Vice-President, 1756-1805. New York: Farrar, Straus, Giroux, 1979.

---. Aaron Burr: The Years of Exile, 1805-1836. New York: Farrar, Straus, Giroux, 1982.

McCulloch, David. John Adams. New York: Simon \& Schuster, 2001.

Norton, Mary Beth. "The Evolution of White Women's Experience in Early America.” The American Historical Review. vol. 89. no. 3. (June 1984): 593-619.

---. Liberty's Daughters: The Revolutionary Experience of American Women, 1750-1800. Boston: Little, Brown, and Company, 1980.

Roberts, Cokie. Ladies of Liberty: The Women Who Shaped Our Nation. New York: Harper Collins, 2008.

Todd, Charles Burr. The True Aaron Burr: A Biographical Sketch. New York: A.S. Barnes \& Company, 1908. 
Wallas, Ada. Before the Bluestockings. London: George Allan and Unwin Ltd., 1929.

Wilson, Joan Hoff. “The Illusion of Change: Women and the American Revolution.” In Alfred F. Young, ed. The American Revolution: Explorations in the History of American Radicalism. Dekalb, IL: Northern Illinois University Press, 1976.

Wise, Daniel. The Young Lady’s Counsellor. New York: Carlton and Phillips, 1852.

Withey, Lynne. Dearest Friend: A Life of Abigail Adams. New York: Simon \& Schuster, 1981. 